\title{
The evolution of mating systems in bark and ambrosia beetles (Coleoptera: Scolytidae and Platypodidae)
}

\author{
L. R. KIRKENDALL \\ Insect Division, Museum of Zoology, and Division of Biological Sciences, \\ University of Michigan, Ann Arbor, MI 48109, U.S.A.*
}

The extraordinary array of mating systems in the Scolytidae and Platypodidae has been largely overlooked by researchers interested in the evolution of sexual behaviour. This paper provides the first overview of reproductive behaviour in this important and widespread group, known to most biologists only by the reputations of tree-killing taxa.

Referred to generally as 'bark beetles', these insects chew egg tunnels inside a variety of (usually dead) plant tissues, though most species are either phloeophagous (breeding in the inner bark of woody plants) or xylomycetophagous (all stages feeding on mutualistic fungi growing on sapwood or heartwood ( In most species, permanent records of many aspects of reproductive behaviour are etched in the host; in many, engravings reveal female fecundity, eggs sired per male, hatching success, and offspring survivorship. Each gallery arm represents a good portion of a given female's lifetime reproduction, but in many species females commonly re-emerge to reproduce in one or two additional sites.

In most species of bark beetles, each female initiates her own gallery, to be joined later by a male. These monogynous gallery systems are associated with mating systems defined by how long males stay with females: in a few species, males seldom if ever join females under the bark; in the vast majority of species, males stay for part or all of the oviposition period then leave to seek other mates; and a few groups exhibit permanent monogamy, in that both sexes die in their only gallery system. While these patterns emerge from an overview of the world scolytid fauna, the length of male residency has seldom been quantified, and the costs and benefits associated with male mating strategies have not been measured for any bark beetle.

Male-initiated monogyny is uncommon in Scolytidae, though the rule in Platypodidae; all instances of which I am aware are summarized from a phylogenetic perspective.

Inbreeding polygyny with highly biased sex ratios has arisen at least seven times in Scolytidae. These taxa are usually characterized by males being dwarfed, flightless, and uncommon. Sex determination is known for only a few examples, but both haplodiploidy and diplodiploidy have been reported.

Multiple origins of harem polygyny (otherwise rare in invertebrates) add an exciting dimension to the comparative and experimental study of scolytid mating systems. In harem polygynous taxa, males initiate gallery construction. I summarize what little can be learned from the literature about the fine structure of harem polygynous mating systems in bark beetles, and the problem of measuring reproductive success. Data on the nature of harem polygyny in Pityophthorus lautus are presented, illustrating (a) the fluidity of harems; (b) that average eggs laid per gallery arm is relatively unaffected by harem size, but strongly influenced by resource quality; (c) that male egg-gain is strongly correlated with territory quality (a consequence of (b) above); and (d) the temporal patterning of immigration and emigration and its effects on gallery system sex ratios.

The second half of this paper is a discussion of the evolution of bark and ambrosia beetle mating

*Current address: Zoological Institute, University of Oslo, P.O. Box 1050 Blindern, Oslo 3 Norway. 
systems, emphasizing sexual selection and the role of resources. Male, residence is interpreted as postcopulatory guarding preventing sexual liaisons with wandering males. Operational sex ratio, cncounter rate, synchrony of breeding, ejaculate competition, and spatiotemporal distribution of resources are discussed as evolutionary forces moulding scolytid and platypodid male postmating behaviour. The natuse of male mate competition is reviewed. The paucity of information on mate behaviour in gallery systems is mentioned; whether or not males significantly aid females is not known. Three hypotheses are presented for why females re-emerge, a feature which strongly alfects operational sex ratios. Finally, I summarize features of bark beetle existence predisposing them to the evolution of post-inseminative guarding.

Male-initiated monogyny presents a puzzle. I propose that most uncontested examples can be explained by monogyny re-evolving from (male-initiated harem polygyny, and I present an argument for the evolution of harem polygyny leading to the development of male gallery initiation.

The evolution of harem polygyny in birds and mammals has attracted considerable attention. The Verner Willson Orians polygyny threshold model is discussed with respect to bark beetles in general and $P$. lautus in particular. Resource quality is a major factor in $P$. lautus harem dynamics: the cost to lemales of joining harems is apparently slight compared to benefits accrued from moving into sites with higher quality inner bark.

Female-biased adult sex ratios have been suggested to lead to harem polygyny, and literature and original datit pertinent to this hypothesis are examined.

The geometric constraints model, based on the polygyny threshold concept but tailored to bark bectles, is proposed to account for the failure of most species to evolve harem polygyny, and testable predictions are derived that interrelate breeding systems, habitat quality, and progeny size.

The colution of inbreeding is briefly corered, and two routes to inbreeding polygyny are suggested

KEY WORDS: Mating systems harem polygyny - monogamy - inbreeding - Scolytidae Platypodidae bark beetle - ambrosia beetle resource quality Pityophthorus.

\section{CONIENTS}

Introduction

Mating systems and their classification

Biology of bark and ambrosia beetles

Gallery system construction.

Pheromones.

Phylogeny

Description of mating systems

Female-initiated monogyny

Tachygamy .

Bracliygamy

Monogamy .

Discussion

Male-initiated monogyny

Bothrosternini

Phlocotritini

Phloeosinini.

Scolytini

Ctenophorini

Scolytoplatypodini

Xyloterini

Corthylini

Harem polygyny

Lesser known cases

Describing harem polygyny

Measuring reproductive success

The nature of harem polygyny in Pituophthons lautu

Inbreeding polygyny

Sex ratio control

Inbreeding in Dendrostomus mican

Wolution of bark and ambrosia beetle mating systems . . . . . . . . . . . . . . 324

'The evolution of male residence

Costs of not guarding

Why do bark beetles re-emerge?

Polyandry

The nature of male-male competition

Conclusions.

The exolution of male-initiated monogyny 


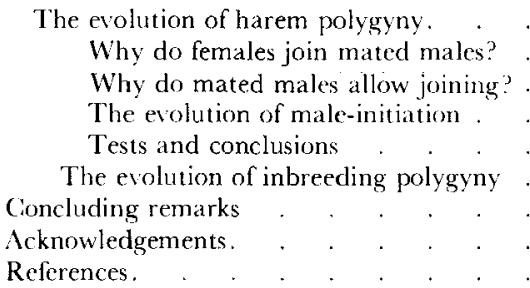

\section{INTRODUCTION}

\section{Mating systems and their classification}

Bark and ambrosia beetles of the Scolytidae and Platypodidae form a welldefined grouping of roughly 7000 species world-wide. The deserved notoriety of a handful of devastatingly destructive taxa belies the more positive contributions of the vast majority of species, which are primary decomposers of dead woody tissue. While intense research efforts on the biology of tree-killing and wood-staining species have yielded a plethora of useful and exciting information on many facets of their biology (on life-history parameters, chemical and sonic communication, and interactions with host trees, to name just three), what we have learned of these pest species is frequently not representative of the nature of bark and ambrosia beetles as a whole. Hidden away in a thicket of primarily taxonomic and distributional papers plus a small number of mostly larger works devoted to presenting natural history of scolytoids of particular geographical regions, is the fact that in this single offshoot from an ancient protoweevil stock one can find an astonishing array of habits. Multiple origins of mating systems otherwise rare in insects-various forms of monogamy and harem polygyny - are an especially exciting feature of this group, though the very existence of these mating systems in bark and ambrosia beetles has hitherto escaped the notice of most evolutionary biologists interested in sexual behaviour.

In recent times, a growing appreciation of the significance of reproductive conflict of interests between the sexes has heightened interest in mating behaviour, especially in its organization in space and time. Three interrelated causal factors predominate in models dealing with mating systems: the abundance, quality and spatial and temporal distribution of essential resources; the ratio of receptive females to sexually active males ('operational sex ratio': Emlen, 1976; Emlen \& Oring, 1977); and the synchrony of breeding. The nature of essential resources dictates the degree to which males will be able to control female access to resources and also determines the spatial and temporal distribution of females. The spatial and temporal distribution of potential mates is one factor affecting the operational sex ratio (another being differential mortality due to differing male and female juvenile or adult behavioural or developmental 'strategies'). The synchrony or asynchrony with which females reproduce, coupled with the nature of essential resources, also directly affects the operational sex ratio; for example, increasing asynchrony plus patchy resources easily located by males leads to an increasingly male-biased operational sex ratio at resource sites where mating takes place. The interrelationships of these factors, as they apply to bark beetle mating systems, will be discussed below.

Reviews of mating systems have been concerned primarily with birds and 
mammals, a bias reflected in the various attempts at constructing 'inclusive' categorizations and definitions (for example, the scheme of Emlen \& Oring (1977) simply doesn't fit most insects). Delimitations of mating systems have centered on, (a) sexual differences in the variance of reproductive success, (b) the degree of pairbonding and relative parental expenditures, (c) the number of matings typically enjoyed by breeding members of each sex, or (d) the manner of mate acquisition (i.e. whether males 'control' groups of females or attract females to a defended resource).

Classification of scolytoid mating systems is made easier by the fact that we can ignore (d); all polygynous bark beetles exhibit 'resource defence' as opposed to guarding mobile groups of females. Sexual differences in the variance in reproductive success (a) are extremely difficult to measure (e.g. Payne \& Payne, 1977), and hence cannot readily be used.

Using (c)--numbers of matings-exclusively would obscure the interesting and significant variability in scolytid mating systems. With few possible exceptions (Trägårdh, 1930, Hylastes; Brown, 1961c, 1962a, the platypodid genus Doliopygus) females (and of course males) of outbreeding species copulate more than once, often with different partners, e.g. species of Dendroctonus (Reid, 1958; Yu \& Tsao, 1967), Tomicus (Salonen, 1973 and refs), Phloeotribus (Wilson, 1909), Scolytus (Fisher, 1931; Goeden \& Norris, 1965; Beaver, 1966a ; Rudinsky, Vallo \& Ryker, 1978), Ips (Chararas, 1962; Balogun, 1970; Schmitz, 1972; Gouger, Yearian \& Wilkinson, 1975; Witanachchi, 1980), Pitypogenes (Schwerdtfeger, 1929), Pityokteines (Chararas, 1962), Cryphalus (as Taenioglyptes: Wood, 1954a, Chamberlin, 1958), Procryphalus (Wood, 1954a; Petty, 1977), Trypophloeus (Wood, 1954a, as Cryphalus; Petty, 1977), Trypodendron (Fockler \& Borden, 1972, and Conophthorus (Schaefer, 1972). Nevertheless, females of most species may be effectively monogamous, or nearly so, for a given brood - all the offspring she produces in one

Table 1. Gallery system and mating system terminology used in this paper

\begin{tabular}{|c|c|c|}
\hline Gallery system & & Mating systems associated \\
\hline \multirow[t]{4}{*}{$\begin{array}{l}\text { Monogynous: The work of one } \\
\text { female }\end{array}$} & Tachygamy: & $\begin{array}{l}\text { No lasting pair-bonds formed, some short-term } \\
\text { guarding may exist }\end{array}$ \\
\hline & Brachygamy: & $\begin{array}{l}\text { Exclusive pair-bonds of variable duration are } \\
\text { formed, but males usually do not stay for an } \\
\text { entire oviposition period }\end{array}$ \\
\hline & Monogamy: & $\begin{array}{l}\text { Males remain until females finish ovipositing. } \\
\text { When re-emergence and re-attack occur, Serial } \\
\text { Monogamy results. Where both sexes normally } \\
\text { die in their only gallery system, Permanent } \\
\text { Monogamy occurs }\end{array}$ \\
\hline & Inbreeding polygyny: & $\begin{array}{l}\text { Mating takes place in the natal nest (formed by } \\
\text { a single mother), females are usually inseminated } \\
\text { by their less-numerous brothers }\end{array}$ \\
\hline \multirow[t]{2}{*}{$\begin{array}{l}\text { Polygynous: The work of one to } \\
\text { many females }\end{array}$} & Harem polygyny: & $\begin{array}{l}\text { Commonly, at least some males are } \\
\text { simultaneously paired with more than one } \\
\text { female. In Bigynous species, most males are } \\
\text { mated to two females. Males usually stay until al } \\
\text { their females finish oviposition? }\end{array}$ \\
\hline & Colonial: & $\begin{array}{l}\text { Several to many females and more than one male } \\
\text { are found in a single gallery system }\end{array}$ \\
\hline
\end{tabular}


gallery system. Female insects store sperm, and often sperm from the most recent copulation takes almost complete precedence in fertilizing eggs. Ejaculate competition has not yet been studied in bark beetles: for weevil examples (exhibiting last-male precedence) see Jaynes \& Godwin (1957), Bartlett, Mattix \& Wilson (1968), Ferrer \& Hower (1975). References for other insects can be found in Parker (1970), Boorman \& Parker (1976), and Walker (1980). The fact that some females mate with more than one male may be offset by the probable occurrence of a high level of sperm displacement with each copulation. Thus, categorizing mating systems by number of matings may or may not reflect the quantity in which we are most interested: variation in reproductive success and how it differs between the sexes.

To minimize ambiguity, I propose separate terms be used to describe gallery systems and mating systems (Table 1); much confusion arises from past failures to separate the two. Gallery systems (sometimes referred to as nests) are distinguished by the number of females involved in their construction, and can be so described without any implications about the nature of pair-bonding. Mating systems are classified here by how long males stay with females after copulation.

'Monogamy', previously used to cover all monogynous ('one female') systems by many authors, is herein reserved for mating systems in which males stay during the entire oviposition period for one brood. 'Brachygamy' ('short marriage'; after Selander, 1972) will be used to refer to species in which shorter pair-bonds are formed. 'Tachygamy' ('rapid marriage': intended, albeit awkwardly, to mean pair-bonds of very brief duration) is coined to describe mating systems in which no lasting pair bond is formed-males that stay at all after copulation leave before oviposition gets underway. In inbreeding species, sibling-mated females construct gallery systems alone. 'Spanandrous' (lit., 'scarce males') has been used by such authors as Balachowsky (1949), Hamilton (1967) and Beaver (1977, 1979b, c) to refer to the strongly biased sex ratios associated with inbreeding species, and 'spanandry' used for the resultant breeding system. I feel 'inbreeding polygyny' is a more direct and self-explanatory term for a mating system.

Polygynous systems - those built by more than one female - can contain one male, in which case they are termed 'harem polygynous', or if several males are present the mating system can be called 'colonial polygyny'. (Although 'polygyny' is sometimes defined to only include cases where males are simultaneously paired with more than one female, behavioural ecologists often use the term more broadly, to include all examples of males mating with more than one female regardless of whether the multiple pairings were simultaneous or sequential.)

The terms employed in this paper (Table 1) apply to the usual behaviour in the populations being discussed.

\section{Biology of bark and ambrosia beetles}

The Scolytidae and Platypodidae are curculionoid beetles in which the females spend their reproductive lives inside their breeding material. Scolytoids have evolved forms which take advantage of every plant tissue (including leaves, e.g. Cactopinus depressus Bright in Yucca: Bright, 1967). Most feed and reproduce in the inner bark, or in fungus-lined tunnels in (usually) sapwood (so-called 'ambrosia beetles'), of dead woody plants. Feeding in dead inner bark-phloeophagy 
(terminology from Schedl, 1958)-is probably the primitive behaviour of these beetles (Schedl, 1958).

The ambrosia feeding mode - xylomycetophagy-has evolved numerous times in this group (Fig. 1), and quite intricate mutualistic relationships have developed between these beetles and the fungi and bacteria with which they are associated (Barras \& Perry, 1975; Norris, 1975, 1979; Kok, 1979). Wood-feeding by larvae is uncommon but has arisen in a variety of lineages (e.g. Nobuchi, 1969, 1971, 1972). Furthermore, in some groups such as Phloeosinus, Hylesinus, and some Scolytus, older larvae may feed largely or wholly in the sapwood when in thin-barked material or as a regular habit, depending on the species. Pith-feeding (myelophagy) can be found in a variety of taxa. Beaver $(1977,1979 \mathrm{c}$ ) classified such species as 'herbiphagous', along with beetles feeding in stems of non-woody plants and in leaf petioles; nutritionally, pith may be closer to inner bark (Merrill \& Cowling, 1966), and a number of phloeophagous species utilizing twigs also feed or breed in pith. Most Coccotrypes (including Poecilips Schauf.) feed in fruits and seeds (spermatophagy), rarely including those of gymnosperms (Browne, 1961 a), a habit infrequently encountered in other groups. A smattering of species breed in such aberrant habitats as stalks of fallen leaves (Beaver, 1979a, b) or stems and roots of herbs, e.g. Hylastinus (Balachowsky, 1949), Coleobothrus and Aphanarthrum (Israelson, 1980), Dendrocranulus, and a few Hypothenemus plus one Chramesus (Wood, 1982).

'Bark beetle' is used frequently to refer to Scolytidae as a whole, including 'ambrosia beetles' (which are often called 'shot-hole borers', 'pinhole borers', or 'timber borers'). 'Ambrosia beetles' includes the xylomycetophagous members of both Scolytidae and Platypodidae.

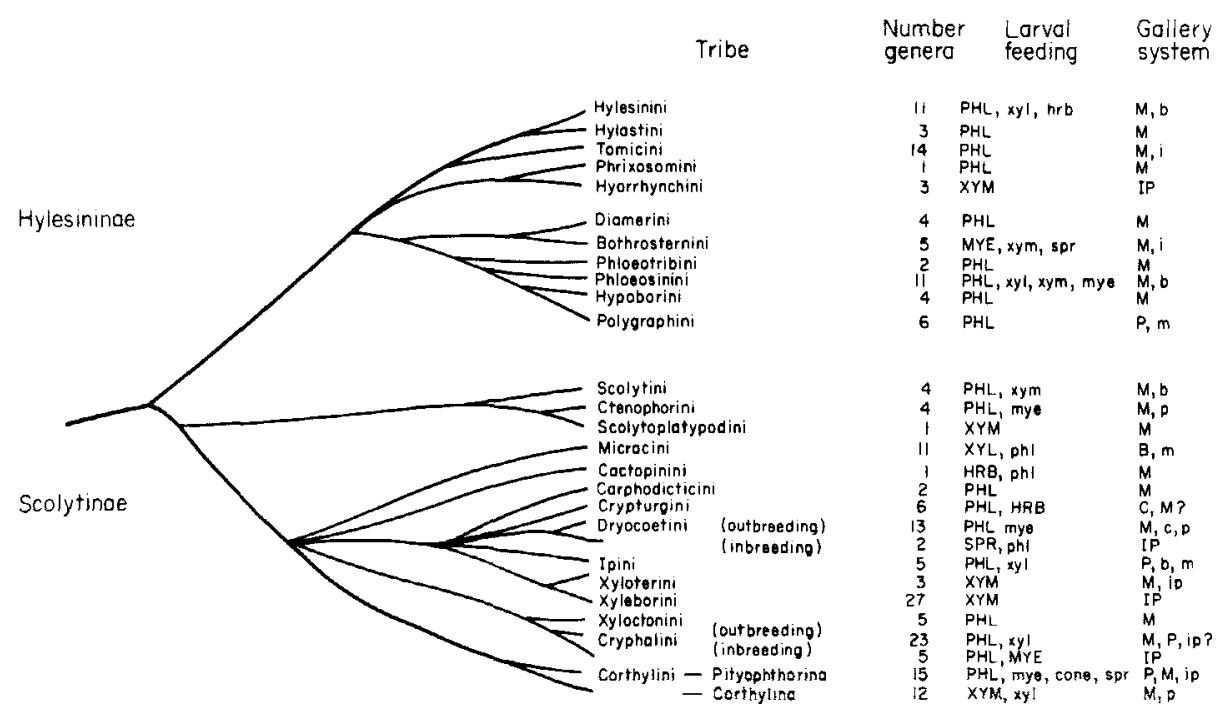

Figure 1. Phylogenetic distribution of feeding habits and breeding systems in Scolycidae. Phylogeny and number of genera per tribe based on Wood (1978, 1980, 1982 . Predominant larval feeding modes and predominant breeding systems are given in upper case, uncommon ones in lower case (PHLphloeophagous; XYL-xylophagous; XYM-xylomycetophagous; SPR-spermatophagous; MYEmyelophagous; HRB-herbiphagous; $\mathrm{M}$-monogynous; IP - inbreeding polygynous; $\mathrm{P}$-harem polygynous; B-bigynous; $\mathrm{C}$ - Colonial $)$. 
Gallery system construction

The most striking activity of bark beetles is their gallery systems, and these show considerable variability. Illustrated descriptions of the types of gallery systems can be found in most general sources dealing with Scolytidae (e.g. Swaine, 1918; Chamberlin, 1939, 1958; Blackman, 1922a; Balachowsky, 1949; Chararas, 1962 ; Bright \& Stark, 1973) or in works devoted specifically to gallery system form (Kabe, 1954, 1955) or function (Trägårdh, 1930). I will give only a brief summary here. The typical scolytid gallery system consists of one or more gallery arms with periodic broadly U-shaped niches cut along either side, each niche getting a single egg packed in with boring dust mixed with what is probably a salivary secretion. These arms are chewed out by the female; males that stay during gallery construction remain blocking the entrance hole, occasionally leaving their post to copulate, feed, or remove accumulations of frass (boring dust mixed with excrement). In species in which males stay, the entry way leads to a central enlarged area ('nuptial chamber') or a short spur ('turning niche'). Such a feature is commonly missing in species in which males apparently never stay (e.g. Strombophorus, many Scolytus) or in galleries of polygynous species that are wholly constructed by a female (e.g. in Ips grandicollis, reported by Wilkinson (1964) and by All \& Anderson (1972); and in Pityophthorus lautus and Ips acuminatus (pers. obs.)). Monogynous gallery systems usually include either one longitudinal (i.e. parallel to the long axis of the branch or stem) gallery arm or two transverse arms leading away in opposite directions from the nuptial chamber or the base of the entrance tunnel. In some monogynous taxa, including the primitive phloeophagous platypodid Mecopelmus Blackman as well as such highly derived forms as many phloeophagous Cryphalini and a number of Pityophthorus species that breed in inner bark of twigs and small branches, the female chews out an irregular cavity rather than a gallery arm-the 'cave-type' gallery system; eggs are laid in irregular masses at any part of the cave or in egg niches or grooves at its periphery.

Harem polygynous systems normally consist of one or several gallery arms leading away from the central nuptial chamber; it has commonly been assumed that each arm is the sole work of one female. Arms may be arranged longitudinally (some Ips), transversely (Pityokteines, for example) or radiate outward in a star-like configuration (as in many Pityophthorus).

The foregoing descriptions refer mainly to phloeophagous taxa. In xylophagous species, arms tend to run either directly into the wood or in the sapwood parallel to the long axis of the branch. Pith-breeders make one or two arms up and down the pith. Xylomycetophagous beetles tunnel into the wood and construct branches following around growth rings or make several parallel branches going straight inward, or, rarely, longitudinal branches.

Most gallery systems engrave the wood of host material. In phloeophagous species, the nuptial chamber and arms usually lie at least partly in the outermost sapwood, and long after the beetles' tasks are completed one can read much of their history from the 'writing' on the wood: the number of arms that were made, arm length, number of eggs laid (when each niche receives only one egg), number of larvae hatching (if larval feeding grooves the wood), and so forth. For the bark beetle researcher, this is certainly one of the most useful and important features of scolytid biology.

In many if not most species, both sexes participate in more than one gullery 
system. Such 're-emergence' has been reported to be a regular phenomenon for most non-xylomycetophagous outbreeding species that have been carefully studied, e.g. species of Alniphagus (Borden, 1969), Dendroctonus (Swaine, 1929; Massey \& Wygant, 1951; Smith, 1961; Wood, 1963; Coster, 1970; Cooper \& Stephen, 1978; Coulson et al., 1978), Pseudohylesinus (McGehey \& Nagel, 1969), Tomicus (=Blastophagus; Salonen, 1973), Polygraphus (Simpson, 1929; Reid, 1955) Ips (Reid, 1955; Thomas, 1961; Cameron \& Borden, 1967; Schenk \& Benjamin, 1969; Balogun, 1970), Pityogenes (Reid, 1955), Pityophthorus (pers. obs.), and Pseudopityophthorus (Rexrode, 1969). In most of these studies it was also shown that re-emerging adults can reproduce again. The examples above are holarctic species; Browne (196la: 42) believes that in the humid tropics, most species may participate in only one gallery system. Nevertheless, reports that some parents reemerge and re-attack are so frequent, that the behaviour should be assumed to exist unless there is cvidence to the contrary. Many non-xylomycetophagous outbreeding females probably produce more than one brood before dying, though usually all in one summer. It seems highly likely, though, that individual females in uncrowded high quality resource situations expend their entire reproduction in one gallery. With the exception of species breeding in material which can support only a few progeny (such as leaf petioles and small pine cones) it is probably rare for a female to cut more than three or four gallery arms.

\section{Pheromones}

No general description of scolytid biology can be complete without mention of pheromone systems, though this paper will largely ignore that fascinating and complex field of study. Much research is devoted to the elucidation of scolytid pheromone systems (e.g. reviews by Borden, 1974b; Borden, VanderSar \& Stokkink, 1975; Vité \& Francke, 1976; Birch, 1978). The use of a combination of beetle- and host-derived odours to locate conspecifics may be primitive in scolytoids, as it apparently occurs throughout these two families with only a few exceptions (Borden et al., 1975). The individual initiating gallery construction releases components of the pheromone 'bouquet' which attract conspecifics of the opposite sex and always, though often to a lesser extent, members of the same sex. In monogynous systems, it is usually the female which initiates gallery construction (but see 'male-initiated monogyny' section below). In harem polygynous species, males are the pioneer sex. The initiating sex is almost invariably the initial pheromone-producing sex (the only known exception is Scolytus scolytus: see Borden \& King, 1977, also Beaver, 1966a). Although pheromones play an important role, they are effects (sensu Williams, 1966) and not causes in mating system evolutionwhich is why they are given short shrift in this paper. The lability of pheromone systems in cvolutionary history can be seen in the cosmopolitan genus Phloeosinus Chapuis. Most species are called 'monogamous' or said to have 1-armed gallery systems (Blackman, 1942; Chamberlin, 1958; Schedl, 1960; Browne, 1961a; Bright \& Stark, 1973; Wood, 1982), and for three North American, one European, and one South-East Asian species it is known that females initiate gallery construction (DeLeon, 1952; Chararas, Juster \& Balmain-Oligo, 1968; Bright \& Stark, 1973; Beaver \& Browne, 1978) and thus presumably are the pheromoneproducing sex. The European Ph. thuyae Perris and bicolor Brul. are regularly bigynous (see Table IV); males initiate gallery construction and produce mate- 
attractants (Chararas, 1962, 1969). It seems more likely to me that the ancestor(s) to these two species adapted to a resource capable of supporting polygyny and evolved a different male strategy as a result, than that the gender which initiates galleries had changed and polygyny followed.

\section{Phylogeny}

The phylogeny of scolytoid beetles has been treated most recently by Schedl (1959, 1960, 1961, 1962, and Browne (1961a) implicitly, explicitly by Lekander (1968, 27 genera), Nobuchi (1969, about 100 genera; see also 1971), and Wood $(1978,180$ genera; see also 1973, 1982). Only the latter two authors treat the group on a world level, and as Wood's treatment (1978) is the most comprehensive in numbers of taxa considered and of characters examined, I have adopted it here. Wood's classification reflects the general trends in larval characters reported by Lekander. Despite working independently of each other, there is remarkable concordance between the schemes of Nobuchi and Wood; the differences do not seriously affect the conclusions in this paper. The phylogenetic tree presented here (Fig. 1) represents the discussions of characters in Wood (1978) (cf. Wood, 1982: $43)$.

\section{DESCRIPTION OF MATING SYSTEMS}

\section{Female-initiated monogyny}

Table 2 presents information on the nature of monogyny in bark beetles. For each species included I have indicated (a) the sex initiating galleries, (b) when males usually leave (or if they die in the gallery system), (c) whether or not it is claimed that females re-emerged and excavated one or more additional galleries elsewhere, and (d) the feeding behaviour of the larvae. Included are species for which it is clearly stated that the male remains in the gallery system after copulation, or that he definitely does not stay. I have not included most accounts that simply say a genus or species is 'monogamous' since it is usually not clear whether this is a description of the gallery system form, or of the fact that the system is excavated by a single female, or of pairing behaviour. I have tried to give representative examples for each tribe (see also Fig. 1), but not a complete catalogue of occurrences of this type of mating system. However, as can be seen from the references, examples have been drawn from around the world. This survey reveals three basic male strategies with regard to pair formation.

\section{Tachygamy}

In tachygamous systems, there is no prolonged association between males and females; male reproductive success is maximized by copulating with as many different females as possible. Examples include Alniphagus aspericollis, Strombophorus, Scolytus rugulosus, S. quadrispinosus, Conophthorus resinosae, and possibly Pityophthorus orarius (refs in Table 2). Beaver (1966a), studying Scolytus multistriatus in Ulmus procera in England, found that males did not stay long, if at all, and concluded that males were essentially 'polygamous'. Bartels \& Lanier (1974) working with an introduced population of the same species in Ulmus americana in New York, observed similarly that "males may enter the female gallery but their visits are 
short, and few are found in dissected galleries". In contrast, my notes on sampled galleries from a $4-\mathrm{cm}$ diameter broken branch of a small-leaved exotic Ulmus in Ann Arbor, Michigan, in late August, 1978 paint a different picture. The 10 gallery systems I dissected ranged from 8 to $36 \mathrm{~mm}$ in total length and had from 20 to 42 niches, and $25100^{\circ}$ (in two galleries) of the viable eggs present had hatched to larvae. Three galleries had only a dead female, two a live female, one a dead male, one a live male, one a dead male and a live female, one a live male and a live female, and one a live male and a live female plus a dead female in a short, niche-less arm. Thus, $50^{\circ}$ of these galleries (in all of which gallery construction was at lcast half over) had a male present. Such mating system variability among populations is rare in insects, and this instance deserves further study if my limited Ann Arbor observations are representative.

Alniphagus aspericollis breeds in inner bark of weakened trees or slash of red alder, Alnus rubra Bong. in the Pacific Northwest. Of 61 galleries dissected during the initial, 3-day flight, 40 had two adults (and one had three). By 1 week later, males had apparently left (Borden, 1969: Table 2). Little more is known of the other examples of tachygamous species than what is given in the table.

Perhaps those species that appear to be colonial should be included in this category, but it is not known if males form pair-bonds with individual females or not. I refer here to Cyrtogenius brevior (Egg.) and Crypturgus species. In the former, a phloeophagous Fijian bark beetle, gallery systems are many-branched with several adults in each branch; 20 males and 32 females were taken from 11 to 12 galleries (Beaver, 1976). Congeners are said to be monogamous and phloeophagous or xylophagous, but construct a variety of types of gallery systems (Browne, 1961a, as Carposinus perakensis (Schedl) ; Browne, 1963a; Roberts, 1976). Crypturgus are usually (though not always) inquilines of much larger bark beetles, beginning their galleries from the nuptial chamber or gallery arm of their hosts. Crypturgus individuals are among the smallest of scolytids (around $1 \mathrm{~mm}$ long). Their size, combined with the fact that they usually breed completely in the inner bark of material also being utilized by larvae of other bark beetles, makes study of their habits extremely difficult. Crypturgus cinereus Herbst galleries frequently branch and intersect other arms, so that one finds an indescribable network of galleries (Chararas, 1962). Male behaviour is not mentioned, but it seems possible that males may not be able to maintain exclusive sexual access to females in such a system, and therefore direct their efforts towards maximizing number of matings. Blackman \& Stage (1918: 55-59) comment on the seemingly colonial nature of $C$. pusillus Gyll., and lean toward the view that the groups of six to 30 or more individuals represent numerous beetles of each sex, and that "relations in these colonies are more or less indiscriminate".

\section{Brachygamy}

Into the second category fall those taxa in which males stay for some part of the oriposition period. Females thereby gain the potential benefits of having a male blocking the entrance to the gallery system and expelling frass for at least part of the time the females are laying eggs. Little is known of the details of such a system, for any scolytid. In fact, for most of the species listed in Table 2, it is not really known that males do not stay for the entire oviposition period. For example, in many Dendroctonus species (Wood, 1963) and Hylurgus ligniperda (Chararas, 1962) males are frequently or always walled-off from working females by resinous frass. 


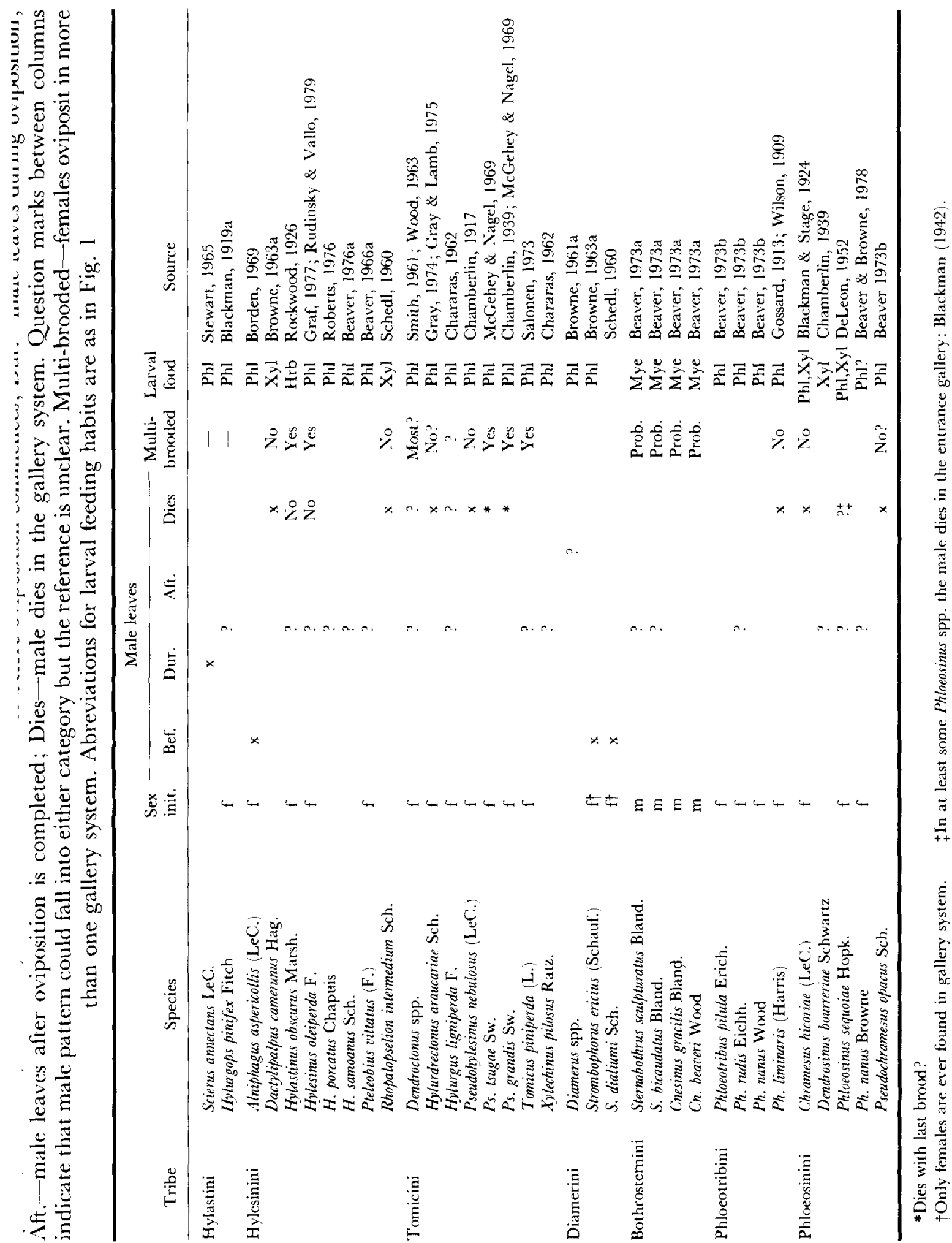




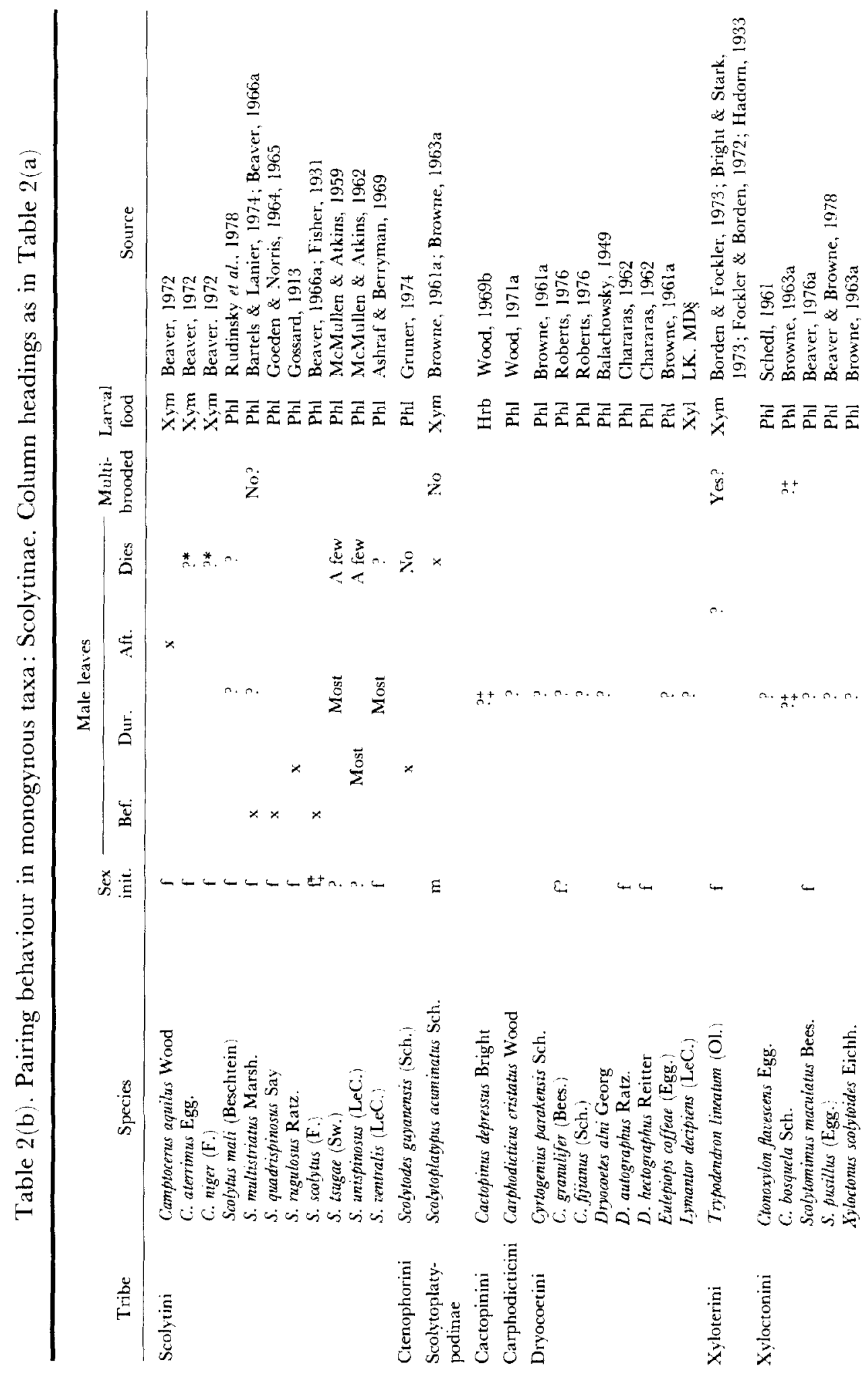




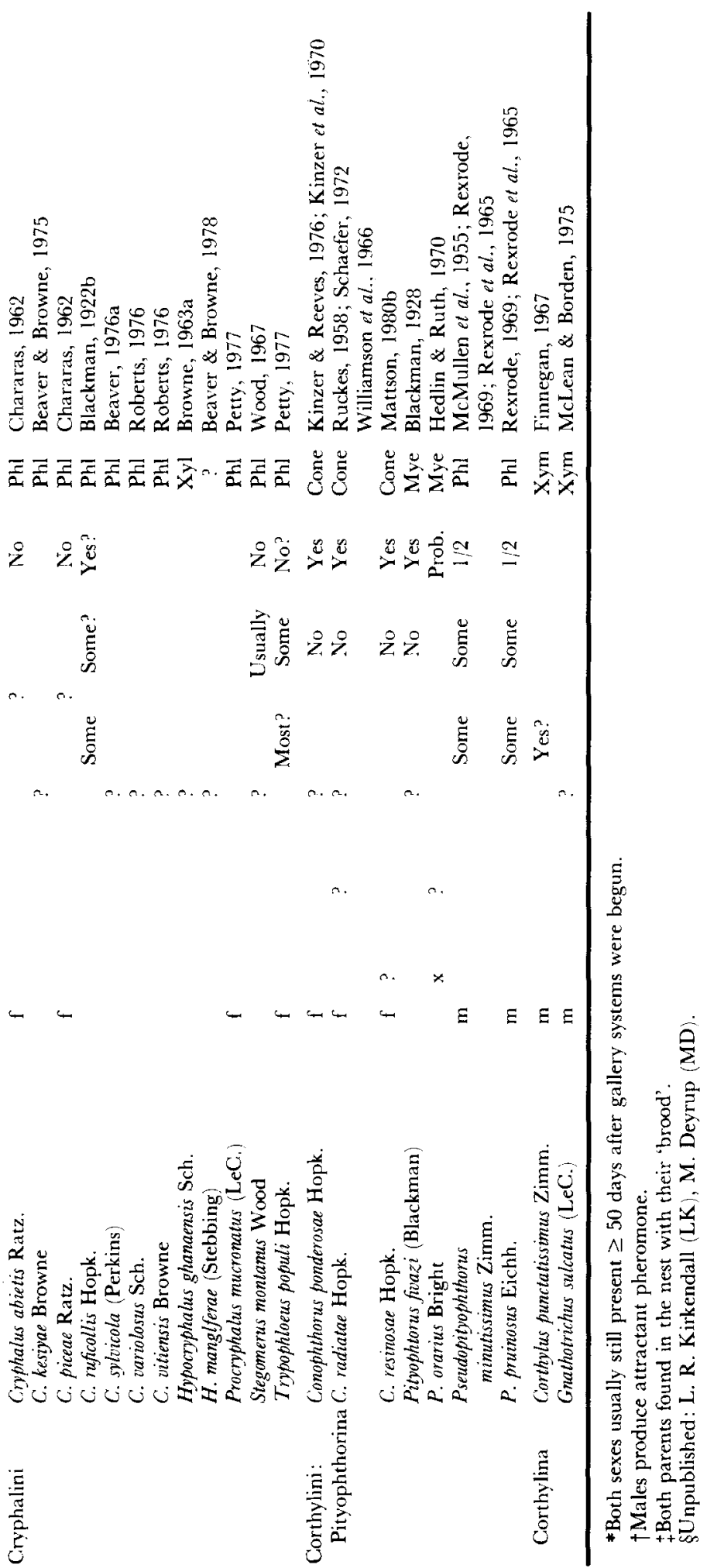


How long males of these Tomicini remain in that condition has apparently not been directly determined; even separated males may be able to prevent direct access to females by remaining in the gallery arms. Separation of males from females also occurs in some ipine and corthyline polygynous species (e.g. Blackman, 1919a; Trägårdh, 1930).

McMullen \& Atkins $(1959,1962)$ examined galleries of known age for Scolytus tsugae and S. unispinosus. Males leave systems before females in both species, with galleries over 20 days old seldom containing two live adults. When only one live adult was found, it was 'usually' a female. $\Lambda$ s in most of the species in Table 2 , it is not indicated how long Tomicus piniperda males stay. Salonen (1973) docs indicate, though, that inseminated females can reproduce normally in the complete absence of males or in a situation with more females than males present in a given section of trunk (Salonen 1973, tables 19, 20).

\section{Monogamy}

The third category includes those species in which males usually stay for an entire reproductive bout; it can be subdivided (though not with complete success) into (1) those species in which males often leave after oviposition in their gallery has stopped (to participate in further pairing?), and (2) those in which males normally die in their first and only gallery system-plugging the entryway with their bodies.

Few species arc known to fit this category. Diamerus are large, stout phloeophagous beetles most commonly associated with Urticaceae and Moraceae. The genus is said to be monogamous, and "both parents play their part in the care of the nest and of the young brood". No mention is made of male re-emergence or death (Browne, 1962a: 57). Four Comptocerus species studied by Beaver (1972) breed in branches and stems; the larvae are xylomycetophagous. Data from dissected gallery systems (Beaver, 1972, table II) suggest that aquilus males probably leave after gallery construction or oviposition, as do most females; aterrimus and niger parents were still present among the larvae, pupae, and teneral adults when the gallery systems were dissected 50 or more days after the start of attacks. Males of another ambrosia beetle, Trypodendron lineatum, are also still present 7 weeks after gallery initiation (Borden, 1974a), but in this species parents at least sometimes re-emerge (Borden \& Fockler, 1973; cf. Hadorn, 1933). Interestingly, Hadorn observed that most galleries constructed by reattacking females contained no male partners; spermathecae of these females had residual amounts of live sperm suggesting reinsemination was not necessary for constructing their second gallery system. Males regularly die plugging their only gallery system in some Phloeosinus species according to Blackman (1942) though Browne (1961a) does not mention such behaviour in Phloeosinus he has collected in Malaya; I have observed the phenomenon in another phloeosinine, Chramesus hicoriae, which breeds in the inner bark of small dead hickory (Carya) branches. Beaver (1973b) records dead males blocking entryways in a third member of the tribe, Pseudochramesus opacus. Phloeotribus liminaris males also may commit themselves to one gallery system (Wilson, 1909). Chamberlin (1917) states that Pseudohylesinus nebulosus males die blocking. McGehey \& Nagel (1969) report that Ps. lsugae and Ps. grandis females often cut more than one gallery, and males may die in the entrance to the last gallery systems. About one-half of Pseudopityophthorus minutissimus and Ps. pruinosus females re-emerge, and males die blocking some gallery systems (Rexrode, 
Kulman \& Dorsey, 1965; Rexrode, 1969; see also McMullen, King \& Shenefelt, 1955).

Males of the ambrosia beetle Scolytoplatypus acuminatus commit themselves to one gallery system (Browne, 1961a, 1963a), but it is not known if this is also true of the xylomycetophagous corthylines (see Table 2). Platypodidae parents (except some Coptonotinae: Wood, 1973) are thought to make only one gallery system (Browne, 1961a) and all authors consider the entire group (except some Coptonotinae) to be monogamous (e.g. Browne, 1961 a; Schedl, 1972). In at least some platypodids, the last five joints of each leg (the tarsi) usually break off early in the nest construction period making it impossible for the parents to walk on any vertical surface ever again (Roberts, 1960).

\section{Discussion}

Clearly, male strategies in 'monogamous' bark beetle taxa are little understood. Males have never been marked individually and followed in nature for any species in which males stay, so we do not know how often individual males move around or are displaced by rival males, or what behavioural or morphological characteristics make for a 'successful' male. Nevertheless, from what we do know, it is plain that considerable variation exists among (and possibly within) species, and that sexual selection must have quite different effects at the extremes. It is also possible that forms of male parental care await discovery in those species in which males totally commit their reproductive effort to one female.

\section{Male-initiated monogyny}

Male-initiated monogyny is unusual in scolytids but is the rule in Platypodidae. Below, I briefly describe its occurrence in Scolytidae, along with what is known about the presumed near relatives of male-initiated monogynous taxa.

\section{Bothrosternini}

Males initiate gallery systems in Sternobothrus sculpturatus, S. bicaudatus, Cnesinus gracilis, and $C n$. beaveri, and during egg-laying they remain in the entrance. These species breed in pith (Beaver, 1973a). As for their relatives, Cn. annectans is phloeophagous (Wood, 1967), except that larger larvae may feed in the pith. At least two Bothrosternus species are xylomycetophagous in pith and inbreed (Table 6. Three species of Eupagiocerus studied by Wood (1965) also breed in pith, and one is apparently xylomycetophagous. No examples of female-initiation are known in the tribe, but for most species it is not known which sex begins gallery construction.

\section{Phloeotribini}

In a letter to Beaver (cited in Beaver, 1973) and in his 1982 monograph, S. L. Wood has stated that Phloeotribus males begin the new attacks. However, in a letter to me (Oct. 1981) Wood withdraws this claim, stating that galleries are femaleinitiated. Beaver (1973) found recently started Phloeotribus spp. gallery systems with only a female, as have I for Ph. demessus Bland. (unpubl. data). Wilson (1909) and Gossard (1913) describe $P h$. liminaris as female-initiated. The European $P h$. scarabaeoides Bernard has the same habits (Russo, 1938). In the other phloeotribine genus, Aricerus, females begin the monogynous systems (Wood, Oct. 1981 letter). 


\section{Phloeosinini}

Wood (1982) also states that in monogynous Phloeosinus (pp. 15, 287) and Chramesus (p. 316) it is the male which constructs the entrance to the gallery system. The only species in either genus to which Wood directly attributes this behaviour is Chramesus hicoriae LeC.-a species studied by Blackman \& Stage (1924), who reported that the female was the sex initiating galleries. Females also are reported to be the first arriving sex in Ph.cupressi Hopk. (Bright \& Stark, 1973), Ph. sequoiae Hopk. (DeLeon, 1952), Ph. cristatus (LeG.) (Bright \& Stark, 1973), Ph. cedri Schedl (Chararas et al., 1968), and Ph. nanus Browne (Beaver \& Browne, 1978). The only literature records for male initiation involve polygynous European species (Chararas, 1962). Nothing is known of gallery initiation in other phloeosinine genera. Thus, there are no literature records documenting maleinitiated monogyny in Phloeosinini, and Wood's claims must be verified.

\section{Scolytini}

Males of Scolytus scolytus ( $=S$. destructor) produce an 'aggregation' pheromone (Borden \& King, 1977), though this species is apparently tachygamous (Fisher, 1931 ; Beaver, 1966a). Females produce the attractants in $S$. mali (Rudinsky et al., 1978 ) and S. multistriatus (Peacock et al., 1971), and other monogynous species also are female-initiated, where the initiating sex is known (Table 2). Camptocerus has female-initiated monogyny and is xylomycetophagous. Cnemonyx (=Loganius) is known to be monogynous (Wood, 1961), as is Scolytopsis (Wood, 1971a).

\section{Citenophorini}

Scolytodes (s. str.) is monogynous, and male-initiated. Scolytodes (Hexacolus) usually have radiate galleries and are probably harem polygynous (Wood, 1961, 1969a). The other three genera are monogynous (Wood, 1982).

\section{Scolytoplatypodini}

Browne (1963) reports Scolytoplatypus acuminatus to be male-initiated. Nakashima (1975: 9) states that in 'most' Scolytoplatypus species males initiate. However, Wood (pers. comm., Dec. 1980) found four Japanese species to be female-initiated. The genus is xylomycetophagous, and in $S$, acuminatus both parents were said to die after the brood leaves. The tribe is a geographic replacement of Ctenophorini (Wood, 1978).

Morphological evidence as well argues against the likelihood of male initiation occurring in monogynous Phloeosinini and Scolytoplatypodini. There is a very strong relationship in Scolytidae (first pointed out to me by Wood) between form of the frons and which sex initiates or follows: where the forehead is dimorphic, that of the initiating sex usually is convex while that of following sex is frequently flat or concave. The correlation is so good that indications to the contrary suggest that either a mistake has been made in sexing the beetles or in assigning the roles. In phloeosinines and Scolytoplatypus the male has a concave frons and the female a flat or convex frons (Browne, 1971; Nobuchi, 1980; Wood, 1982). 
Xyloterini

Nakashima (1975:9) says males initiate galleries in Trypodendron signatum. Wood observed this species recently (Oct. 1981 letter) and found females initiating the gallery systems as in other Trypodendron and Xyloterinus politus (see Tables 2 \& 6). Nakashima's statement is probably incorrect.

\section{Corthylini}

In the largely phloeophagous subtribe Pityophthorina, Pseudopityophthorus minutissimus (Zimm.) and Ps. pruinosus Eichhoff are known to be male-initiated monogynous species (McMullen et al., 1955; Rexrode et al., 1965; Rexrode, 1969; pers. obs. in Michigan, both species). Wood (1982), however, characterizes the genus as bigynous. While not specifying bigyny for any particular species, he represents minutissimus and pruinosus plus 11 other species as having habits "as described for the genus". The aforementioned pair of species is definitely monogynous in the northern U.S.; whether they are bigynous elsewhere remains to be ascertained. Other Pityophthorina (sensu Wood, 1978) are harem polygynous (Dendroterus Bland., Gnatholeptus Blackman, Phelloterus Wood, Styphlosoma Bland., most Pityophthorus Eichhoff, some Araptus Eichhoff) or monogynous (Conophthorus Hopk., Dacnophthorus Wood, Pityoborus Blackman, Pityotrichus Wood, some Araptus and a few Pityophthorus) (see Bright, 1981; Wood, 1982). Females are only known to initiate galleries in Conophthorus (see Table 2) and in parthenogenetic Pityophthorus puberulus (LeC.) (Deyrup \& Kirkendall, in prep.).

Corthylina are ambrosia beetles, and no taxa are known to have female-initiated gallery systems. Males have been observed to begin the galleries in Corthylus Erichson (Finnegan, 1967), Gnathotrichus Eichhoff (McLean \& Borden, 1975), Gnathotrupes Schedl (Wood, 1982), and Microcorthylus Ferrari (Wood, 1982). Monarthrum Kirsch and Corthylus columbianus Hopk. (Table 3) are known to have polygynous gallery systems; in both, galleries are begun by the male. The only other member of the subtribe said to be harem polygynous is Amphicranus fastigiatus Bland. (Wood, 1982). The vast majority of Corthylina are apparently monogynous. Males have a convex frons and females a flat or concave frons (Wood, 1982). Thus, from what we now know, it would appear that maleinitiation is the rule in the Corthylini.

\section{Harem polygyny}

Harem polygyny in bark and ambrosia beetles is characterized by two features: (1) at least some females join gallery systems in which one female is already present; (2) males initiate gallery construction and produce odours attractive to both sexes (though more so to females). Various forms of harem polygyny have probably arisen at least 11 times in Scolytidae plus one among the primitive Platypodidae: Hylesinus varius, Phloeosinus in Europe (see Table 3) and SE Asia (S.L. Wood, pers. comm.), Chramesus incomptus (Wood, 1967), Polygraphini, neotropical Scolytus, Scolytodes, Micracini, Dendrocranulus, Ipini, Scolytogenes, and Corthylini, and Protoplatypus. Harem polygyny may well have evolved more than once within some of these groups; for example, lone instances of the mating system xccur in the otherwise monogynous corthyline genera Pityoborus, Amphicranus, and Corthylus (see below). 


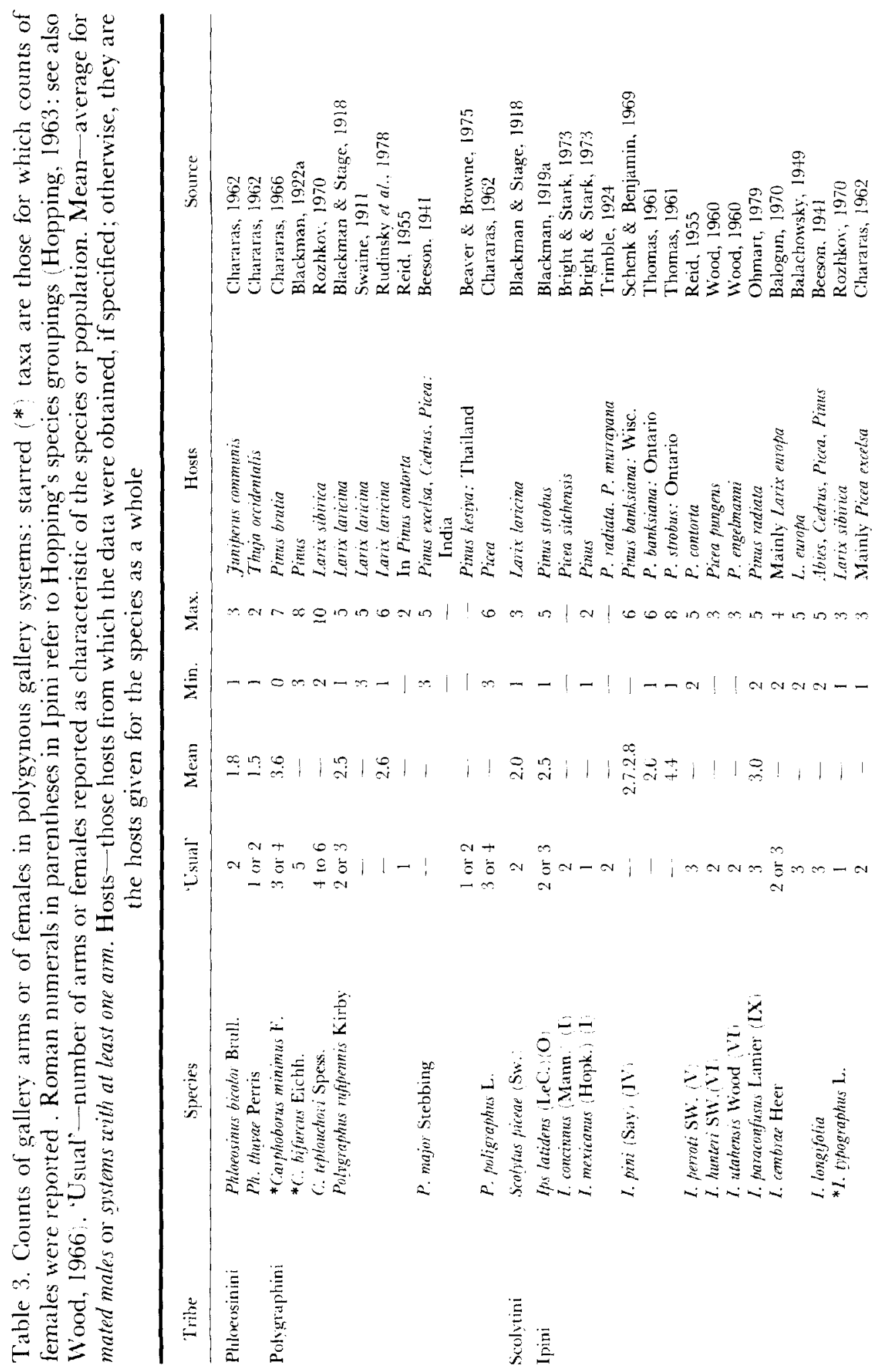



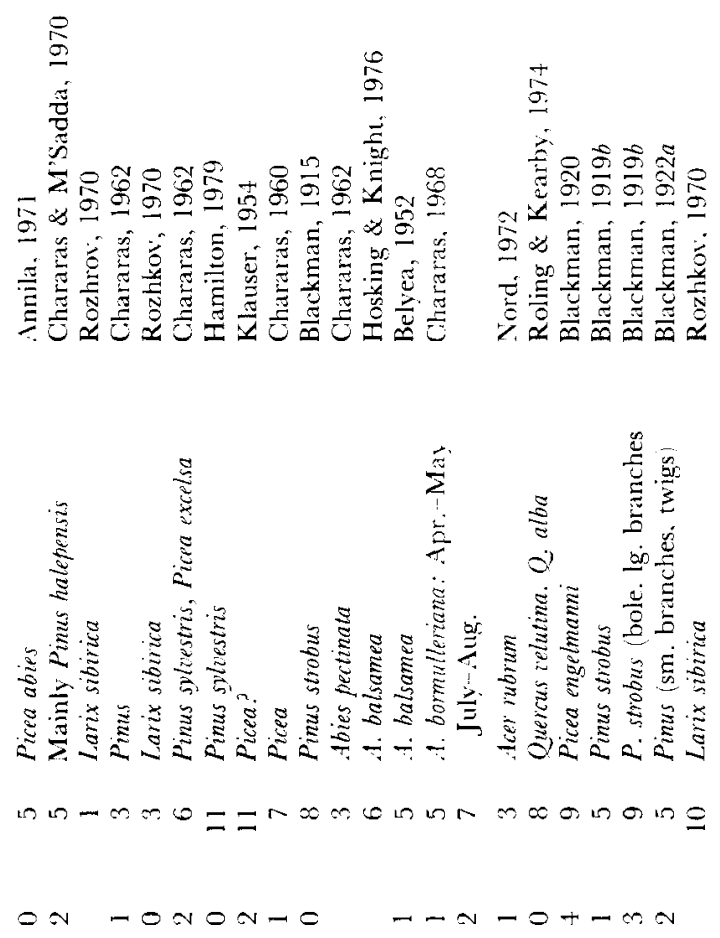

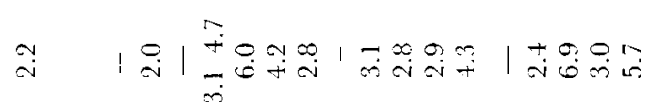

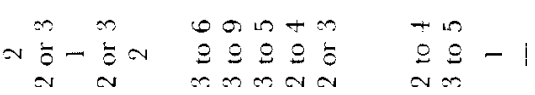

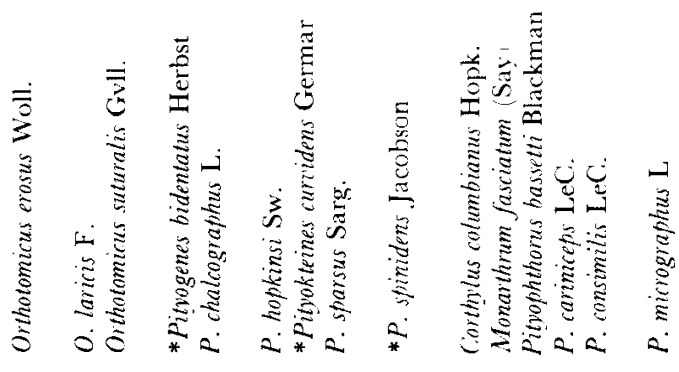

$\stackrel{\Xi}{E}$ 
In Table 3, I have presented descriptive information on those species for which researchers have specified the range or the maximum number of females or gallery arms and either the 'usual' or mean number. (In many papers a value is given as being the 'usual', 'normal', or 'regular' case.) A few reports having fewer data have been included for within-species comparisons.

Most authors have asserted that the number of gallery arms represents the number of females that were present in the gallery system, and so most such data are based on analyses of engravings. This assumption remains to be rigorously tested for most species; study of a series of radiographs of gallery systems and dissection of hundreds of galleries has shown it to not always be true for Pityophthorus lautus (pers. obs.). In a study of Ips paraconfusus, Barr (1969) discovered that six of 53 females known to have remained in their original gallery systems made two arms, and one made three.

\section{Lesser known cases}

Besides the taxa included in Table 3, general statements have been given as representative of some genera and are presented here in order to give a broader view of the distribution of harem polygyny in bark beetles.

One of the taxa Wood believes to be structurally intermediate between Platypodidae and Scolytidae, Protoplatypus vetulus Wood from New Guinea, makes radiate galleries in inner bark; the "beetles appeared to be polygynous" (Wood, 1973). In the Polygraphini, Chortastus Schauf. is said (Schedl, 1959) to have both monogynous species and species with two- to three-armed gallery systems. As with Phloeosinus bicolor (Table 4) a small number of Scolytus species (Scolytini) and (hramesus incomptus Wood (Phloeosinini) are bigynous, most males being found with two females (Wood, 1967, 1971a, 1982). I know of no organisms other than bark beetles in which males are regularly paired with exactly two females. Many of those Scolytodes Ferrari (Ctenophorini) formerly placed in Hexacolus Eichhoff are harem polygynous and phloeophagous (Wood, 1961, 1969a), while all Scolytodes (s. str.) known to Wood are "monogramous' (Wood, 1969a: 16). Stephen L. Wood and M. Deyrup have both told me they consider all Micracini (other than the monogynous Micracisella) they have collected to be bigynous; the only micracine data to the contrary with which I am familiar are that Micracis suturalis LeConte (=meridianus Blackman) usually has two or three females (Blackman, 1920), and that Lanurgus xanthophloeae Schedl is monogynous in dry twigs (Schedl, 1962: 44). Most Micracini are xylophagous in dry, sound wood of small or moderate-size branches; Pseudothysanoes Blackman breeds in inner (and outer?) bark.

Bright (1963) and Wood (1982) assert that Dryocoetes Eichh. (Dryocoetini) is harem polygynous, but I can find little support for this in the literature (see Table 2b). Although Dryocoetes species do make multiple-armed gallery systems, Browne (1961a), Schedl (1961) and Chararas (1962) all characterize this phloeophagous genus as 'monogamous', as does W. D. Hamilton (for D. villosus, pers. comm.). 'The only exception I have encountered is based on a drawing in a paper by Swaine (1911:89) which shows two females and one male in a single gallery system of $D$. autographus Ratz. - a species said by Chararas to be 'monogamous'. Wood (1982) states that some species (not specified) of another dryocoetine, Dendrocranulus, are harem polygynous.

In the otherwise monogynous tribe Cryphalini, Scolytogenes Eichh. (=Cryphalomorphus Schauf.) may provide the only examples of harem polygyny. Roberts 


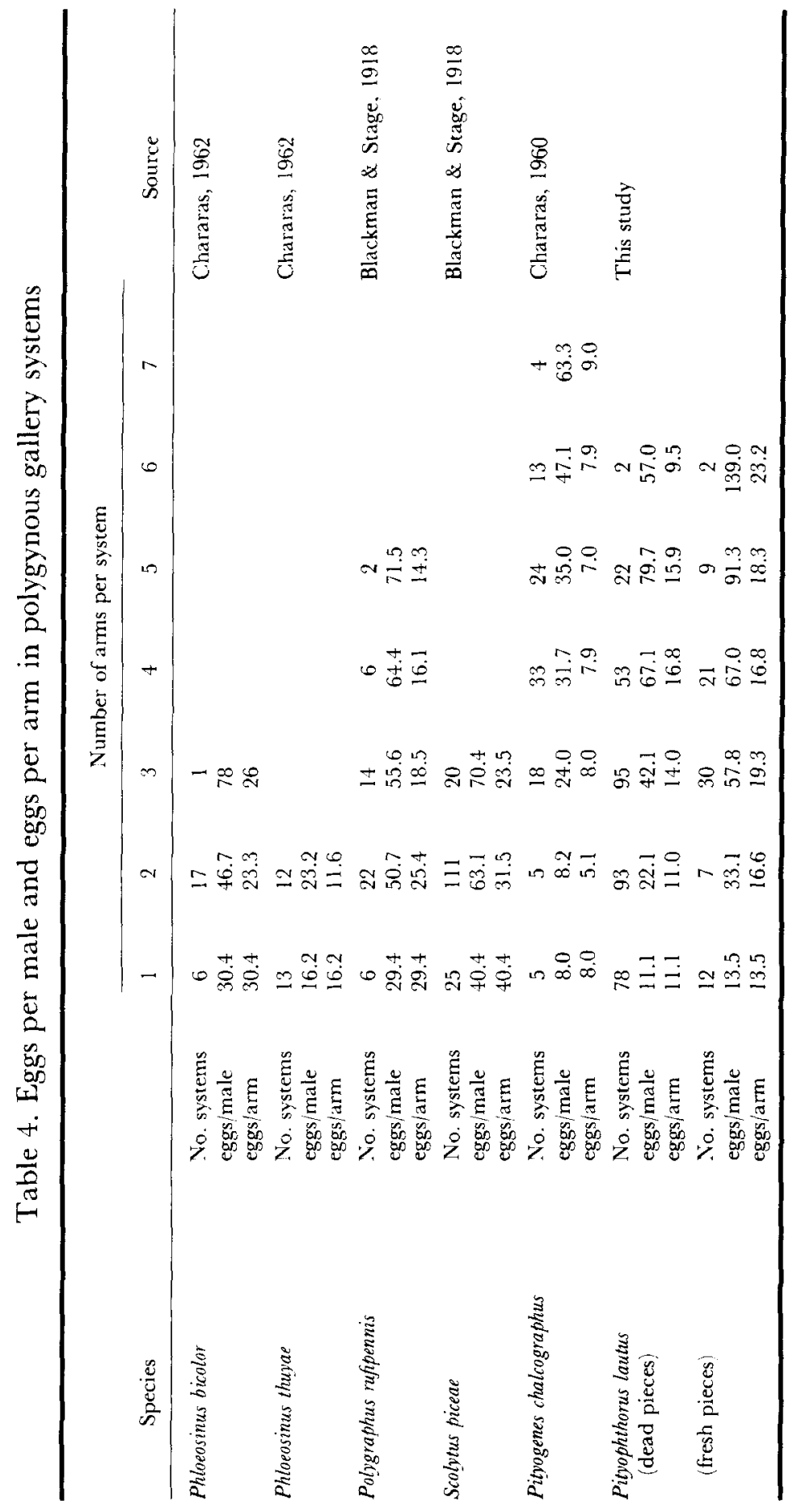


(1976) records the phloeophagous S. grossepunctatus (Browne) and S. leprosulus (Browne) from Fiji as being harem polygynous with a ratio of three females per male. Schedl (1958) comments briefly on the polygynous nature of $S$. pleiocarpae (Schedl) in central Africa.

The only ipine genus not represented in Tables 3 and 4 is Acanthotomicus Bland. (= Mimips Egg.), said to include both phloeophagous and xylophagous species (Nobuchi, 1969). Schedl (1962: 71) states that some African members of the genus appear to be monogynous while others are decidedly harem polygynous. (Ips mexicanus in California is another ipine said to be primarily monogynous: Bright \& Stark, 1973.)

Finally, a number of genera in the Corthylini-Pityophthorina are characterized as harem polygynous: Dendroterus Bland. and Gnatholeptus Blackman (Wood, 1982); Phelloterus Wood (Wood, 1971a) with one to four females per male, one to five arms per gallery system; and Styphlosoma Bland. with one to four gallery arms per system (Wood, 1971a). In addition, in Araptus Eichh. at least 10 species have radiate galleries, with $A$. laudatus Wood having two to nine females per male in each system (Wood, 1982). In the otherwise monogynous Pityoborus Blackman (see Wood, 1982), P. comatus Blackman was described as polygynous (Blackman, 1922a). Finally, in the Corthylini-Corthylina, Amphicranus fastigiatus Bland. is harem polygynous in an otherwise monogynous genus of ambrosia beetles (Wood, 1982).

\section{Describing harem polygyny}

To the degree that the number of gallery arms in a system corresponds to the number of females in it, Table 3 provides a broad overview of harem size in polygynous scolytids. At one end of the spectrum we find species which differ only slightly or only in some hosts or localities from being monogamous or brachygamous (e.g. Polygraphus major and P. rufipennis, Ips mexicanus and $I$. typographus, Orthotomicus laricis, Corthylus columbianus). Then we find species which, instead of normally having one female per male, normally have two (as mentioned previously). Moderately polygynous species, with a usual number of two or three females per system, are quite common; highly polygynous taxa are less so, most examples being from Carphoborus, Pityogenes, Pityokteines, and Pityophthorus.

Distributions of arms or females per gallery system have only occasionally been published. Hamilton (1979) presented information on the numbers of females per system for Pityogenes bidentatus. Two (destructive) samples from the same area suggest that harem sizes start out in May somewhat overdispersed ( 11 of 65 systems with more than seven females; variance much higher than the mean) but by June have 'condensed' to a more-or-less random distribution (slightly lower mean; no systems with more than seven females; mean and variance about equal). Other distributions of harem size (or arms per system) have been given by Blackman (1915) for Pityogenes hopkinsi, Klauser (1954) and Chararas (1960, republished in Chararas, 1962) for Pityogenes chalcographus, Rozhkov (1970) for Orthotomicus suturalis, Blackman (1919a) for Ips latidens (LeC.) (as longidens Sw.), Annila (1971) for Ips typographus, and Blackman \& Stage (1918) for Polygraphus rufipennis and Scolytus piceae. Nord (1972) reports that, of 52 galleries of Corthylus columbianus examined, nine gallery systems had two females and one had three, the remainder being monogynous. Chararas (1968) presents two distributions for Pityokteines 
spinidens, one from "April-May" and the other from "15 July-end of Aug." The mean number of females per male for the second data set $(4.0: 1)$ is much higher than that for the earlier collection $(2.3: 1)$.

Intraspecific variation in average harem size may result from differences in the host species utilized. Thus, Ips typographus, Orthotomicus erosus and $O$. suturalis are all less polygynous in Larix than in Picea or Pinus; the reverse is true for Polygraphus rufpennis. Such interpopulational differences could result from many factors, but the possibility of important host effects deserves research.

The forms taken by most of the distributions are such that they could have arisen from random processes (e.g. Hamilton, 1979:203), and therefore can tell us little about why some males accrue more females than others. Furthermore, in the papers cited above few details are given about the sources of the beetles-how many different plants are involved, how the resource quality varies among samples, and so forth. It is not clear, therefore, whether the distributions are drawn from a range of host material and thus estimate the distribution of harem sizes of the population, or are taken from single stems or branches and hence represent the distributions of females that have bred or are breeding in single attack sites. In the first situation, some males may obtain more females than others by being in 'better' breeding material, while in the second case resource quality may be relatively homogeneous, requiring us to look for other explanations for the observed variation in male mating success.

\section{Measuring reproductive success}

So far, we have been discussing one level at which we can estimate male reproductive success - number of matings. The obvious question arises, do males that get more gallery arms or more females get more eggs? At the same time we must ask how female reproductive success is affected by sharing a gallery system with other females. These are not topics that have attracted a great deal of study. The scant information bearing on these questions that I have found is presented in Table 4, along with my previously unpublished data for Pityophthorus lautus (methods described below).

The data for the less-polygynous species in Table 4-Phloeosinus, Polygraphus

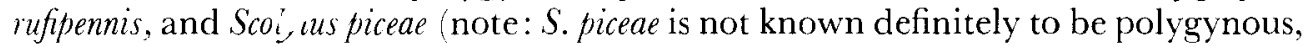
see Blackman \& Stage, 1918)-indicate that with an increase in arms comes a decrease in the average egg niches per arm. Thus, additional arms add fewer and fewer eggs per gallery system. Gallery arm number does not have this effect in more highly-polygynous species-Pityogenes chalcographus and Pityophthorus lautus. In addition, Blackman \& Stage (1918) observed that the upward-directed firststarted arm in a $S$. piceae gallery system usually was longer and had more niches than the later, downward-directed second and third arms.

Two explanations can be proffered for the occurrence of fewer eggs per arm in systems with higher numbers of arms. First, the effect could result, at least in part, from many subsequent arms being very short (the first arm being more or less as long as the only arm of a monogynous system). Distinctly shorter arms might arise from reproduction by older females (such as by the first female, after completion of the first arm), or simply by later-arriving females who find a lowered resource quality and do not stay long (see Thomson \& Sahota, 1981). Second, lower trerages could result from physiological or behavioural adjustments to effects of ncreased competition as apparently are made by monogynous Dendroctonus (e.g. 


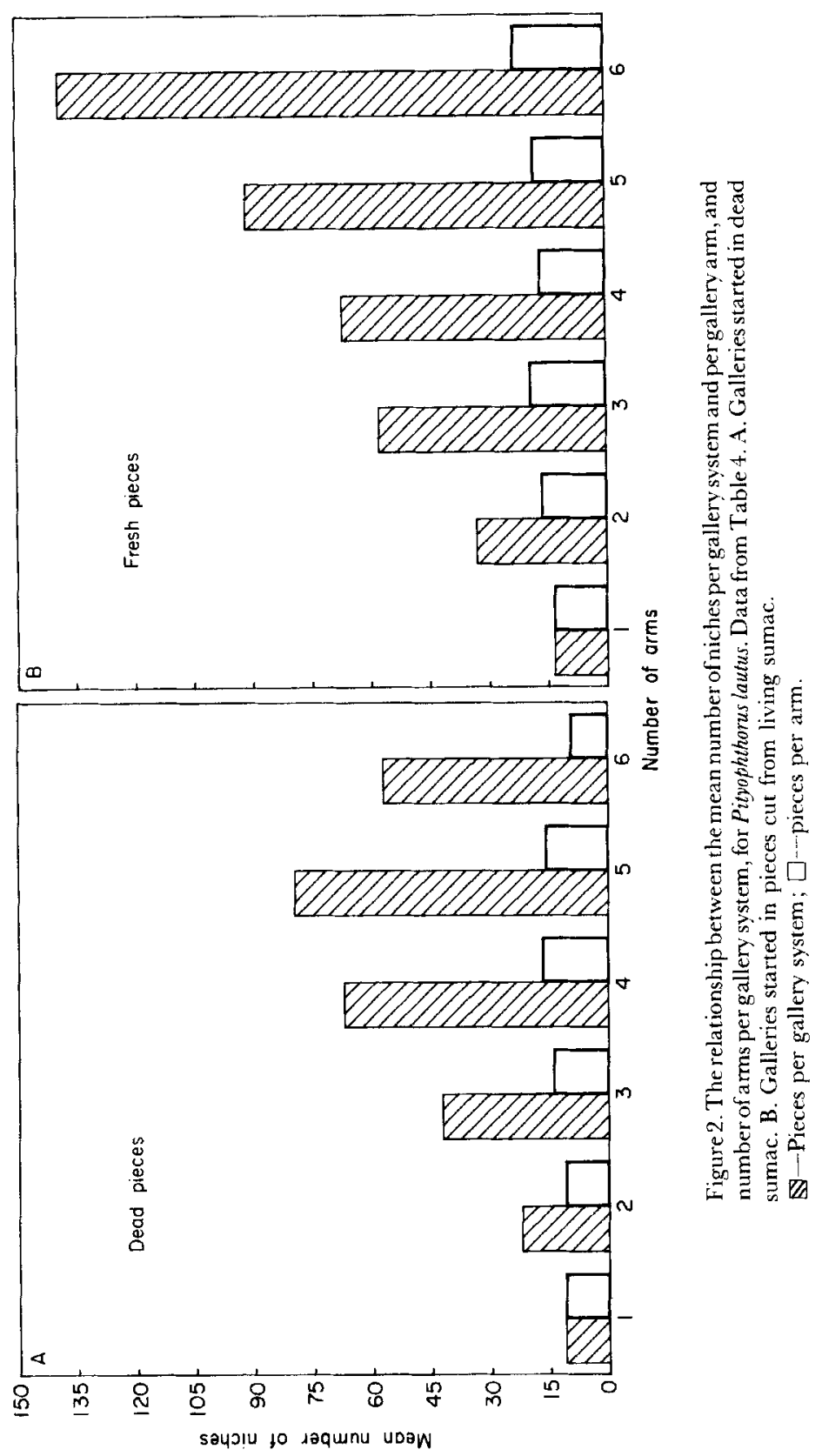




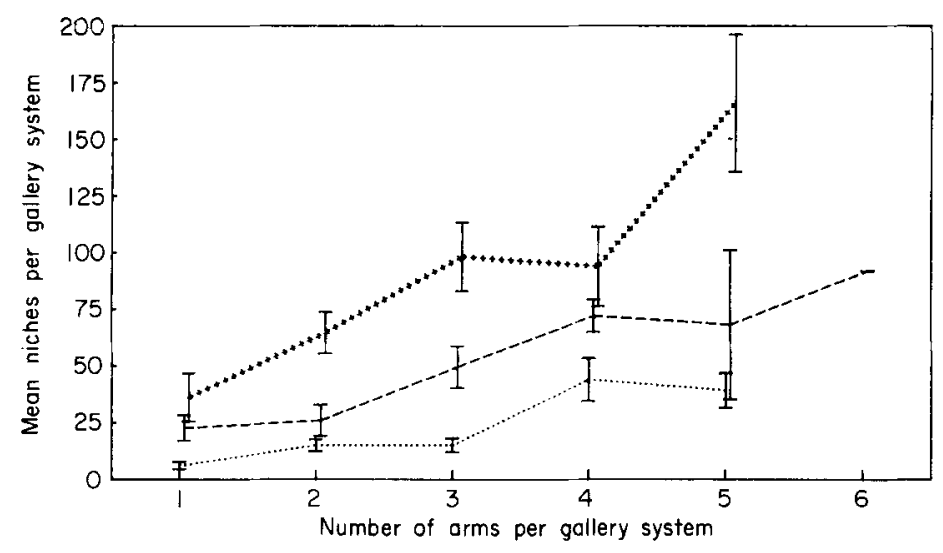

Figure 3. The relationship between male reproductive success, as measured by the number of eggs laid in his gallery system, and the number of gallery arms in that system, for Pityophthorus lautus breeding in pieces of low, medium and high quality (see text). Bars represent one standard error of the mean. ....., Low quality; --.-; medium quality; +++ , high quality.

McMullen \& Atkins, 1961 ; Cole, 1967; Coulson et al. 1976; Thomson \& Sahota, 1981).

For the more highly polygynous species, the pattern would seem to be different. The ratio of eggs per arm does not decrease with increasing numbers of arms. (Table 4; Figs 2A, B \& 3) and thus eggs per gallery system is proportional to the number of arms in the system (which presumably bears some relationship to the number of females attracted).

Figure 3 has been included to illustrate the fact that even when one removes the effects of varying (among pieces) resource quality, niches per gallery system ('eggs male $^{-1}$ ' of Table 4 ) increases more or less linearly with arm number. The pieces used for Fig. 3 were from those described below and were selected as follows, using 'niches $\mathrm{mm}^{-1}$ ' as an indicator of resource quality (explained further below). For 'low' quality, four pieces cut from one dead ramet were used, ranging from 0.73 to 1.11 niches $\mathrm{mm}^{-1}$ and from which a total of 57 gallery systems (148 arms) had been sampled; for 'medium' quality, two pieces cut from one dead ramet, 1.72 and 2.07 niches $\mathrm{mm}^{-1}, 36$ gallery systems (102 arms); for 'high' quality, seven pieces cut from two dead ramets, 2.05 to 2.70 niches $\mathrm{mm}^{-1}$ and 29 gallery systems (85 arms).

Although the average number of eggs per arm varies with resource quality, the mean number of eggs per gallery system increases with arm number in similar fashion in pieces of relatively low, medium, and relatively high quality. Though the patterns are somewhat irregular, there is no strong tendency towards a drop-off in eggs $\mathrm{arm}^{-1}$ with increasing arm size. Overall, average niches gallery system is significantly correlated with the number of niches $\mathrm{mm}^{-1}\left(r^{2}=0.43, \mathcal{N}=343\right.$ gallery systems in 'dead' pieces).

Conclusions regarding reproductive behaviour and success must be drawn with caution. At best, they can give a picture of the general nature of harem polygyny in a species - if sampling captures the variability that occurs - but inferences about the processes giving rise to the harem distributions may not be justified. For example, the increases seen in eggs $\operatorname{arm}^{-1}$ for $P$. lautus as arm number goes up (within a certain range: Table 4, Figs $2 \mathrm{~A}, \mathrm{~B} \& 3$ : 'medium' quality) do not result 
from some form of social facilitation whereby females in larger harems lay more eggs. Rather, males in better quality areas (higher in nitrogen and carbohydrates) accumulate more female reproductive effort - females stay longer and lay more eggs $\mathrm{mm}^{-1}$ of gallery arm-and consequently acquire more females and more arms as time passes (discussed more fully below, and in Kirkendall, in prep.). Also, simply counting arms masks the fact that arms can have only one or a few eggs, as is frequently the case for $P$. lautus gallery systems in crowded or poor material. In extremely crowded samples containing Pityogenes chalcographus, Chararas (1960) reported $72^{\circ}$ o of 427 gallery arms had 10 or fewer eggs; on the other hand, Klauser (1954; data given in Chararas) took $P$. chalcographus samples from a larger variety of conditions and much lower densities and found only $5^{\circ} \%$ of 451 gallery arms had so few eggs - even though average arm length for the two studies was identical $(20 \mathrm{~mm})$, and the distributions of length very similar. Females in Klauser's samples averaged over three times as many niches $\mathrm{mm}^{-1}$ as those in Chararas's pieces; whether this difference is due to differences in resource quality or in attack density cannot be ascertained from the data presented. My unpublished data for $P$. lautus do not suggest a strong effect of density on niches $\mathrm{mm}^{-1}$, though a weak one may exist. Some Dendroctonus researchers report no such effect (Thomson \& Sahota, 1981), while others do find an inverse relationship between density and niches (unit length-1) (McMullen \& Atkins, 1961). Part of the problem is that density and niches (unit length) $)^{-1}$ may both increase, at least initially, with resource quality.

\section{The nature of harem polygyny in $\mathrm{P}$. lautus}

A different view of harem size is afforded by Table 5 . These data were extracted from radiographs taken over the first 7 weeks of $P$. lautus reproductive activity in 1979. Set 1 ( 10 pieces from six ramets of Rhus glabra) was cut after the first flight from ramets with fresh attacks, all from one smooth sumac study site (' $\mathrm{A}$ ') on the $\mathrm{E}$. S. George Reserve in southern Michigan (Putnam Township, Livingston Co.). 'Three pieces were cut from stem and branches of one ramet, two from each of two ramets, and one piece each from the remaining three. Reasonably straight segments were cut $15-20 \mathrm{~cm}$ long and the ends waxed to retard dessication; the pieces were then attached by plant ties to a row of bamboo plant stakes in site ' $A$ ', three or four to a stake, and were thereafter only removed briefly from the sumac patch in order to be X-rayed (after each major flight during the first two weeks and then approximately once a week). Set 2 (three pieces from one stem) was cut from a large ramet in site ' $\mathrm{E}$ ' on $26 \mathrm{May}$, and treated the same as Set 1 (except that the pieces were placed out in ' $E$ ', tied to a colonized sumac branch). These three segments were somewhat shorter than most of the ' $A$ ' pieces, totalling only $51 \mathrm{~cm}$. The ' $E$ ' ramet had died much more recently than any of the six ramets in ' $A$ ', and the inner bark was still moist and green. Major flights occurred during the evenings of 18, 20, 31 May and 2 June; a few beetles were collected from window traps 29 May and 1 Junc. Cool, windy, or rainy evenings precluded flights on the intervening evenings. The number of females present was recorded for each harem in each piece, using those gallery systems which could be clearly seen in radiographs throughout the season.

I present these data to show the differences in harem size that can exist between samples, and the fluidity of harem systems in $P$. lautus. The two sets of pieces 
Table 5. Number of Pityophthorus lautus harems with $0-7$ females (from analyses of a sequence of radiographs). See text for details

\begin{tabular}{|c|c|c|c|c|c|c|c|c|c|c|c|c|}
\hline \multirow[b]{2}{*}{ Date } & \multicolumn{8}{|c|}{ Harem size } & \multirow[b]{2}{*}{ Females } & \multirow[b]{2}{*}{ Males } & \multirow[b]{2}{*}{ Females: Male } & \multirow{2}{*}{$\begin{array}{c}\text { Total } \\
\text { abandoned }\end{array}$} \\
\hline & 0 & 1 & 2 & 3 & 4 & 5 & 6 & 7 & & & & \\
\hline \multicolumn{13}{|c|}{ Set $1(10 \mathrm{sumac}$ from ' $A$ ') } \\
\hline $20 \mathrm{May}$ & 32 & 6 & & 1 & & & & & 9 & 39 & 0.2 & - \\
\hline $30 \mathrm{May}$ & 27 & 11 & 1 & & & & & & 13 & 39 & 0.3 & 2 \\
\hline 7 June & 15 & 18 & 3 & 1 & & & & & 27 & 37 & 0.7 & 7 \\
\hline 13 June & 7 & 15 & 3 & & & & & & 21 & 25 & 0.8 & 19 \\
\hline 23 June & 10 & 6 & 3 & & & & & & 12 & 19 & 0.6 & 25 \\
\hline 2 July & 8 & 7 & 4 & & & & & & 15 & 19 & 0.8 & 28 \\
\hline \multicolumn{13}{|c|}{ Set 2 (3 sumac pieces from ' $E$ ') } \\
\hline 27 May & 23 & 1 & & & & & & & 1 & 24 & 0.0 & 0 \\
\hline 6 June & 14 & 5 & 5 & 12 & 4 & 3 & & & 82 & 43 & 1.9 & 0 \\
\hline 13 June & 7 & 8 & 4 & 20 & 1 & 2 & & & 90 & 42 & 2.1 & 1 \\
\hline 23 June & & 6 & 13 & 19 & 5 & 4 & & $l$ & 136 & 48 & 2.8 & 1 \\
\hline l July & & 6 & 14 & 24 & 3 & 1 & & & 123 & 48 & 2.6 & 1 \\
\hline
\end{tabular}

obviously differed greatly in their acceptability to the beetles. The pieces from ' $A$ ' never attained a collective 1:1 ratio of females per male, while the number of females per male in Set 2 steadily climbed over the first 6 weeks, peaking at nearly three females per system. No harems with more than three females were seen in Set 1 ; three females per harem soon became the mode for Set 2 . Only one gallery system in the second set had been abandoned by its founder after 7 weeks, while over two-thirds of the Set 1 systems recorded for Week 7 had been abandoned. Some Set 1 males never got females; only one Set 2 male remained unmated during the period of observation. Clearly, one would get a very different picture of the nature of harem polygyny in $P$. lautus had one by chance studied only Set 1 or only Set 2 .

The amount of movement by females, and to a lesser extent by males, seen in radiographs of the same gallery system taken one or a few days apart was an unexpected and striking phenomenon. Female movement among harems can also be inferred from careful examination of Table 5 (for example, compare 6 June with 13 June: there are noticeable shifts in harem size frequency but little change in the total number of females seen . Some changes are undoubtedly due either to females moving to new gallery systems in the same piece (as occurred in laboratory pieces used for other experiments, where immigration was impossible) or to emigration and immigration. The largest harems within a piece frequently lose a female during the week (or less) after reaching their peak size, as is suggested in Table 5 by the changes between 23 June and 1 July for Set 2 (see also Hamilton's May vs. June Pityogenes bidentatus collections mentioned previously, though the difference in harem size distribution between months could be due to underlying differences in resource quality among the pieces dissected in each month). Note too that the large increase in females between 13 and 23 June in Set 2 came not during major flights-relatively few beetles are found in window traps after any one night this late in the season-but must be due to a steady flux of females. Thus, there are significant differences among females in how long they stay in a given harem, arising both from some aspect of the breeding material they are in, and from within-harem crowding. 
The temporal pattern of changes in sex ratio and numbers of females and males present in gallery systems followed in 1980 sites are roughly similar to the pattern discussed above (Fig. 4). The procedures for obtaining these data and the data in Figs 2A, B and 3 did not differ substantially from those used for gathering the 1979 data. The main differences were that $25 \mathrm{~cm}$ pieces were cut from either (a) already dead but not yet attacked smooth sumac ramets (='dead' pieces) or (b) living ramets (='fresh' pieces), in three different E. S. George Reserve sumac patch study sites, the bottommost $5 \mathrm{~cm}$ removed and frozen for later resource quality analyses, and eight pairs then tied in end to end contact to plant stakes set $2 \mathrm{~m}$ apart in an open centre square with three stakes to a side. Sets of eight stakes were placed out in the midst of sumac patches ' $A$ ' and ' $C$ ' prior to the first major flight of $P$. lautus, and in ' $E$ ' 1 week after flights began. In ' $A$ ' and ' $E$ ' each pair consisted of one 'dead' piece and one 'fresh' piece; all pieces used in ' $C$ ' were 'dead'. Before being placed out in the field, each 'dead' piece (i.e. eight pieces in ' $A$ ' and ' $E$ ', all 16 of ' $\mathrm{C}$ ') was started with two males who were allowed at least $48 \mathrm{~h}$ to establish themselves under the bark. Sixteen pairs of 'dead' pieces were placed out in another site (' $\mathrm{F}$ ') in a $4 \times 4$ arrangement of stakes $2 \mathrm{~m}$ apart; one piece from every other stake was started with two males, giving eight stakes with two 'pioneer' males each and eight stakes with no initial pheromone sources.

The first flight occurred 1 day after the pieces were set out, and males had by then had sufficient time to chew out the nuptial chamber and begin producing pheromone-most had been under the bark 4-5 days. The initial presence of resident pheromone-producing males ensured rapid discovery and colonization of the experimental pieces. As with the sets in Table 5 these pieces were only removed from the field during the brief radiography sessions, at which time they were also checked for new gallery starts.

Most unused dead sumac in nature consists of dead branches or ramets in which no beetles bred during the previous season. A few new galleries are begun by overwintering males in the spring, prior to the first flight, in the newly available region of the branch or stem. Some potential breeding material is found by dispersing progeny in the fall, who may also begin gallery systems several weeks before flight the following spring. In both cases, the result is sections of dead inner bark with scattered pioneer males (plus a few females that have wandered into the dead region), not unlike my experimental set-up.

The sequence presented in Fig, 4 begins after the first two major flights of 1980 on 21 and 22 May (which were dominated by males). In ' $\mathrm{C}$ ' (the plot with four males per pair of sticks), the number of females peaks by the end of the first week; in ' $A$ ' (two males stake ${ }^{-1}$ ) by the end of the second week; while in ' $F$ ' (two males stake $^{-1}$ or zero males stake ${ }^{-1}$ ) female colonization is more drawn out, peaking by the end of Week 3. At all three sites, the number of males does not increase after the end of the first week. The decline in males and females begins first and is most rapid in the pieces colonized the earliest. Note that (a) after the first week the number of females always exceeds the number of males, and (b) since males and females leave in approximately equal numbers beginning with the second or third week, the female: male ratio in these pieces is highest near the end of oviposition. The consequences for 'instantaneous' samples of gallery system sex ratios can be severe.

While it is difficult to say how closely my experimental sticks represent the distribution of resource quality and quantity in the natural environment, nitrogen, 


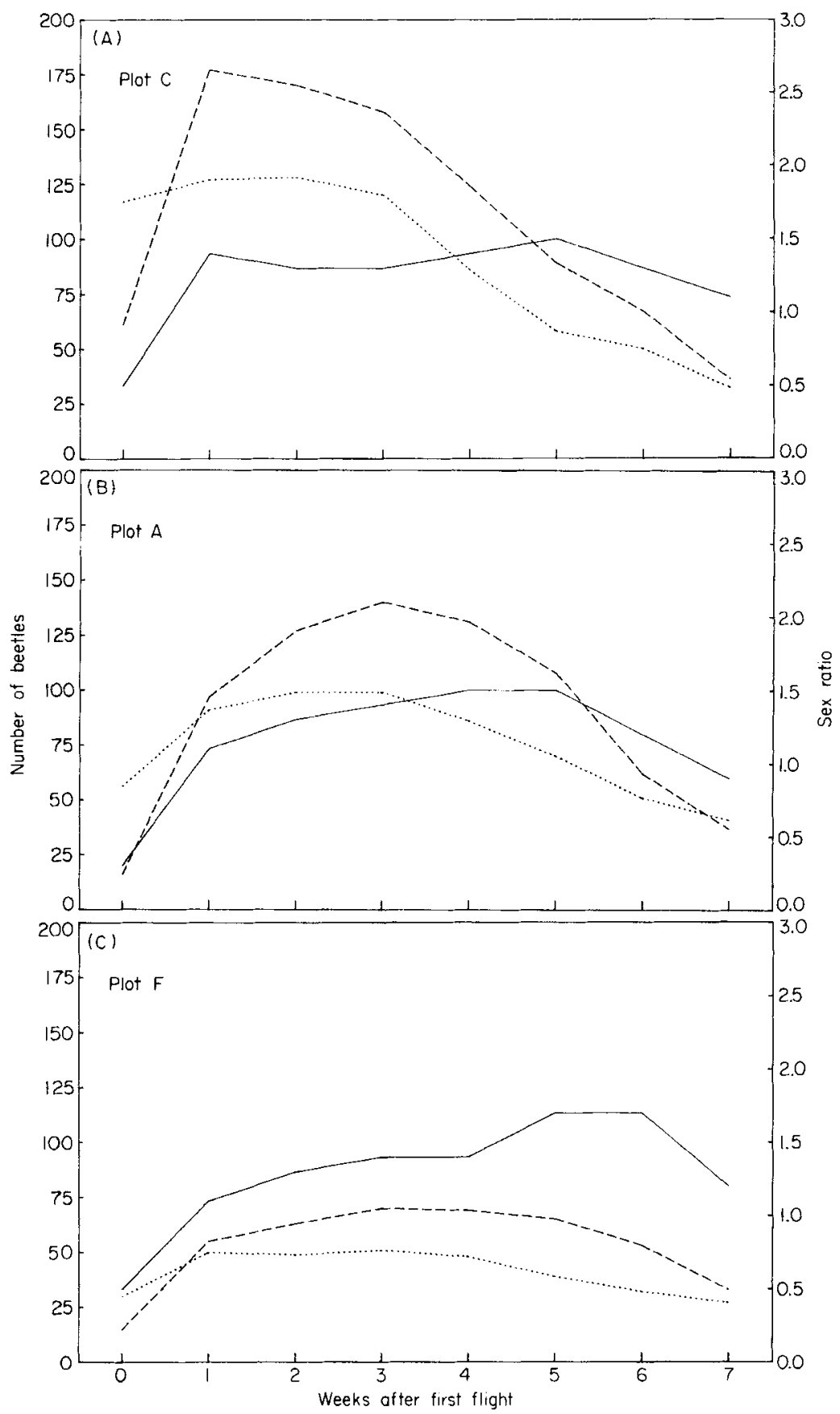

Figure 4. $\Lambda$. Temporal shifts in numbers of males and females in gallery systems of Pityophthorus lautus, in plot C. Each of the eight pairs of dead pieces was seeded with four males. B. Temporal shifts in numbers of males and females in gallery systems of Pityophthorus lautus, in plot A. Fach of the eight pairs had one dead and one fresh piece; each dead piece was seeded with two males. C. Temporal shifts in numbers of males and females in gallery systems of Pityophthorus lautus, in plot F. Every other one of the 16 pairs of dead pieces was seeded with two males. ...-., Females; ...., males; --, sex ratio. 
carbohydrates, inner bark thickness, and inner bark moisture content (my four measures of resource quality) vary considerably (Table 5 and Kirkendall, in prep.), as is reflected by the variation in the average number of niches $\mathrm{cm}^{-2}$. Since (1) each piece was cut from material that was available for breeding and quite probably would have been colonized without my minor intervention, and (2) the ramets cut were the result of a thorough, systematic search for stems or branches with a relatively straight segment (easily X-rayed) at least $25 \mathrm{~cm}$ long, it is safe to assume that my material at the least represented the range of resource qualities available to those beetles that summer, if not approximating the distribution.

From Fig. 2 we can surmise certain things about male and female behaviour at a population level, but again it must be emphasized that such data are a summation of what is happening in a number of different gallery systems in pieces of varying resource quality: females move from system to system and from piece to piece and males abandon systems after females have left (which can be as early as 1 week after beginning the gallery) or, for some males, after no females arrived.

\section{Inbreeding polygyny}

All the cases in which inbreeding polygyny is known or suspected to occur are listed in Table 6. Brother-sister and mother-son matings are known to be the rule for Coccotrypes dactyliperda F. and Xylosandrus germanus Bland., brother-sister

Table 6. Known and probable cases of inbreeding polygyny

\begin{tabular}{|c|c|c|c|}
\hline Tribe & Taxon & Larval feeding & Source \\
\hline Hyorrhynchini & Sueus Murrayama & Xylomycetophagous & Nobuchi, 1969, 197I \\
\hline 'Iomicini & Dendroctonus micans (Kugelann) & Phloeophagous & $\begin{array}{l}\text { Chararas, } 1962 \text {; Hopkins. 1909; } \\
\text { Wood, } 1963\end{array}$ \\
\hline \multirow[t]{2}{*}{ Bothrosternini } & Bothrosternus forealus (Blackman) & $\begin{array}{l}\text { Xylomycetophagous } \\
\text { (in pith) }\end{array}$ & Wood, 1968, 1982 \\
\hline & B. definitus Wood & $\begin{array}{l}\text { Xylomycetophagous } \\
\text { (in vines) }\end{array}$ & Wood, 1968, 1982 \\
\hline \multirow[t]{2}{*}{ Dryocoetini } & Coccotrypes (Eichhoff) & $\begin{array}{l}\text { Spermatophagous, occasionally } \\
\text { phloeophagous or feeding in } \\
\text { leafstalks }\end{array}$ & $\begin{array}{l}\text { Beaver, 1979a; Browne, 1961a; } \\
\text { Browne, 1963a; Herfs, 1959; } \\
\text { Janzen, 1972; Kalshoven, 1958; } \\
\text { Schedl, 1961 }\end{array}$ \\
\hline & Eulepropts Schedl & Myelophagous & Wood, 1980 \\
\hline Xyloterini & Xyloterinus politus (Say) & Xylomycetophagous & McLean \& Giese, 1967; Wood, 1957 \\
\hline Xyleborini & Entire tribe & Xylomycetophagous & $\begin{array}{l}\text { Bright, 1968; Browne, 1961a; } \\
\text { Browne, 1963a; Schedl, } 1962\end{array}$ \\
\hline \multirow[t]{7}{*}{ Cryphalini } & Ciryptucarenus (Eggers! & Myelophagous & Wood, 1954a \\
\hline & Hypothenemus (Westwood) & $\begin{array}{l}\text { Most myelophagous, some } \\
\text { spp. phlocophagous }\end{array}$ & $\begin{array}{l}\text { Blackman, 1922a; Browne, 1961a; } \\
\text { Wood, 1954a }\end{array}$ \\
\hline & Macrocryphalus (Nobuchi) & $?$ & Nobuchi, 1981a \\
\hline & Margadillius loranthus (Schedl) & Spermatophagous & Kalshoven, 1958 \\
\hline & Periocryphalus (Wood) & Myelophagous & Beaver, 1974a; Wood, 197la \\
\hline & Ptilopodius (Hopkins! & Phloeophagous & Browne, 196la \\
\hline & Trischidias (Hopkins) & Phloeophagous & Chamberlin, 1939; Deyrup, 1981 \\
\hline \multirow[t]{2}{*}{ Corthylini } & Araftus laevigatus (Eggers) & Spcrmatophagous & Wood, 1982 \\
\hline & A. costaricensis (Schedl) & Spermatophagous & Wood, 1982 \\
\hline
\end{tabular}


matings normal for Dendroctonus micans. For most of the taxa in the table inbreeding is inferred because (a) mating is not observed outside the parental nest, (b) males are much smaller than females, flightless, and short-lived, and (c) males are uncommon to rare - a biofacies commonly associated with inbreeding in a wide variety of invertebrates (Hamilton, 1967). Some of the included species have only one or two of these characteristics. Sueus (=Neohyorrhynchus Schedl) males are 'conspicuously' smaller than females (Nobuchi, 1971). Margadillius loranthus males seem to be rare (my interpretation of data in Kalshoven, 1958); this genus is not closely related to the other inbreeding Cryphalini. The two Araptus species have dwarfed, flightless males (Wood, 1982).

\section{Sex ratio control}

Exactly how scolytids control sex ratios is not well understood, but the degree of control they can exercise is impressive. Each of the four broods of the pith-feeding Hypothenemus dissimilis (Zimm.) that I have found in white oak or hickory twigs had exactly one male and five to seven females; Hypothenemus hampei is known to be not haplodiploid (Bergamin \& Kerr, 1951), and both Browne (1961a) and Entwistle (1964) report that eggs from unmated females do not hatch. Beaver (1976b) found no more than one male per system in the xyleborine Dryocoetoides cristatus (Fabr.) (average of 21 adults per nest), and that even the largest broods of Xyleborus splendidus Schauf. had only one male; in $X$. affinis, where the overall sex ratio is $8.5: 1,123$ of 145 culture tubes had a single son, nine had two male progeny, and three broods were all male (Roeper et al., 1980). Xyleborus ferrugineus is said to be haplodiploid (Norris \& Chu, 1970; Beeman \& Norris, 1977: 177), and in two species of the closely related genus Xylosandrus haplodiploidy has been welldocumented (Entwistle, 1964; Takagi \& Kaneko, 1966; Takenouchi \& Takagi, 1967). Browne (1961a) described broods of spermatophagous Coccotrypes zariabilis (Beeson) and C. nitidipennis Schedl. with zero (one instance), one (four), or two (one) of the 1025 pupae and adults present being male; Herfs (1959) produced experimental evidence for $C$. dactyliperda that (a) a small number of females go uninseminated by their brothers, (b) that these females initiate normal galleries in which they deposit a small number of eggs (two to seven) all of which develop to be male, (c) each female then mates with a son and (d) then kills and eats any sons that hav'e not wandered away-a somewhat less elegant but effective way of minimizing investment in males-and finally (e) the now-inseminated mothers dig out egg chambers adjoining their first ones and deposit the usual $2-5 \%$ male brood of $90 \% 100$ or more offspring. (Mother-son mating may also occur in unmated females of Xylosandrus compactus (Eichh.) (Entwistle, 1964 : bottom of p. 185), and is not uncommon in other organisms with male haploidy (see Hamilton, 1967: note 38).) I know of no cytological studies of this genus, but it will probably prove to be another derivation of haplodiploidy.

In many taxa in which individuals are known or suspected to inbreed, the sex ratio is less extreme (for example, about one of five Dendroctonus micans produced are male: Chararas, 1962) and more variable. The hypothesis that the ratio of females to males should vary directly with the probability of inbreeding among a mother's progeny (Hamilton, 1967) could readily be tested in a wide variety of locales and ecological situations, both within and among species.

For example, Hypothenemus eruditus Westwood-so-named for its type locality, "burrowing in the cover of a book of unknown antecedents" (Blandford, 
1904: 229)-is widespread throughout tropical and subtropical climes, and may be the most frequently encountered scolytid species in the world (Wood, 1977). Its diverse breeding habits, exceptional breadth of diet, and unusual ability to tolerate a wide range of moisture conditions make it a relatively easy species to locate in good numbers and hence provide researchers with considerable intraspecific variation in breeding situations. If females can control their sex ratio - as seems likely- one would predict that broods produced in small, discrete resources (e.g. twigs) would average fewer males per female than those reared in inner bark, where opportunities for intermingling with other lineages would more frequently provide the small, flightless males with non-sibling matings. Whenever a significant proportion of matings are among brother and sisters, selection favours reducing competition among sons for mates by biasing the offspring sex ratio in favour of females (Hamilton, 1967).

\section{Inbreeding in Dendroctonus micans}

The Eurasian Dendroctonus micans deserves special mention here, as it appears to be the most recently evolved instance of inbreeding polygyny. No unusual sexual dimorphism in size or form is apparent from the literature descriptions (e.g. Wood, 1963), and at least occasionally one can find a male accompanying a reproducing female-though normally mating takes place among siblings in the natal gallery (Chararas, 1962). Sex ratios are moderately female-biased (Chararas, 1962, cites Francke-Grossman to the effect that fall gallery systems have about five females per male; Chararas gives brood size as varying from 15 to 150 eggs per female). With the exception of one Chinese species Dendroctonus is an American genus, ranging throughout coniferous forests from the northern limits of tree growth in Alaska and Canada down into Guatemala; $D$. micans inhabits spruce forests from northern France into Siberia (Wood, 1963). Dendroctonus punctatus LeC.- "perhaps doubtfully distinct from the European micans" (Wood, 1963: 86)--inhabits northern spruce forests from Alaska to New York and South to West Virginia; virtually nothing is known of its pairing habits. Dendroctonus micans thus appears to fit the pattern of loss (or diminution) of sexual recombination in populations of introduced organisms or at the edge of the species' range (Glesener \& Tilman, 1978). Though $D$. micans still mates, the regular inbreeding likely has the same general genetic effect as loss of sex altogether. Comparative study of micans and punctatus could lead to valuable insights into the evolution of inbreeding.

\section{EVOLUTION OF BARK AND AMBROSIA BEETLE MATING SYSTEMS}

Since one cannot adequately discuss the evolution of phenomena not yet thoroughly described, this section is intended to acquaint bark beetle researchers with relevant current precepts of behavioural ecology and to familiarize evolutionary theorists with the life-history parameters which seem to me most important for gaining an understanding of the evolutionary processes in this group.

\section{The evolution of male residence}

'To stay or not to stay' is a question which over the millenia has confronted males of most animals that are motile in the adult stage. The crux of the problem is this: for organisms in which males invest little parentally, male reproductive success is measured in how many reproducing offspring they produce-i.e. by 
quantity rather than quality of offspring--and hence it would seem that male reproductive success would usually be maximized by inseminating as many females as possible. However, when females will copulate more than once and eggs may be fertilized by sperm from other than the first male, copulation is no assurance of reproductive success. Selection may then favour two strategies: (1) any genetically-programmed behaviour that causes males to behave in such a way as to prevent or delay a 'take-over' of a reproducing female with which they have copulated ('guarding'), and (2) behaviours that increase male success at performing such take-overs ('usurping') (Parker, 1970; see also Parker, 1974). Guarding males may lose opportunities to copulate with additional females; males that do not guard-'roamers'- - may lose the future oviposition of females with which they have mated to other roaming males. Male strategies resulting in the greatest net gain - in terms of descendants in future generations - will be favoured by selection.

Guarding of females, either before or after copulation, can take a variety of forms in insects. For example, one finds guarding of ovipositing females by territorial males, in odonates (e.g. Campanella \& Wolf, 1973; Waage, 1973) and flies (Parker, 1970 and refs.; Borgia, 1979; Mangan, 1979). Extraordinarily long couplings in stick insects (Phasmatodea) are probably another example of guarding (Sivinski, 1978, 1980). In many Lepidoptera, males thwart subsequent suitors by leaving a solid plug in the entrance to the female reproductive tract (Ehrlich \& Ehrlich, 1978). These are just a few examples of known guarding behaviours in insects and doubtless many await discovery.

Probably only two forms of guarding apply to Scolytidae and Platypodidae: long copulations, in species where couplings can be disrupted by rival males, and guarding of digging or reproducing females (usually by simply blocking the entryway). The discussion here emphasizes the latter behaviour, as the starting point for the evolution of complex mating systems in these beetles. Both types of guarding may occur together: often species in which some surface copulations take place also have plugging of entryways by males.

The following components seem to me essential to any model attempting to explain the patterns of mate-guarding by male bark and ambrosia beetles: the ratios of reproducing females to sexually-active males, both at local sites (branches, boles, and the like) and population-wide; the presence or absence of re-emergence; the degree to which breeding is synchronized; the nature of ejaculate competition; and the nature and distribution in space and time of breeding resources (see also Borgia, 1979).

Emlen (1976) and Emlen \& Oring (1977) emphasize the importance of measuring the operational sex ratio (OSR) - "the average ratio of fertilizable females to sexually active males at any given time" (Emlen \& Oring, 1977)--for understanding the intensity of sexual selection. Male behaviour in scolytids and platypodids will be affected, initially, by the population OSR, and subsequently (a) the OSR of the local breeding region and (b) the OSR at alternative attack sites to which the male could fly. Male-biased initial OSR could arise from mortality to the initiating females being higher than that to mate-seeking males; this would favour guarding, since any male with one mating would be doing better than the average mate-seeking male, and since his current female is more likely to be found than he is likely to find another female. Conversely, a female-biased OSR would favour roaming, since if all females get mated the average number of 
matings per sexually active male will be greater than one. However, it seems likely that the OSR of a given region of breeding material changes with time, and sooner or later may not be similar to the OSR of newly-attacked hosts. Males in monogynous species are thought by some to be at higher risk after females have gotten under the bark, facing as they do the hazards of being exposed to predation while flying and while walking on the surface, as well as being vulnerable when blocking a gallery entrance (e.g. Thomas, 1961). Where this is true, the population OSR will become increasingly female-biased as the season progresses, increasing the benefits to males who cease guarding and seek new females.

The OSR is also affected by the degree of polyandry exhibited (the average number of times females mate). When females (but not males) normally mate only once during a breeding season, the OSR can readily become strongly male-biased. Male bias will increase over time if females do not breed simultaneously. However, although bark beetle females may cease pheromone production upon mating, observations on a wide variety of species (cited above) suggest scolytid females are polyandrous (see also below).

$A$ factor largely independent of the OSR is the encounter rate (ER), the average number of potential mates a male will encounter in a given amount of searching. The ER for a given species will vary with the density of locatable females and with the strategies adopted by other males-ER will be high in a population with numerous nearby pheromone-producing females and few guarding males, low in a situation with scattered pheromone-dispensing females and many guarding males. The probability of takeover of a roamer's last mate will not necessarily reflect closely his ER; takeover probability will depend on factors such as the locatability of the female he is leaving and the local density of roaming males. The cost of a potential takeover will decrease, the longer his mate goes undiscovered (the closer she comes to finishing oviposition).

The synchrony of breeding affects the costs and benefits to male guarding by influencing the OSR. At one extreme, imagine a population in which all females commence breeding within a period of just a few days and there is little or no female re-emergence. Since females cease to be attractive after being mated (whether by cessation of pheromone production or because of a male-produced 'anti-aggregative' pheromone: Nijholt, 1970, 1973; Borden, 1974a), after a short period females become virtually 'invisible' to searching males. With the option of flying to new females gone, guarding will be favoured under certain circumstances (depending on the local OSR and the possible benefits from increasing the reproduction of a female by helping her).

Assume females leave the first gallery system after ovipositing for some average length of time and begin galleries anew. If the new boring activity produces attractants or if females begin to release pheromone again, the proportion of fertilizable females in the population will increase. As oviposition proceeds in a given gallery, the number of eggs remaining to be laid decreases, and hence the benefits to staying decrease (assuming male presence has evolved in the context of preventing take-overs by rival males). The combination of a decreasing expected egg-gain and an increasing number of available re-attacking females would likely favour male abandonment after a certain point in the oviposition cycle of the female he is guarding. Thus, if guarding only benefits males as a means of enforcing paternity, regular female re-emergence alone could select for brachygamy over monogamy. 
Ejaculate competition (Boorman \& Parker, 1976) will influence the costs and benefits to guarding. When the most recent male displaces most of the sperm from previous matings, the payoff to being the last male is great while the gain from being an earlier mate is little; the net effect is in the direction of guarding. As the amount of displacement decreases, the value of being the last male will decrease. (Note that non-synchronized emergence of virgin females will also have the effect of providing a continuous input of newly-available females.)

The nature and spatiotemporal distribution of resources is another significant factor influencing bark and ambrosia beetle mating systems. Most scolytoid breeding situations can be classified as 'bonanza' resources (Wilson, 1971: 135) in that they are rich food sources but are scattered and ephemeral. The fact that such habitats as, for example, dead inner bark occur in large patches that can be used simultaneously by many individuals (a broken branch, a windthrown tree, etc.) has led to the evolution of female response to female-produced mate attractants, since the incoming females can probably find a spot to start gallery construction in the same material. This leads to aggregations of females in such material. Since for at least a short time newly-arrived females will be releasing pheromones during flight periods, there will be a constant influx of males to the aggregation. When circumstances lead reproducing, female insects to be clumped, the chances of encounters between the sexes are greatly increased and sexual conflicts aggravated. Most cone-feeding, pith-feeding, and spermatophagous species would not be expected to aggregate. The spatial distribution of resources affects the costs of male searching; clumped host material should be easier to locate (a higher concentration of pheromone emanating from an area) and contain more closely spaced groups of females than evenly distributed host material. Temporal distribution affects the likelihood and success of female re-emergence and re-attack. Also, if breeding material is available primarily at the beginning of the beetles' reproductive season, competition among females for good host material will lead to high synchrony of breeding.

\section{Costs of not guarding}

Besides the possibility of a take-over, not guarding can cost a male loss of eggsor even of the female-to predators or parasites that would not have been able to gain entry had the male been plugging the entrance. Also, a female might reproduce more quickly with the male helping to remove frass-a behaviour almost universally present in males, with exceptions in some cactus-feeding Cactopinini (Wood, 1969b) and in Scolytogenes (= Cryphalomorphus) pleiocarpae (Sch.) (Schedl, 1958).

These ideas have not been carefully tested, though there are a few reports that male presence increases reproductive success of the pair. Egg parasitoids are important enemies of some phloeophagous Scolytidae (Beaver, 1966b; Ball \& Dahlsten, 1973; Berisford, 1974; Goyer \& Finger, 1980; Kudon \& Berisford, 1980); they gain access through the entrance hole, but the possibility that entrance-blocking lowers egg mortality due to such agents has not been studied. In Scholytus ventralis, Ashraf \& Berryman (1969: table 1) found galleries with pairs present had twice as many eggs as galleries with only a female present, though arm length was identical for the two categories. In species of another scolytine genus, the xylomycetophagous Camptocerus, presence of a male apparently leads to more eggs being laid and fewer deaths of immatures (Beaver, 1972: table 3). While the 
lower success of female-only gallery systems in Scolytus and Camptocerus may be due to the lack of the male, another explanation is that males discriminate among females and do not guard females of low quality. Browne (1963a) and Cachan (1957) both state that in monogamous Doliopygus (Platypodidae) males save eggs from being ejected from the nest along with frass (eggs are not laid in niches in platypodids). In laboratory experiments I found that various instars of clerid larvae (Enoclerus sp.) could not enter polygynous $P$. lautus gallery systems if a male was blocking the entrance, though they entered readily when a male was missing. Whether, and for how long, entry from the outer surface via gallery system entryways is an important threat in nature remains to be established; clerid eggs are laid on the surface and the first instars must somehow find their way under the bark, but at least later in the season clerid larvae can be found moving relatively unhindered through the well-mined inner bark. (Clerid and trogositid beetle larvae are probably important predators of most bark beetles.)

\section{Why do bark beetles re-emerge?}

Re-emergence is usually associated with construction of additional galleries. In some species, however, I suggest that it is possible that females re-emerge not to start new gallery systems but to avoid dying in the current gallery system, if corpses fuel build-up of endoparasites or predacious mites or insects which could potentially harm their offspring. My own limited observations and my reading of the literature suggest that while one frequently finds one or two dead parents in monogynous systems, dead individuals seem not to occur in many harem polygynous species. Larval mines in monogynous species usually radiate away in a very orderly fashion and doubling back is rare; hence, after hatching and a short period of feeding larvae may be out of the reach of harmful organisms fattened on their parents. In harem polygynous species, it is common to see a spaghetti-like tangle of larval feeding trails; one not infrequently finds a few larvae feeding very close to a gallery arm, crossing a gallery arm, or even moving inside a gallery arm, where they would be vulnerable to cysts, spores, mites, nematodes, or predacious larvae which had previously been partly or wholly sustained by feeding on the mother or father beetles. Illustrations of the patterns of larval mines leading away from various sorts of gallery systems can be found in most of the more general works, but especially informative are those of Kabe $(1954,1955)$ and Schedl (1959-1962).

Most often, re-emergence is for the purpose of seeking out new breeding material for further reproduction, perhaps with an intervening period of regenerative feeding. This must be a risky business, so why do females not carry out all their oviposition in one gallery system? I propose the following three hypotheses.

(1) The 'bankruptcy' hypothesis. Ovipositing females in some hosts may operate 'in the red', building up a nutrient deficit as they rapidly produce nutrient-rich eggs. Reemergence may permit 're-fuelling'. In many situations regeneration may be achieved through feeding in fresher material (in which, however, breeding is not possible). For instance, many trunk-breeding species feed in live twigs.

(2) The 'greener pastures' hypothesis. New breeding material is constantly being generated in the environment, and inhabited material deteriorates rapidly; after a certain expenditure of reproductive effort in one gallery system, the risks of leaving are outweighed by the benefits of placing remaining eggs in richer material. 
(3) The 'overcrowding' hypothesis. The density of feeding larvae may eventually reach the point that the survival of all larvae is jeopardized by the addition of more offspring: the abundant larvae already present would have already consumed much of the resource and besides would likely feed right through small larvae in their way. Female departure and new gallery construction for remaining eggs may thus be favoured.

These three hypotheses are not mutually exclusive, but are distinct. The 'bankruptcy' hypothesis applies primarily to individuals breeding in poor quality material, especially in species where adults are capable of feeding in living material. It is less likely to apply to species breeding in fresh or living host material. However, when the probability of imminent death is high, any female should convert as much somatic tissue as possible to energy and materials useful for reproduction, regardless of host quality. 'Greener pastures' beckon when microbial activity and mechanical processes (such as drying) degrade the breeding material and when processes independent of beetle activity - summer storms, pathogens, attack of other animals - create new scolytid habitats during the breeding season. This hypothesis is more likely relevant to species breeding in relatively high-quality resources (such as unhealthy or recently-killed hosts) which usually decline in quality more rapidly and more drastically than poor material, and not to species in areas with mild summer climate (few thunderstorms or wind storms) and in hosts not regularly subject to high levels of biological depredations that create new breeding material. There is potential overlap with the 'overcrowding' hypothesis, to the extent that higher beetle densities accelerate degradation processes. 'Overcrowding' frequently occurs in certain breeding situations-e.g. places where many beetles can reproduce simultaneously, due to their small size relative to the amount of material available) - but is perhaps less likely to explain specieswide re-emergence than variations within a population. In branches where crowding does not occur, individual females should oviposit entirely within one gallery system, if re-emergence is primarily due to overcrowding.

\section{Polyandry}

Central to many of the arguments developed here is the requirement that females at least occasionally copulate with more than one male (polyandry). Two lines of evidence suggest that females of the ancestral protoscolytoid-which presumably oviposited through slits in the bark into dead inner bark tissue (e.g. Schedl, 1958; Wood, 1978)-were polyandrous. First, polyandry (or at least multiple matings with the same partner) is characteristic of a wide range of living taxa (references given previously). Second, the probable ecological characteristics of the scolytoid ancestor-favourable oviposition sites patchily distributed and usable by more than one female (generally true of dead inner bark)-would result in the evolution of resource-guarding behaviours in mate-seeking males. Regardless of previous mating history, females copulate with these despotic or territorial males to gain access to the resource and minimize harassment from courting males (discussed in Alcock et al., 1978). Too, females of some ecologically similar beetles (weevils, buprestids, cerambycids) are polyandrous (Michelsen, 1966; Alcock, 1976; Hughes, 1979). I suggest that monandry-reported (accurately?) for Scolytus rugulosus (= Rugoscolytus mediterraneus) in Iran (Chodjai, 1963) and possibly true for several platypodids (e.g. Browne, 1961c, 1962; but see Jover, 1952) - is derived. 
The nature of male-male competition

Direct competition among males for mates does occur in Scolytidae. Most confrontations take place while males are wandering over the bark surface, a relatively brief period for most species. Fighting near gallery entrances has been described for Tomicus piniperda (Salonen, 1973), Hylesinus californicus (Vernoff \& Rudinsky, 1980), Scolytus quadrispinosus (Goeden \& Norris, 1965), Trypodendron lineatum (Fockler \& Borden, 1972), Scolytomimus maculatus (Beaver, 1976a), and Procryphalus mucronatus and Trypophloeus populi (Petty, 1977). Combatants push, butt, and bite, until one is dislodged or driven away. Copulation takes place on the bark surface in Trypodendron lineatum, and males occasionally succeed in prying apart coupled pairs. Males able to enter gallery systems (at least part way) with a male already present are forcibly evicted, as reported for Hylurgops rugipennis (Oester, Ryker \& Rudinsky, 1978), Dendroctonus spp. (McGehey, 1968; Rudinsky \& Ryker, 1976; Ryker \& Rudinsky, 1976a) and Pseudohylesinus nebulosus (Oester, Rudinsky \& Ryker, 1981), and in some instances residents back completely out of the gallery system and the conflict continues on the bark surface (Dendroctonus valens, Ryker \& Rudinsky, 1976a; Scolytus quadrispinosus, Goeden \& Norris, 1965). Once inside, a male cannot be forced out (Oester \& Rudinsky, 1975). In Ips spp., males only move inward to allow females entry if the female stridulates properly (Wilkinson et al., 1967; Barr, 1969; Oester \& Rudinsky, 1975; Swaby \& Rudinsky, 1976). Males are reported to stridulate while fighting in Hylesinus fraxini (Rudinsky \& Vallo, 1979), Dendroctonus spp. (McGehey, 1968; Rudinsky \& Ryker, 1976; Ryker \& Rudinsky, 1976a,b, Pseudohylesinus nebulosus (Oester et al., 1981), Polygraphus rufipennis (Rudinsky, Oester \& Ryker, 1978), and Ips spp. (Oester \& Rudinsky, 1975).

Conflicts between males of Hylesinus oregonus were said to be "difficult to elicit" and the males labelled "not very aggressive" by Vernoff \& Rudinsky (1980)-but they recorded what strikes me as the two most dramatic cases of usurpation in the bark beetle literature. One determined rival "took over 3.75 h to chew a second entrance intersecting the main one below the resident's head, and forced him upwards" - and out of the gallery. A second persistent male "took nearly $1.5 \mathrm{~h}$ to dislodge the resident from the female's entrance by antennating, climbing on and biting him, scratching his declivity, wedging in next to him, and prying him forward by pushing against his sternum".

\section{Conclusions}

'Throughout this section I have assumed that male presence in the entryway of scolytoid gallery system represents a form of mate-guarding: that the behaviour evolved in the context of competition among males for mates and is a means of preventing male rivals from gaining access to the female(s) within. The hypothesis that guarding does function in this manner is easily testable, but the hypothesis that mate-guarding is the primary selective context in which the behaviour evolved will be difficult to establish conclusively.

A different hypothesis is that males may opt to increase the survivorship of offspring in their current gallery systems rather than trying to acquire females elsewhere. Yet another hypothesis is that males gain more eggs through remaining to help dispose of frass (and anything else they may do) and thereby accelerating the oviposition of a female they have fertilized, than by seeking other mating 
opportunities. These are not mutually exclusive possibilities, and, whichever was primary, all may play a part.

Guarding for at least part of a female's oviposition-cycle is the norm in bark and ambrosia beetles. Why? I suggest the following features of scolytoid life predispose them to the evolution of post- (and occasionally pre-) inseminative guarding:

(1) Females will copulate with more than one male.

(2) Females are easily guarded.

(3) Most species breed in aggregations.

(4) High risks attend searching.

(5) Early population OSR (after first flights) is not female-biased.

(6) Early site OSR is male-biased.

(7) Female emergence is usually fairly synchronous.

Brachygamy is the rule, strict monogamy an exception in monogynous systems. This may be because of these additional factors, favouring eventual male abandonment:

(1) Later population OSRs are female-biased.

(2) Male-biased on-site predation and male emigration produce a female-biased site OSR.

(3) Female re-emergence and renewed pheromone production create new mating opportunities for males.

(4) Older females have fewer eggs left to lay, and are probably not easily located by searching males.

Monogamy is rare in this group (and in non-avian animals in general). One would expect to find striking differences from some of the above statements in permanently monogamous bark and ambrosia beetles, of which very little is known at present.

\section{The evolution of male-initiated monogyny}

It is not at all clear to me why male-initiated monogyny is not more prevalent in Scolytidae. Females arriving at potential host material investigate crevices, abandoned gallery starts, and other surface irregularities, and thus some are likely to contact males in gallery starts. By joining a male, they would benefit immensely from getting under the bark quickly, both in terms of reducing vulnerability to predation and being able to begin gallery construction sooner. In addition, the initiating sex risks poisoning or drowning from plant defences such as toxic monoterpene vapours, or flow of gum, latex, or resin-hazards a female could avoid by joining a male rather than starting her own gallery. In a population with female-initiation, the costs and benefits to the males of becoming the initiating sex are not as straightforward. Besides the aforementioned dangers associated with plant defences, it must be borne in mind that females would not be seeking boring males. Initiating males would have to rely on chance encounters with females exploring possible gallery sites. A male digging rather than searching loses time during which he would have had some possibility of encountering a receptive female by searching. Also acting against male initiation becoming established would be protogyny-in female-initiating monogynous species with synchronized breeding, females fly before males, and there may not be many wandering females 
in a site which would encounter a dug-in male. Finally, since within-site femaleinitiated colonization is rapid, and males do not arrive until after females have begun, again there are unlikely to be many wandering females after a male has chewed out an entrance.

Some of the cases of male-initiated monogyny can be explained as a result of monogyny re-evolving in polygynous taxa. Male-initiation, once evolved, should be evolutionarily stable: although fertilized females not finding a male with which they can stay should certainly start their own gallery, the bulk of the population of females will be paired to initiating males, and as long as some males are present only 'excess' females should initiate galleries. Since, as I argue below, maleinitiation should readily evolve in harem polygynous species, I suggest that maleinitiated monogynous Scolytodes might be derived from harem polygynous Scolytodes, and that in monogynous Corthylini such as Pseudopityophthorus, Pityoborus, Pityotrichus, and some Pityophthorus and Araptus (all subtribe Pityophthorina) and most Corthylina genera, monogyny may be secondarily evolved, and maleinitiation conserved if the ancestral corthyline was harem polygynous-not an unreasonable supposition, given the large number of harem polygynous genera in the tribe. Obviously, evidence for or against this hypothesis would best come from detailed phylogenetic analyses of the groups involved.

\section{The evolution of harem polygyny}

Regardless of which sex initiates gallery construction, paired, guarding males must occasionally be approached by females seeking an easy entry under the bark. This should be more common with just-mated males of male-initiated species, but one frequently runs across remarks to the effect that three or four adults (most likely including more than one female) or more specifically that additional females are occasionally found in gallery systems of usually monogynous species (e.g. Rockwood, 1926; Blackman, 1928; Wood, 1958; Smith, 1961 ; Chararas, 1962; Borden, 1969; Beaver, 1972; Gray, 1974; Gruner, 1974; Gray \& Lamb, 1975; Beaver, 1976a; Roberts, 1976; Petty, 1977: almost all are female-initiated species). Thus, there is good evidence that behavioural variability exists in monogynous systems in nature, which when genetically based provides the necessary variation upon which natural selection can act. So, it is appropriate to ask what conditions favour the development of polygynous mating systems.

The question may be divided into two parts: (1) why do females join systems with one or more other females already present? and (2) why do males allow additional females into their gallery systems?.

\section{Why do females join mated males?}

Females should evolve to join mated males if on average females that do so fare better than unpaired females that must initiate their own gallery system, for example if resource quality is highly variable, or if a female-biased sex ratio prevails. Either hypothesis assumes females will make the best choice from among the alternatives facing them; the main difference is that in the OSR hypothesis males are limiting regardless of variations in resource quality, while in the resource quality hypothesis high quality breeding material is in short supply regardless of the number of males available. The two hypotheses are not mutually exclusive.

Resource quality and polygyny. Researchers studying harem polygynous marsh- 
ding birds developed the concept of the polygyny threshold, defined as the mum difference between low- and high-quality territories that allows a female sproduce more successfully with a mated male (e.g. Verner, 1964; Verner \& son, 1966; Orians, 1969; formalized more rigorously by Altmann, Wagner, .enington, 1977). The Verner-Willson-Onians model predicts that increased tat heterogeneity should lead to an increased incidence of polygyny, a liction supported for birds by both within- and among-species comparisons iewed by Wittenberger, 1979: 285f). The model assumes: (1) female fitness is tively correlated with breeding situation quality (resource quality plus male ity); (2) females can in some way assess breeding situation quality; (3) females act appropriately upon their assessments.

arem polygynous scolytids breed primarily in inner bark (most) or wood aracini); all those in Tables $3 \& 4$ are phloeophagous except Monarthrum and iylus, which are xylomycetophagous. The most important aspects of resource ity to female fecundity and to progeny survivorship and ultimate size are sably nitrogen (' $\mathrm{N}$ '), total available carbohydrates ('TAC'), moisture (' $\mathrm{M}$ '), $r$ bark thickness ('IBT'), subcortical temperature, and active or residual plant nces (some relevant papers from the last decade are Safranyik \& Jahren, 1970; :er, 1971; Dyer \& Taylor, 1971; Hodges \& Pickard, 1971; Amman, 1972; Ich \& Roeper, 1973; Smith, 1975; Amman \& Pace, 1976; Berryman, 1976; evitz, 1976; Mizell \& Nebeker, 1978; Webb \& Franklin, 1978, Chararas, 3; Sahota \& Thomson, 1979; Sturgeon, 1979; Wagner et al., 1979; Wright, yman \& Gurusiddaiah, 1979; Wagner et al., 1981).

Iost of the references just given deal with Dendroctonus, and a few deal with the ation encountered by the beetles in nature. One (Hodges \& Pickard, 1971) ents a suggestive correlation (but based on only seven data points) for an effect inner bark carbohydrate content on number of beetles emerging; nan \& Pace (1976) found a possible quality difference between thin and thick $r$ bark of lodgepole pine, affecting adult size and male survivorship of $D$. erosae. Otherwise, there has apparently been no research on $\mathrm{N}$ or TAC content iner bark or wood and their effects on male and female reproductive success ir than my own on Pityophthorus lautus, described below.

tuality parameters such as $N, T A C$, and $M$ in samples from live material (cut re same point in the season) will probably vary little amongst themselves, and Id not be expected to contribute much to explaining variations in reproductive ess in species breeding in living (or very recently killed) inner bark (e.g. sendall, in prep.). But most phloeophagous and xylophagous bark beetles :d in dead material, which would be expected to vary widely in quality (wood laps less than inner bark) due to the variety of biotic and abiotic forces acting lead plant material. The nature of variation in such measures as content of $\mathrm{N}$, ב, or $\mathrm{M}$ will undoubtedly be found to differ from host species to host species, from stage to stage of the decomposition process within each host species. is, beetle species that have evolved specialization on hosts or on specific stages ecomposition will differ in the ranges of resource quality in which they attempt eproduce and hence in the array of resource quality values they regularly face. Ine problem with testing the polygyny threshold model is identifying the rogeneous resource(s) by which females might be choosing among male itories. In phloeophagous and xylophagous scolytids, $\mathrm{N}$ is a prime candidate for ig an important facet of resource quality; woody plant parts are extremely low 
in nitrogenous compounds and $\mathrm{N}$ is frequently limiting in plant-feeding organisms (White, 1978; McNeill \& Southwood, 1978; Mattson, 1980a). Carbohydrates, IBT, and $\mathrm{M}$ content are not difficult to measure, and may also be important.

Several lines of evidence suggest that resource variability leads to variation in reproductive success. First, there are the examples in Table 3 in which harem polygynous species collected from different host species have different maximum and average harem sizes or numbers of arms per gallery system (Polygraphus rufpennis, Ips pini, I. typographus, Orthotomicus erosus, O. suturalis, Pityophthorus consimilis). In each of these cases the samples from different hosts are also from different localities, and other factors influencing harem size (such as population OSR) could have varied besides host species.

Slightly stronger support comes from a recent study of Pityogenes chalcographus in Germany. Führer (1981) bred the beetles, under laboratory conditions, in sections of 20-25-year-old Norway spruce (Picea excelsa) felled at different times of the year, each year from 1976 to 1980 . The more-or-less uniform seasonal fluctuations of egg niche density, larvae produced per unit time, adult progeny per female, and development time were attributed to fluctuations in food value of the inner bark tissue. Führer points out that the four reproductive parameters were strongly depressed in late fall, correlating with the cessation of cambial activity, and that material from some winter-felled trees was unsuitable for brood development.

The only direct measurements of the effects of resource quality on reproductive behaviour and success come from my own research on Pityophthorus lautus (Kirkendall, in prep.). These beetles breed in sumac that has been dead for anywhere from several weeks to over a year; they can occasionally be found reproducing in material sparsely colonized by $P$. lautus the previous season. I measured beginning amounts of $\mathrm{N}, \mathrm{TAC}$, and $\mathrm{M}$, and the IBT, for the dead and fresh pieces mentioned previously. As expected, fresh pieces showed much less variability in $N, T A C$, and $M$, and slightly less in IBT, than dead pieces in which oviposition was attempted (Table 7). Female's response to quality-egg niches $\mathrm{mm}^{-1}$ of gallery arm - varies similarly. Summarizing, the following can be said about $P$. lautus breeding in Rhus glabra $(P<0.05$ for all correlations $)$.

(1) Mean niches $\mathrm{mm}^{-1}\left(\mathrm{n} \mathrm{mm}^{-1}\right)$ of gallery arm is strongly correlated with both $\mathrm{N}$ and TAC, but most highly with a 'quality' index combining the two-the multiple regression of $n \mathrm{~mm}^{-1}$ on $\log \mathrm{N}$ and TAC (' $\mathrm{N}+\mathrm{TAC} \mathrm{Q}$ ' $=1.39(\log$ $\mathrm{N})+0.033(\mathrm{TAC}) ; r^{2}=0.82, n=41$ pieces). IBT and $\mathrm{M}$ contribute nothing to a multiple regression including $\log \mathrm{N}$ and $\mathrm{TAC}$.

(2) Three-quarters of the variation among pieces in mean niches per arm is explained by the variation in $\mathrm{n} \mathrm{mm}^{-1}\left(r^{2}=0.74, n=43\right)$. Females are not simply varying the spacing of broods uniform in number.

(3) Mean niches per gallery system ( $\mathrm{ngs}^{-1}$ ) (i.e. per male), too, is highly correlated with $\mathrm{mm}^{-1}\left(r^{2}=0.65, n=43\right)$, as it is with $\mathrm{N}+\mathrm{TACQ}\left(r^{2}=0.55\right.$, $n=41$ pieces).

(4) $\mathrm{N} \mathrm{gs}^{-1}$ the number of eggs a male gets-depends on (a) the amount of time females spend in his gallery system, female-weeks per male-week $\left(r^{2}=0.75\right.$, $n=23$ pieces in which gallery systems were followed weekly in X-rays), as well as upon how rapidly females reproduce while there (i.e. $\mathrm{n} \mathrm{mm}^{-1}$ ). Since both are strongly correlated with $\mathrm{N}+\mathrm{TAC} \mathrm{Q}$ male reproductive success hinges on resource quality. 
Table 7. Variation in Rhus glabra inner parameters at the time of first gallery initiation by Pityophthorus lautus, and in a measure of female reproductive performance (egg niches $\mathrm{mm}^{-1}$ of gallery arm). Values of nitrogen and 'total available carbohydrates' (TAC) are percentage dry weight: moisture is expressed as percentage of wet weight that is water. $N+T A C Q$ is a combined measure of nitrogen $($ as $\log \mathrm{N})$ and TAC, derived from the multiple regression of niches $\mathrm{mm}^{-1}$ on nitrogen and TAC, using dead pieces only: $N+$ TAC $Q=1.39$ (log $\mathrm{N})+.033(\mathrm{TAC})$. Fresh-freshly dead sumac pieces; dead-dead for a longer but undetermined period of time (potentially several weeks to over a year). Details can be found in Kirkendall (in prep.).

\begin{tabular}{lcccccc}
\hline Varjable & Dead/Fresh & $\mathrm{N}$ & Min. & Max. & Mean & C.V. \\
\hline Nitrogen & Dead & 42 & 0.18 & 3.19 & 0.99 & 76.6 \\
TAC & Fresh & 12 & 0.59 & 1.33 & 0.71 & 29.0 \\
& Dead & 41 & 0.08 & 32.10 & 14.60 & 61.3 \\
Moisture & Fresh & 12 & 24.00 & 32.50 & 28.48 & 9.1 \\
& Dead & 42 & 6.5 & 61.3 & 29.5 & 47.4 \\
Thickness & Fresh & 12 & 43.0 & 60.4 & 52.9 & 10.1 \\
(mm) & Dead & 30 & 0.23 & 0.89 & 0.47 & 39.2 \\
N+TAC Q & Fresh & 12 & 0.36 & 1.08 & 0.58 & 36.2 \\
& Dead & 41 & -.92 & 1.56 & 0.33 & 200.2 \\
Niches mm & Fresh & 12 & 0.59 & 0.98 & 0.73 & 13.7 \\
& Dead & 43 & 0.35 & 2.67 & 1.48 & 47.5 \\
& Fresh & 11 & 1.16 & 2.13 & 1.16 & 14.5 \\
\hline
\end{tabular}

(5) In those pieces in which gallery systems were carefully followed using X-rays, there is no significant correlation between quality or $\mathrm{nmm}^{-1}$ and the number of females per male for gallery systems observed 1 week after the first flights, but after 3 weeks harem size was strongly correlated with both (with $\mathrm{N}+\mathrm{TAC} \mathrm{Q} r^{2}=0.42$ and $n=19$; with $\mathrm{n} \mathrm{mm}^{-1}, r^{2}=0.47$ and $n=20$ ).

(6) The correlations between female-weeks per male-week and resource quality suggests females are capable of assessing resource quality and acting accordingly.

Thus, harem polygyny is better described (in terms of its significance for variance in male reproductive success) by the amount of time females spend in a male's gallery system than by the number of females per male at any one instance, though data in Table 5 suggest there can be strong harem size differences among sets of pieces that (presumably) are extremely dissimilar in inner bark quality.

In essence, then, in Pityophthorus, the only harem polygynous scolytid in which harem dynamics have yet been studied, male reproductive success is determined largely by among-breeding site variations in $\mathrm{N}$ and $\mathrm{TAC}$, and cannot be assayed with confidence by counting females (or gallery arms) at any one point in the season. Rather, a male's reproductive success depends upon how long how many females stay in his gallery system and how well they do there. Female fecundity is higher in pieces rich in both $\mathrm{N}$ and TAC, and larval survivorship (measured as the mean number of progeny per niche) is correlated with resource quality (with $\mathrm{n} \mathrm{mm} \mathrm{m}^{-1}, r^{2}=0.44, n=43$ pieces; with $\mathrm{N}+\mathrm{TAC} \mathrm{Q} r^{2}=0.43, n=41$ ). It remains to be seen how much this picture of harem polygyny in $P$. lautus applies to other harem polygynous species. 
An important aspect of the polygyny threshold model is the very feature that sets harem polygyny apart from the more commonly encountered mating system of sequential polygyny: females simultaneously paired to the same male potentially interact. Altmann et al. (1977) present two versions of the polygyny threshold model: the competitive female choice model, and the co-operative female choice model. If within-harem competitive interactions take place in scolytids (among larvae for food, or among adults perhaps for the frass-removal services of the male) female fitness is reduced by the presence of other females in the harem. Joining a mated male could benefit the joining female if there are 'co-operative' effects or if there is a 'selfish herd' effect (Hamilton, 1971): more larvae per unit area might mean fewer parasitized or predated offspring for an individual female.

Competitive effects have not been studied in harem polygynous species of Scolytidae. The effects of resource quality and of variations in density complicate the determination (in field studies) of whether or not female behaviour is affected by harem size, or larval survivorship is significantly decreased by competition with offspring from the same harem. For example, increases in survivorship due to resource quality parallel (up to a point) increases in numbers of eggs laid in gallery systems. Thus far, analyses of my $P$. lautus data have not revealed significant within-harem effects, but overall density within a ramet piece does affect survivorship when quality is high (Kirkendall, in prep.). Investigations using isolated gallery systems under controlled conditions are needed; my preliminary experiments with isolated harems of various sizes were stymied by increased female re-emergence from large harems. Similar confounding of variables makes testing a 'selfish herd' hypothesis difficult at the level of the harem; I found a low but significant correlation between parasitoid emergence per niche and niche density in ramet pices (Kirkendall, in prep.).

The polygyny threshold model predicts that monogynous species may be so because the resource quality is relatively homogeneous. Dendroctonus and other taxa adapted to colonizing living tissue face host quality that, as mentioned above, probably varies relatively little in most parameters. On the other hand, dead phloem of some host species may always be rather low in nutrients, and bark beetles breeding in those hosts may be monogynous at least partly as a result of what I call the geometric constraint hypothesis. Phloeophagous beetle larvae feed largely in two dimensions, utilizing a more-or-less oval region around a gallery arm. The poorer in nutrients or thinner the inner bark, the further larvae must tunnel to acquire the minimum amount of nutrition necessary to become an adult, and hence the larger the resource-utilization oval relative to the length of the egg arm. Overlap between such ovals results in larval mortality due to intraspecific competition leading to starvation or incidental cannibalism.

Intraspecific competition is probably the primary cause of larval mortality in most monogynous phloeophagous bark beetles (e.g. McMullen \& Atkins, 1961 ; Cole, 1967; Amman, 1972; Berryman \& Pienaar, 1973 and refs; Cole, 1973; Beaver, 1974b and refs). In species with large, oval resource-utilization areas, overlap caused by the addition of one more gallery arm coúld mean that the new female would suffer a significant decrease in reproductive success compared to mating with an unmated or less-polygynous male in similar quality inner bark: the poorer the resource, the more overlap, and the higher the cost to joining. Comparing monogynous and harem polygynous species with respect to the size of resource-utilization areas relative to arm length or beetle size might provide a test 
of the geometric constraint hypothesis for the 'non-evolution' of harem polygyny in phloeophagous Scolytidae. It may be relevant to point out here that woodboring beetles such as Micracini breed in a three-dimensional environment, and hence female reproduction may not be so strongly affected by presence of another female even in the low quality resource that wood should be.

Sex ratio and harem polygyny: One of the hypotheses for harem polygyny in birds (since shown to be of limited application) is that it results from a shortage of sexually-mature males (discussed by Verner, 1964 and Orians, 1969, among others). In bark beetles, pupal, teneral adult, and emergence sex ratios usually do not deviate significantly from $1: 1$. This is true of harem polygynous species in Hylesinus (Chararas, 1962), Ips (Seitner, 1923, cited by Schwerdtfeger, 1929 and by Salonen, Pulliainen \& Koponen, 1968, but not seen by me; Thomas, 1961; Annila, 1971, laboratory-reared), Pityogenes (Schwerdtfeger, 1929; Chararas, 1962; Hamilton, 1979), Pityokteines (Chararas, 1962), Pityophthorus (see below), and Corthylus (Kabir \& Giese, 1966). Slightly (but statistically significant at $P<0.05$ ) female-biased sex ratios have been recorded for $I$. confusus callow adults $\left(46^{\circ}\right.$, male: Cameron \& Borden, 1967), I. typographus emerging adults in three localities over two different years (mean $44^{\circ}$ male: Annila, 1971 ; cf. Seitner, 1923) and Pityokteines sparsus emerging brood after overwintering as adults or larvae $(40 \%$ male: Hosking \& Knight, 1976). The sampled populations of these species apparently sustained differential larval mortality, as Williams (1966) predicted could sometimes be expected in highly polygynous organisms. A more puzzling case is that of the male-initiated xylomycetophagous Monarthrum fasciatum breeding harem polygynously in Ouercus; Roling \& Kearby (1974) working in Missouri collected about 1400 beetles from emergence traps, of which only $33 \%$ were males - a figure that seems too extreme to be explained by differential mortality of the sort mentioned above, especially since egg-to-adult mortality is generally quite low in ambrosia beetles (e.g. Browne, 1961a; Beaver, 1977).

With the exception of $M$. fasciatum, the reported gallery system sex ratios (Table 3) are usually considerably more biased than the emergence sex ratios of harem polygynous scolytids - a fact that has intrigued generations of forest entomologists. Conflicting data and speculations culminated in the careful observations of Schwerdtfeger (1929), who methodically tested a variety of hypotheses that had been put forth to explain the relative deficiency of breeding males in harem polygynous bark beetles. After conducting a series of collections of Pityogenes chalcographus throughout the winter and into the spring, Schwerdtfeger confirmed the findings of earlier researchers to the effect that young adults are equally divided in gender, and established that overwintering mortality was not biased. Based on these findings and laboratory observations during the breeding season, he concluded that the only plausible hypothesis to account for the strong female bias in gallery systems was that a large proportion of males went unmated.

Annila (197I) set out to investigate this problem of the 'missing males' in $I$. typographus in Finland, and found that the sex ratio bias seen during active gallery construction resulted from a more gradual diminution of males. Males constituted $48 \%$ of unemerged adult progeny; $44 \%$ of emerging adults; $40 \%$ of those caught by window traps during the flights; and $32 \%$ of parents in gallery systems. (Over 30000 beetles were sexed during this study.)

Unfortunately, one must use caution in interpreting sex ratios based on collections from gallery systems of harem polygynous species. Such sampling will 
almost always be more female-biased than the actual population sex ratio, unless steps have been taken to randomize the procedure by which branches, logs, or other host material containing the beetles is collected. Otherwise, samples will inevitably be biased towards more densely (= noticeably) colonized material; such breeding material may well be of relatively high resource quality and thus have more females per male than the population average, or simply have more females per male if many isolated pheromone sources are not locatable (this will depend on the distribution and density of pheromone sources and of flying beetles). In some instances it may well be that the vast majority of individuals are in densely colonized material, but unless this is known to be true the relationship of sex ratio of 'noticeable' material to that of the population is not clear. My experimental pieces were cut before flights took place, thus avoiding this problem of inadvertently collecting only medium-to-high density samples. Perhaps this is why the gallery system sex ratios in Fig. 4 seem low for a scolytid that does not otherwise strike the observer as being only mildly polygynous.

Trap collections, too, are suspect. Field biologists of all persuasions will attest that trapping animals measures activity, and conclusions as to the underlying population sex ratio must be weighted by an understanding of sex-specific differences in behaviour. For example, during the first few major flights of 1979 , 1980 , and $1981,88^{\circ}$ of $801 P$. lautus collected wandering on dead sumac $1 \mathrm{~h}$ or more after mass flights began (in early evening) were males; $60_{0}^{\circ}$ of 583 beetles caught in window traps during the first month of flights were males; while males made up only $48 \%$ of 2068 reared individuals ( 1980 \& 1981 only). Meanwhile, gallery system analyses revealed that about $42-48 \%$ of gallery occupants were male (Fig. 3). Males have to find good spots for beginning to tunnel, while females need only gain entrance to gallery systems already started. Thus males are found walking on the surface over a much longer period of time than females. Habitats 'fill up' more rapidly for males than for (polygynous) females (see Fig. 3).

The immediate concern is whether there is an unbalanced population OSR that could lead to some females being 'forced' to join mated males (if the males will have them). It is probable that although roughly equal numbers of each sex begin the flight season, there is indeed higher mortality to males very early on: males are both the initiating sex (in some monogynous and almost all harem polygynous species), and the guarding sex, and both are hazardous roles. For this reason, one would expect that as the season progresses the OSR should become more and more biased towards females, which should provide some impetus towards harem polygyny, but the magnitude of the difference between male and female mortality during this period remains to be ascertained (just as do actual gallery system sex ratios).

\section{Why do mated males allow joining?}

Mated males should allow entry except when an additional female will decrease the number of expected progeny; but in such a case the cost to the joining female could be great enough to deter joining, if harem size is somehow detectable by the incoming female. Potentially, adding one arm to a well-ordered gallery system could create such chaos-perhaps from the additional larvae forcing other larvae to deviate from their 'shoulder-to-shoulder' paths--as to cause a precipitous decline in the productivity of the resource around the gallery system. Whether 
females would try to join in such a situation is not clear; were the alternative not reproducing at all, presumably they would.

There is evidence that males in some species do behave in such a way as to limit access to their gallery systems. Ips paraconfusus males sometimes actively reject courting females: of 40 males that readily accepted a third female, 20 refused to allow a fourth to join, though the females pushed and stridulated vigorously (Borden, 1967). In addition, Borden found that the attractancy of frass from mated males varied inversely with the number of females in the gallery systems (for up to three females). Vité, Bakke \& Renwick (1972) report that male I. calligraphus that have been joined by three or more females quickly cease to synthesize the frass pheromone ipsdienol. There are several other cases in which males lose attractiveness after acquiring females (Chararas, 1969; Chararas \& M'Sadda, 1970; Werner, 1972; Swaby \& Rudinsky, 1976), but the likelihood of females producing 'masking' or 'anti-aggregative' odours (e.g. Rudinsky, 1969; Nijholt, 1970, 1973; Rudinsky, et al., 1973; Borden, 1974a) cannot be eliminated in these cases.

I know of only one mention that guarding males of monogynous species do or do not allow second females to enter their gallery systems. Jover (1952) observed that platypodid males (he does not say which species) courted by a second female reacted the same as bachelor males, by backing out of the gallery start, allowing the female to enter, and re-entering the tunnel. However, Jover reports that the second female soon forces the male back out, exits the hole and flies away.

\section{The evolution of male initiation}

When circumstances strongly favour harem polygyny, as by one of the scenarios described above, the evolution of male-initiation seems almost certain. If the cost to joining is less than the cost to initiating, selection favours those females that wait and join males rather than initiate their own gallery system. Males starting a hole would then be sought out by females. The evolution of male-initiation could begin with females joining males that were in preflight or pre-mating feeding tunnels, or joining males exhibiting 'female' digging behaviour, or simply males investigating abandoned starts, and any slight changes in male behaviour that led to males chewing out entrances would spread if such males were likely to acquire more females than males joining initiating females.

Two examples of 'intermediate' stages in this model are known, and deserve further careful research. Females initiate gallery construction in Hylesinus varius, a European ash bark beetle. (Related North American and European species have female-initiated monogynous mating systems: Graf, 1977; Rudinsky \& Vallo, 1979; Rudinsky \& Vernoff, 1979; Vernoff \& Rudinsky, 1980.) According to Rudinsky \& Vallo (1979: 426f): “. . . it appears that one female enters the host bark first, followed by a male, then a second female. After mating with each female in one branch of the biramous gallery, the male apparently leaves. When the male was with only one female, we found it guarding the entrance . . whereas the female was guarding the entrance when there were two females alone or two females with one male." Of 50 gallery systems they dissected on the same day, 13 had only a female (no eggs present), 10 had one female and one male, 12 had two females and a male, and 15 had two females but no male (eggs present); the subsequent dissection of 50 gallery systems 10 days later revealed over threequarters (39) had two females and no male, six had two females plus a male, and 
the remainder divided between the other two categories. Using two logs with males and two with females, each infested with 25 beetles "collected directly from ash logs under attack", they found 226 of 232 trapped beetles were attracted to logs with females, in this Slovakian population. Earlier, Schönherr (1970) had reported on a brief study of this species in West Germany: 511 beetles were attracted to a $\log$ with 50 males, 43 to a $\log$ with 50 females, and 44 to an uninfested $\log$. No mention is made of how or when the 100 individuals used in the experiment were collected. There are three possible explanations for the contradictory results: (a) the populations differ in which sex produces the attractant; (b) someone mis-sexed the experimental beetles; or (c) we have a 'six blind men and the elephant' situation, wherein each brief study observed a different part of the mating system. Since (a) is not known to occur in any organism, and both studies were designed specifically to investigate the roles of the sexes in 'mass attraction', I find (c) the most attractive explanation. I suggest that, as is common for the subfamily Hylesininae (e.g. Borden et al., 1975), the initiating females produce attractants as they begin their gallery systems; mated females cease to produce attractant, but the possibility of bigyny has led to the evolution of males producing pheromone aimed at attracting second femalesproduction of which is triggered after entering a gallery system. If this is true, then Schönherr's beetles must have been removed from gallery systems, and the Slovakian beetles collected from log surfaces.

The second example of a likely transitional species is also from the Hylesininae, from its one tribe which is largely harem polygynous. Stimulated by conflicting claims as to which sex starts the gallery in Polygraphus rufipennis, Rudinsky et al. (1978) carefully investigated the question and reported that galleries can be started by either sex, a phenomenon that has not been recorded for any other scolytid. Significantly, however, only males actually construct nuptial chambers beneath entrance tunnels; females join (= locate?) single males more often than males join single females; and starts with males are more frequent than starts with females. To me, $P$. rufipennis appears to be a species in transition from female-initiated to maleinitiated harem polygyny. The nearly indistinguishable $P$. poligraphus, a European species, is reported as having male-initiated harem polygyny (Chararas, 1962). Carphoborus, the other polygraphine genus thought to be entirely harem polygynous, is more strongly polygynous (Table 3) and again it is males that initiate (Wood, 1954b; Chararas, 1962, 1966). Males initiate in Chortastus agnatus Egg., which appears to be harem polygynous with one to four arms per gallery system; C. camerunus Schauf. and C. similis Egg. are said to be monogynous (Schedl, 1959).

\section{Tests and conclusions}

Some interesting testable predictions arise from the geometric constraint version of the polygyny threshold model; those involving beetle size (1-3, below) assume that, for a given resource quality, larger adults result from more larval feeding and thus longer larval mines, producing a larger resource-utilization oval. (1) For a given region (roots, bole, branches, twigs, etc.) and a given feeding mode:

(a) when monogyny and harem polygyny are both present in a host species, the monogynous species will be the largest; 
(b) if monogyny, bigyny, and harem polygyny are all present in a host species, adult size will be ordered $\mathrm{M}>\mathrm{B}>\mathrm{HP}$.

(2) Within a scolytid genus, the largest species will be the least polygynous, when congeners inhabit the same or similar host species and similar regions and tissues. (3) Where bark beetles are similar in size and feeding mode but differ in mating systems, beetles in small diameter material will be less polygynous (due to spatial considerations).

(4) Species colonizing dead material should be more highly polygynous in hosts that vary more in quality; heterogeneity in breeding sites should be greater in host tissues that are higher in resource quality when alive (i.e. that start out higher).

While I do not expect these predictions to hold true in every instance, I do believe that whenever resource quality is important in the ways which have been discussed here, these predictions will hold for general trends.

Female-biased operational sex ratios are likely to be found in many bark beetles-especially in male-initiating groups-including all harem polygynous species, but the mere predominance of females in a harem polygynous taxon does not alone support an OSR hypothesis for the origin of harem polygyny in that lineage. Support for the OSR model would be indicated if resource heterogeneity were shown not to be important, and females joining mated males suffered reduced reproductive success. Neither condition alone is sufficient. By the polygyny threshold model, females joining mated males could ultimately do better than, as well as, or worse than females pairing with males with fewer or no females; the model predicts only that she makes the best choice available at the time (Altmann et al., 1977, discuss this point thoroughly).

The key to understanding harem polygyny in Scolytidae may lie in the synergy of two approaches: comparison of successful and unsuccessful individuals within species, and comparison of bigynous species with their monogynous congeners. Knowledge of within- and among-host variability in breeding material quality is essential to advancing our understanding of the role of resource quality in the evolution of polygynous mating systems. Observing the behaviour of individuals should be possible with larger species despite their subcortical habits, if beetles can be marked with an X-ray-opaque substance; even without marking individuals, however, serial radiography can reveal much about harem dynamics. Understanding more about harem polygyny could, in turn, tell us why monogynous species have remained so.

\section{The evolution of inbreeding polygyny}

Most inbreeding polygynous Scolytidae are virtually asexual both from a population genetics standpoint and with respect to reproductive rate. Progeny are nearly all female and therefore have almost twice the reproductive potential as comparable, sexually produced half-male broods. Despite the apparent cost to sexuality of wasting resources on producing males, most organisms-including most scolytid lineages - are sexual. Thus, the question of the evolution of inbreeding grades into perhaps the most important unanswered question in biology, that of the evolution and maintenance of sex. A sufficient discussion of that topic would enlarge this paper beyond reasonable limits. Recent general discussions of the problem of sexual $v$. asexual reproduction may be found in 
Williams, 1975; Maynard Smith, 1978; Hamilton, 1980; Lloyd, 1980. Therefore, although inbreeding polygyny characterizes a large portion of the world scolytid fauna, and certainly constitutes an important mating system, I will discuss its evolution only briefly here.

Inbreeding in scolytids has arisen in lineages feeding in a variety of resources: mutualistic fungi, inner bark, pith, and seeds and fruits (Table 6). With the possible exception of spermatophagy (a rare feeding mode among scolytid genera), all of these habits are shared with numerous outbreeding bark and ambrosia beetles. $\Lambda$ n especially interesting comparison is between Xyleborus and Platypodidae. Both are frequently abundant in tropical forests, and various species of each can often be found in the same log: Xyleborus species are all inbreeding polygynous and the mother constructs the gallery system by herself; almost all platypodids are monogamous, and females have never been recorded as successfully breeding alone. No one has described any obvious differences in the ecology of these two groups (some general comparative data can be found in Webb \& Jones, 1957), though this may be a function of the difficulty of studying insects which bore into the centre of large trees.

'The one generalization that can be made regarding the multiple origins of inbreeding polygyny in Scolytidae is that each case some factor(s) must have initially favoured females copulating before leaving their natal host material. This is rather easily accomplished, since individuals usually mature in close proximity to others. In fact, a low incidence of mating before dispersal is known for several outbreeding taxa, including Dendroctonus ponderosae (McCambridge, 1969), Ips grandicollis (All \& Anderson, 1972; Witanachchi, 1980) and Cryphalus (as Taenioglyptes: Wood, 1954a).

In one possible route to inbreeding polygyny, the presumed costs from inbreeding-lowered offspring viability and fecundity-must have been outweighed by the benefits of increased colonizing ability resulting from no longer needing to attract a male for copulation. By another scenario, lowered dispersal made possible by local renewable resources (seed, twigs) leads to inbreeding within small demes (see Stenseth, 1980). By any sequence, the lineages seem to have escaped not only short- but long-term selective pressures favouring sexuality, judging from the complex of behavioural and morphological adaptations to inbreeding associated with those taxa-- or else such pressures have been held at bay by occasional outbreeding.

\section{CONCLUDING REMARKS}

I have not attempted an exhaustive review of scolytoid breeding habits; rather, this paper is intended to highlight patterns of bark and ambrosia beetle mating systems and to draw attention to the major inadequacies of our knowledge. As is obvious from my bibliography, my efforts have been confined largely to publications in English, French, and to a much lesser extent German. Undoubtedly, important additional information could yet be gleaned from other primary literature of Europe and Asia.

A source of misgivings in daring to conceive and in executing this review, has been the woeful lack of information on male behaviour and on the nature of bigyny and other forms of harem polygyny, making even the categorization of bark and ambrosia beetle mating systems hazardous. On the other hand, these gaps also 
provide powerful motivation for presenting a preliminary synthesis. It is my strong conviction that the diversity of habits in this group will prove fascinating to a wider audience than previously, and my hope that this review will spur further research into the topics I have touched on here.

\section{ACKNOWLEDGEMENTS}

I wish to thank R. D. Alexander, M. Deyrup, W. D. Hamilton, B. Low, M. M. Martin, T. E. Moore, N. Moran, and S. L. Wood for their comments on various drafts. Nancy Moran helped considerably with both theoretical and practical matters. Stephen L. Wood and Mark Deyrup kindly allowed me to cite unpublished observations, and Christine Hamilton provided me with a translation of the Schwerdtfeger article. I am especially grateful to the many authors who provided me with reprints of their work, and to the University of Michigan's interlibrary loan system for their help in obtaining some of the more obscure references cited herein.

This paper is part of a dissertation submitted in partial fulfillment of the requirements of the Ph.D. in Biological Sciences at the University of Michigan. The research on Pityophthorus lautus was supported by funds from the University of Michigan Rackham School of Graduate Studies, the U. M. Division of Biological Sciences, and the U. M. Museum of Zoology.

\section{REFERENCES}

ALCOCK, J., 1976. Courtship and mating in Hippomelas planicosta (Coleoptera: Buprestidae). Coleopterists Bulletin, 30: $343-348$.

ALCOCK, J., BARROWS, F. M., GORDH, G., HUBBARD, L. J., KIRKENDALL, L., PYLE, D. W., PONDER, T. L. \& ZALOM, F. G., 1978. The ecology and evolution of male reproductive behaviour in the bees and wasps. Zoological Journal of the linnean Society, fi4: 293-326.

ALL, J. N. \& ANDERSON, R.F, 1972. Initial attack and brood production by females of Ips grandicollis (Coleoptera: Scolytidae). Annals of the Entomologicat Society of America, 65: 1293-1296.

ALTMANN, S. A., WAGNER, S. S. \& LENINGTON, S., 1977. Two models for the evolution of polygyny. Behavioral Ecology and Sociobiology, 2: 397410

IMMAN, G. D., 1972. Mountain pine beetle brood production in relation to thickness of lodgepole pine phloem. Journal of Economic Entomology, 65: 138140.

IMMAN, G, D. \& PACE, V. E., 1976. Optimum egg gallery densities for the mountain pine beetle in relation to lodgepole pine phloem thickness. U.S. D. A. Forest Service Research Vote INT-209, 8 pp.

INNILA, E., 1971. Sex ratio in Ips typographus L. (Col., Scolytidae). Annales Entomologica Fennica, 37: 714.

ISHRAF, M. \& BERRYMAN, A. A., 1969. Biology of Scolytus ventralis (Coleoptera: Scolytidae) attacking Abies grandis in northern Idaho. Melanderia, 2: 11-23.

3ALACHOWSKY, A, 1949. Coléoptères Scolytidae. Faune de France, 50:320 pp.

3ALL, J. C. \& DAHLSTEN, D. L., 1973. Hymenopterous parasites of $1 /$ s paraconfusus (Coleoptera : Scolytidae) Jarvae and their contribution to mortality. I. Influence of host tree and tree diameter on parasitization. Cianadian Entomologist, 105: 1453 1464.

BALOGLN, R. A., 1970. The larch bark beetle, Ips cembrae (Coleoptera: Scolytidae), in the north-east of Scotland. Canadian Entomologist, 102: 226 239

ARR, B. A., 1969. Sound production in Scolytidae (Coleoptera) with emphasis on the genus Ips. Canadian Entomologist, 101: 635-672.

ARRAS, S. J. \& PERRY, T. J., 1975. Interrelationships among microorganisms, bark or ambrosia beetles, and woody host tissue: an annotated bibliography, 1965 197. U. S. D. A. Forest Service General Technical Report SO10: $34 \mathrm{pp}$.

AR'TELS, J. M. \& LANIER, G. N., 1974. Emergence and mating in Scolytus multistriatus (Coleoptera: Scolytidae). Annals of the Entomological Society of America, 67: 365370.

AR'ILETT, A. C., MATTIX, E. B. \& WILSON, N. M., 1968. Multiple matings and use of sperm in the boll weevil, Anthonomus grandis. Annals of the Entomological Society of America, 61: $1148-1155$.

EilYR, R. A., I966a. Notes on the biology of bark bectles attacking elm in Wytham Wood, Berks. Entomologists Monthly Magazine, 102: 156 162. 
BEAVER, R. A., 1966b. The biology and immature stages of Entedon leucogramma (Ratzeburg) (Hymenoptera: Eulophidae), a parasite of bark beetles. Proceedings of the Royal Entomological Society of London (A), 41:37-41.

BEAVER, R. A., 1972. Biological studies of Brazilian Scolytidae and Platypodidae (Coleoptera). I. Camptocerus DeJean. Bulletin of Entomological Research, 62: 247-256.

BEAVER, R. A., 1973a. Biological studies of Brazilian Scolytidae and Platypodidae (Coleoptera). II. The tribe Bothrosternini. Papeis Avulsos Zoologia, S. Paulo, 26: 227.236.

BEAVER, R. A., 1973b. Biological studies of Brazilian Scolytidae and Platypodidae (Coleoptera). III. The tribe Hylesinini. Journal of Vatural History, 7: 601-613.

BEAVER, R. A., 1974a. Biological studies of Brazilian Scolytidae and Platypodidae (Coleoptera). IV. The tribe Cryphalini. Studies on the Neotropical Fauna, 9: $171-178$.

BEAVER, R. A, 1974b. Intraspecific competition among bark beetle larvae (Coleoptera: Scolytidae). Journal of Animal Ecology, 43: 455-467.

BEAVER, R. A., 1976a. The biology of Samoan bark and ambrosia beetles (Coleoptera: Scolytidae and Platypodidae). Bulletin of Entomological Research, 65: 531548.

BEAVER, R. A., 1976b. Biological studies of Brazilian Scolytidae and Platypodidae (Coleoptera). V. The tribe Xyleborini. Zeitschrift für angewandte Entomologie, 80: 15-30.

BEAVER, R. A., 1977. Bark and ambrosia beetles in tropical forests. Proceedings of the Symposium on Forest Pests $\mathcal{E}^{\circ}$ Diseases in Southeast Asia, Bogor, Indonesia, April 1976, BIOTROP Special Publication, 2: 133-147.

BEAVER, R. A., 1979a. Leafstalks as a habitat for bark beetles (Col.: Scolytidae). Zeitschrift für angeurandte Entomologie, 88: 296-306.

BEAVER, R. A., 1979b. Non-equilibrium 'island' communities. A guild of tropical bark beetles. Journal of Animal Ecology, 48: 987-1002.

BEAVER, R. A., 1979c. Host specificity of temperate and tropical animals. Nature, 281: 139-141.

BEAVER, R. A. \& BROWNE, F. G., 1975. The Scolytidae and Platypodidae (Coleoptera) of Thailand, a checklist with biological and zoogeographical notes. Oriental Insects, 9:283-311.

BEAVER, R. A. \& BROWNE, F. G., 1978. The Scolytidae and Platypodidae (Coleoptera) of Penang, Malaysia. Oriental Insects, 12: 575-624.

BECKF, G., 1971. Physiological influences on wood-destroying insects of wood compounds and substances produced by microorganisms. Wood Science and Technology, 5: 236-246.

BEEMAN, S. L. \& NORRIS, D. M., 1977. Embryogenesis of Xyleborus ferrugineus (Fabr.) (Coleoptera, Scolytidae). I. External morphogenesis of male and female embryos. Journal of Morphology, 152: 177219.

BEESON, C. F. C., 1941. Forest Insects of India and the Neighboring Countries. Dehra Dun: published by the author.

BELYEA, R. M., 1952. Death and deterioration of balsam fir weakened by spruce budworm defoliation in Ontario. Part I. Notes on the seasonal history of insects breeding in severely weakened and dead trees. Canadian Entomologist, 84: 325-335.

BERGAMIN, J. \& KERR, W. E., 1951. Determinação do sexo e citologia da broca do café. Ciencia e Cultura, 3 $117-121$.

BE.RISFORD, C. W., 1974. Parasite abundances in I $p s$ spp. infestations as influenced by the southern pine beetle. Environmental Entomology, 3: 695-696.

BERRYMAN, A. A., 1976. Theoretical explanation of mountain pine beetle dynamics in lodgepole pine forests. Environmental Entomology, 5: 1225-1233.

BERRYMAN, A. A. \& PIENAAR, L. V., 1973. Simulation of intraspecific competition and survivial of Scolytus ventralis broods (Coleoptera: Scolytidae). Environmental Entomology, 2: 447-459.

BIRCH, M. C., 1978. Chemical communication in pine bark beetles. American Scientist, 66: 409-419.

BLACKMAN, M. W., 1915. Observations on the life history and habits of Pityogenes hopkinsi Swaine. New York State College Forestry Technical Bulletin, 2: 11-66.

BLACKMAN, M. W., 1919a. Notes on forest insects. I. On two bark-beetles attacking the trunks of white pine trees. Psyche, 26: 85-96, pl. IV.

BLACKM $\bar{N}$ N, M. W., 1919b. Notes on forest insects. II. Notes on several species of Pityophthorus breeding in the limbs and twigs of white pine. Psyche, 26: 134-142, pls. VII-IX.

BLACKMAN, M. W., 1920. Notes on forest insects. III. Two new species of Pityophthorus from Colorado. Psyche, 27: $1-5$,

BLACKMAN, M. W., 1922a. Mississippi bark beetles. Mississippi Agricultural Experiment Station Technical Bulletin, 11: 1-130, pls. I-XVIII.

BLACKMAN, M. W., 1922b. New species of Ipidae from Maine. Papers of the Department of Forest Entomology, Syracuse University, 22: 117-136.

BLACKMAN, M. W., 1928. The genus Pityophthorus Eichh. in North America: A revisional study of the Pityophthori, with descriptions of two new genera and seventy-one new species. Bulletin of the New York State College of Forestry at Syracuse University Technical Publication 25: $183 \mathrm{pp}$.

BLACKMAN, M. W., 1942. Revision of the genus Phloeosinus Chapuis in North America (Coleoptera, Scolytidae). Proceedings of the United States National Museum, 92: 397-474, pls. 38-41.

BLACKMAN, M. W. \& STAGE, H. H., 1918. Notes on insects bred from the bark and wood of the American larch. New York State College of Forestry Syracuse University Technical Publication, 18: 11-115.

BLACKMAN, M. W. \& STAGE, H. H., 1924. On the succession of insects living in the bark and wood of dying, dead and decaying hickory. New York State College of Forestry Syracuse University Technical Publication, 17: 3- 269. 
BLANDFORD, W. F. H., 1904. Family Scolytidae. In Biologia Centrali-Americana, Insecta, Coleoptera, Vol. 4, pt. 6: $225-280$.

BOORMAN, E. \& PARKER, G. A., 1976. Sperm (cjaculate) competition in Drosophila melanogaster, and the reproductive value of females to males in relation to female age and mating status. Fcological Entomology, 1: 145155.

BORDEN, J.H., 1967. Factors influencing the response of Ips confusus (Coleoptera: Scolytidae) to male attractant. Canadian Entomologist, 99: 11641193.

BORDEN, J. H., 1969. Observations on the life history and habits of Alniphagus aspericollis (Coleoptera: Scolytidael in southwestern British Columbia. Canadian Entomologist, 101: 870-878.

BORDEN, J. H., 1974a. Pheromone mask produced by male Trypodendron lineatum (Coleoptera: Scolytidae). Canadian Journal of Zoology, 52: 533-536.

BORDEN, J. H., 1974b. Aggregation pheromones in the Scolytidae. In M. C. Birch (Ed.), Pheromones: 135-160. Amsterdam: North-Holland Publishing Company.

BORDEN, J. H. \& FOCKLER, C. E., 1973. Emergence and orientation behavior of brood Trypodendron lineatum (Coleoptera: Scolytidae). Journal of the Entomological Society of British Columbia, 70: $34-38$.

BORDEN, J. H. \& KING, C. J., 1977. Population aggregation pheromone produced by male Scolytus scolytus (F.) (Coleoptera: Scolytidae). Forestry Commission Research and Development Paper, 118: 1-8.

BORDEN, J. H., VANDERSAR, T. J. \& STOKKINK, E., 1975. Secondary attraction in the Scolytidae: an annotated bibliography. Simon Fraser University Pestology Centre Pest Management Paper, No. 4: v $+97 \mathrm{pp}$.

BORGIA, G., 1979. Sexual selection and the evolution of mating systems. In M. S. \& N. A. Blum (Eds.), Sexual Selection and Reproductive Competition in Insects: 19-80. New York: Academic Press.

BRIGHT, D. E., 1963. Bark beetles of the genus Dryocoetes (Coleoptera: Scolytidae) in North America. Annals of the Entomological Society of America, 56: 103-115.

BRIGHT, D. E., 1967. A review of the genus Cactopinus, with descriptions of two new species and a new genus (Coleoptera: Scolytidae). Canadian Entomologist, 99: 917 7 925.

BRIGHT, D. E., 1968. Review of the tribe Xyleborini in America north of Mexico. Canadian Entomologist, 100: $1288-1323$.

BRIGHT, D. E., 1976. The insects and arachnids of Canada. Part 2. The bark beetles of Canada and Alaska (Coleoptera: Scolytidae). Canada Department of Agriculture Publication 1576: $241 \mathrm{pp}$.

BRIGHT, D. E., 1981. Taxonomic monograph of the genus Pityophthorus Eichhoff in North and Central America (Coleoptera: Scolytidae). Memoirs of the Entomological Society of Canada, 118:1-378.

BRIGHT, D. E. \& STARK, R. W., 1973. The bark and ambrosia beetles of California (Coleoptera: Scolytidae and Platypodidae $>$. Bulletin of the California Insect Survey, 16: $169 \mathrm{pp}$.

BROWNE, F. G., 1961a. The biology of Malayan Scolytidae and Platypodidae. Malayan Forest Rerords 22. $1-255$.

BROWNE, F. G., 196lb. The generic characters, habits and taxonomic status of Premnobius Eichh. (Coleopt., Scolytidae). Fourth West African Timber Borer Research Unit Report, 1961: 45 51.

BROWNE, F. G., 1961c. Preliminary observations on Doliopygus dubius (Samps.), (Coleoptera: Platypodidae). Fourth West African Timber Borer Research Unit Report, 1961: 15-30.

BROWNE, F, G., 1962e. The emergence, flight and mating behavior of Doliopygus conradti (Strohm.), (Coleoptera: Platypodidae). Fifth West African Timber Borer Research Unit Report, 1962: 21-27.

BROWNE, F. G., 1962b. Two new genera of the Scolytidae (Coleoptera). Fifth West African Timber Borer Research Unit Report, 1962: 75-80.

BROWNE, F. G., 1963a. Notes on the habits and distribution of some Ghanaian bark beetles and ambrosia beetles (Coleoptera: Scolytidae and Platypodidae). Bulletin of Entomological Research, 54: 229 -266.

BROWNE, F. G., 1963b. Taxonomic notes on Scolytidae (Coleoptera). Entomologische Berichten, 23: 53-59.

BROWNE, F. G., 1971. The African species of Scolytoplatypus Schaufuss (Coleoptera: Scolytidae). Review Africana, 84: $111-129$.

CACHAN, P., Les Scolytoidèa mycetophages des forêts de basse, Côte d'Ivoire: problèmes biologiques et écologiques. Revue de Pathologie V'égétale, 36: 12-53.

CAMERON, E. A. \& BORDEN, J. H., 1967. Emergence patterns of Ips confusus (Coleoptera: Scolytidae) from ponderosa pine. Canadian Entomologist, 99: 236-244.

CAMPANELLA, P. J. \& WOLF, L. L., 1973. Temporal leks as a mating system in a temperate zone dragonfly (Odonata: Anisoptera), I: Plathemislydia (Drury). Behaviour, 47: 4-87.

2HAMBERLIN, W. J., 1917. An annotated list of the scolytid beetles of Oregon. Canadian Entomologist, 49: $321348,353-356$.

IHAMBERLIN, W. J., 1939. The Bark and Timber Beetles of North America. Corvallis: Oregon State College Cooperative Association.

THAMBERLin, W. J. 1958. The Scolytoidea of the Northwest. Corvallis: Oregon State College Press.

HARARAS, C., 1960. Recherches sur la biologie de Pityogenes chalcographus L. Journal Forestier Suisse, 1960: 24-42, 82-97.

XHARARAS, C., 1962. Étude Biologique des Scolytidae des Coniferes. Paris: Lechevalier.

HARARAS, C., 1966. Recherches sur l'attractivité chez les Scolytidae. Étude sur l'attractivité sexuelle chez Carphoborus minimus Fabr. Coléoptère Scolytidae typiquement polygame. Comptes Rendus, Academie des Sciences, Paris. Series D, 262: 24922495. 
CHARARAS, C., 1968. Recherches sur le comportment sexuel de Pityokteines spinidens Reit. (Coléoptère Scolytidae polygame et étude des facteurs qui agissent sur le pouvoir attractif du mâle à l'égard de la femelle. Comptes Rendus, Academie des Sciences, Paris, Series D, 267: 18521855.

CHARARAS, C., 1969. Recherches sur l'attractivité sexuelle de Phloeosinus bicolor Brul., Coléoptère Scolytidae parasite spécifique des Cupressinae. Comptes Rendus, Academie des Sciences, Paris. Series D, 268: 1080-1083.

CHARARAS, C., 1979. Ecophysiologie des Insectes Parasites des Forets. Paris: published by the author.

CHARARAS, G. \& M'SADDA, K., 1970. Attraction chimique et attraction sexuelle chez Orthotomicus erosus Woll., (Coléoptère, Scolytidae). Comptes Rendus, Academie des Sciences, Paris, Series D, 271: 1904-1907.

CHARARAS, C, JUSTER, M. \& BALMAIN-OLIGO, N., 1968. Recherches sur le stimulus attractif de Cedrus libani Barr. vis-à-vis de Phloeosinus cedri Schedl (Coléoptère Scolytidae). Bulletin de la Societé Zoologique de France, 93: 309 316.

CHODJAI, M., 1963. Étude écologique de Rugoscolytus mediterraneus Eggers (Col. Scolytidae) en Iran. Revue de Pathologie Végétale et d'Entomologie Agricole de France, 42: 139-160.

COLE, W. E., 1967. Sampling biologically in forest insect populations. Annals of the Entomological Society of America, fin: $860-861$.

COLE, W. E., 1973. Crowding effects among single-age larvae of the mountain pine beetle, Dendroctonus ponderasae (Coleoptera: Scolytidae). Environmental Entomology, 2: 285 293.

COOPER, M. E. \& STEPHEN, F. M., 1978. Parent adult reemergence in southern pine bectle populations. Environmental Entomology, 7: 574-577.

COSTER, J. E., 1970. Production of aggregating pheromones of re-emerged parent females of the southern pine beetle. Annals of the Entomological Society of America, 63: 1186-1187.

COULSON, R. N., MAYYASI, A. M., FOLTZ, J. L., HAIN, F. P. \& MARTIN, W. C., 1976. Resource utilization by the southern pine beetle, Dendroctonus frontalis (Coleoptera: Scolytidae). Canadian Entomologist, I08: 353-362.

COUlsON, R. N., FARGO, W. S., PUlley, P. E., POPE, D. N., RICHERSON, J. V. \& PAYNE, T. L., 1978. Evaluation of the re-emergence of parent adult Dendroctonus frontalis (Coleoptera: Scolytidae). Canadian Entomologist, 110: 475-486.

DeLEON, D., 1952. Insects associated wtih Sequoia sempervirens and Sequoia gigantea in California. Pan-Pacific Entomologist, 28: 75-92.

DEYRUP, M., 1981. Annotated list of Indiana Scolytidae (Coleoptera). Greal Lakes Entomologist, 14: 1-9.

DYER, E. D. A. \& TAYLOR, D. W., 1971. Spruce beetle brood production in logging slash and wind-thrown trees in British Columbia. Pacific Forest Research Centre, Canadian Forestry Service Information Report BC:-X-6;?.

EHRLIC.H, A. H. \& EHRLICH, P. R., 1978. Reproductive strategies in the butterflies: I. Mating frequency, plugging, and egg number. Journal of the Kansas Entomological Society, 51; 666- 697.

EMLEN, S. T., 1976. Lek organization and mating strategies in the bullfrog. Behavioral Ecology and Sociobiology, 1: 283-313.

EMIFN, S. T. \& ORING, L. W., 1977. Ecology, sexual selection, and the evolution of mating systems. Science, 197: $215-223$.

ENTWISTLE, P. F., 1964. Inbreeding and arrhenotoky in the ambrosia beetle Xyleborus compactus (Eichh. (Coleoptera: Scolytidae). Proceedings of the Royal Entomological Society of London (A), 39:83-88.

FFRRER, F. R. \& HOWER, A. A., 1975. Gamma radiation effects on the reproduction of the alfalfa weevil: II. Influence of mating sequence and length of confinement on sperm transfer and utilization. Turrialba, 25: 166-173.

FINNEGAN, R, J., 1967. Note on the biology of the pitted ambrosia beetle, Corthylus punctatissimus (Coleoptera: Scolytidae) in Ontario and Quebec. Canadian Entomologist, 99: 49-54.

FISHER, R. C., 1931. Notes on the biology of the large elm bark beetle, Scolytus destructor 01. Forestry, 5 : 120-131.

FOCKLER, C. E. \& BORDEN, J. E., 1972. Sexual behavior and seasonal mating activity of Trypodendron lineatum (Coleoptera: Scolytidae). Canadian Entomologist, 104: 1841-1853.

FRENCH, J. R. J. \& ROFPER, R. A., 1973. Patterns of nitrogen utilization between the ambrosia beetie Xyleborus dispar and its symbiotic fungus. Journal of Insect Physiology, 19: 593-605.

FUHRER, V. E., 198I. Jahreszeitliche Qualitätsschwankungen des Fichtenbastes (Picea excelsa Link) als Brutsubstrat für den Borkenkäfer Pilyogenes chalcographus L. (Col., Scolytidac). Zeitschrift für angewandte Entomologie, 91: 74-83.

GLESENER, R. R. \& TILMAN, D., 1978. Sexuality and the components of environmental uncertainty: Clues from geographical parthenogenesis in terrestrial animals. American Naturalist, 112:659-673.

GOEDEN, R. D. \& NORRIS, D. M., 1964. Some biological and ecological aspects of the dispersal fight of Scolytus quadrispinosus (Coleopterd: Scolytidae). Annals of the Entomological Society of America, 57: 743-749.

GOEDEN, R. D. \& NORRIS, D. M., 1965. Some biological and ecological aspects of ovipositional attack in Carya spp. by Scolytus quadrispinosus (Coleoptera: Scolytidae). Annats of the Eniomological Society of America, 58: $77 i \cdot 777$

GOSSARD, H. A., 1913. Orchard bark beetles and pin hole borers. Bulletin of the Ohio Agricultural Experiment Station no. 264: $68 \mathrm{pP}$.

GOUGER, R. J., YEARIAN, W. C. \& WILKINSON, R. C., 1975. Feeding and reproductive behavior of Ips aculsus. Florida Entomologist, 58: 221-229. 
GOYER, R. A. \& FINGER, C. K., 1980. Relative abundance and seasonal distribution of the major hymenopterous parasites of the southern pine beetle, Dendroctonus frontalis Zimmerman, on loblolly pine. Eni:ironmental Entomology, 9: 97-100.

GRAF, P., 1977. Ein Beitrag zur Biologie und Bekampfung von Hylesinus oleiperda F. (Coleopt., Scolytidae) auf Olive in der Tadla (Marokko). Zeitschrift für angewandte Entomologie, 83: 52-62.

GRAY, B., 1974. Sex ratio, relative size, and order of attack of adults of Hylurdrectonus araucariae (Coleoptera: Scolytidae). Annals of the Entomological Society of America, 67: 144-145.

GRAY, B. \& LAMB, K. P., 1975. Biology of Hylurdrectonus araucariae Schedl (Coleoptera: Scolytidae), a pest of hoop pin plantations in New Guinea. Bulletin of Entomological Research, 65: 21-32.

GRUNER, L., 1974. Biologie et dégâts d'Hexacolus guyanensis Schedl dans les plantations d'acajou rouge (Srevietenia macrophylla King., Meliaceae) en Guadeloupe (Coleoptera: Scolytidae). Annales des Sciences Forestiéres, 31: 111-128.

GUREVITZ, E., 1976. Contribution a l'étude des Scolytidae. II. Dynamique des populations du scolyte mediterraneen Scolytus (Rugoscolytus) mediterraneus Eggers en Israel. Annales de Zoologie-Écologie animale, 8 : $53-68$.

HADORN. C., 1933. Recherches sur la morphologie, les stages évolutifs et l'hivernage du bostryche liseré (Xyloterus lineatus Oliv.). Supplément aux Organes de la Société Forestière Suisse, Bern, $11: 1-120$.

HAMILTON, W. D., 1967. Extraordinary sex ratios. Science, 156: 477-488.

HAMILTON, W. D., 1971. Geometry for the selfish herd. Journal of Theoretical Biology, 31: 295-311

HAMILTON, W. D., 1979. Wingless and fighting males in fig wasps and other insects. In M. S. \& N. A. Blum (Eds), Sexual Selection and Reproductive Competition in Insects: 167-220. New York: Academic Press.

HAMILTON, W. D., 1980. Sex versus non-sex versus parasite. Oikos, 35: 282-290

HEDLIN, A. F. \& RUTH, D. S., 1970. A Douglas-fir twig mining beetle, Pityophthorus orarius (Coleoptera: Scolytidae). Canadian Entomologist, 102: 105-108.

HERFS. A., 1959. Uber den Steinnussborkenkäfer Coccotrypes dactyliperda F. Anzeiger für Schädlingskunde, 32: 1-4.

HODGES, J. D. \& PICKARD, L. S., 1971. Lightning in the ecology of the southern pine beetle. Dendroctonus frontalis (Coleoptera: Scolytidae). Canadian Entomologist, 103: 44-51.

HOPKINS, A. D., 1909. Contributions toward a monograph of the scolytid beetles. I. The genus Dendroctonus. $L$. S. D. A. Bureau of Entomology Technical Series, 17, part 1: $164 \mathrm{pp}$.

HOPPING, G. R., 1963. The natural groups of species in the genus Ips DeGeer (Coleoptera: Scolytidae) in North America. Canadian Entomologist, 95: 508-516.

HOSKING, G. P. \& KNIGHT, F. B., 1976. Investigations on the life history and habits of Pityokteines sparsus (Coleoptera: Scolytidae). Life Sciences and Agricultural Experiment Station University of Maine at Orono Technical Bulletin no. $81: 37 \mathrm{pp}$.

HUGHES, A. L., 1979. Reproductive behavior and sexual dimorphism in the white-spotted sawyer Monochamus scutellatus (Say). Coleopterists Bulletin, 33: $45-47$.

ISRAELSON, G., 1980. Taxonomical and nomenclatural notes on some Canarian Coleoptera. Vieraea, 9: $183-210$

JANZEN, D. H., 1972. Association of a rainforest palm and seed-eating beetles in Puerto Rico. Ecology, 53: 258. 261.

JAYNES, H. A. \& GODWIN, P. A., 1957. Sterilization of the white-pine weevil (Pissodes strobi Peck) with gamma radiation. Journal of Economic Entomology, 5(): 393-395.

JOVER, H., 1952. Note préliminaire sur la biologie des Platypodidae de Basse-côte d'Ivoire. Reiue de Pathologie Végétale et Entomologie Agricole de France, 31: 73-81.

$\mathrm{KABE}$, M., 1954. Illustrations of galleries of bark-beetles (Scolytidae and Platypodidae). (Publ, in 2 parts; both in Japanese and English.) Maebashi Regional Forest Office.

KABE, M., 1955. Studies on the galleries of bark beetles and ambrosia beetles in Japan. (In Japanese, some English captions.) Maebashi Regional Forest Office.

KABIR, A. K. M. F. \& GIESE, R. L., 1966. The Columbian timber beetle, Corthylus columbianus (Coleoptera: Scolytidae). I. Biology of the beetle. Annals of the Entomological Society of America, 59: 894-902.

KALSHOVEN, L. G. E., 1958. Studies on the biology of Indonesian Scolytoidea. 4. Data on the habits of Scolytidae. First part. Tijdschrift voor Entomologie, 101: 157180.

KINZER, H. G. \& REEVES, J. M., 1976. Biology and behavior of cone beetles of ponderosa pine and southwestern white pine in New Mexico. New Mexico Agricultural Experiment Station Bulletin, 641: 1-28.

KINZER, H. G., RIDGILL, B. J. \& WATTS, J. G., 1970. Biology and cone attack behavior of Conophthorus ponderosae in southern New Mexico (Coleoptera: Scolytidae). Annals of the Entomological Society of America, f33: $795-798$

KI.AUSER, O., 1954. Ein Beitrag zur Kenntnis des Kupferstechers (Pityogenes chalcographus L.). In G. Wellenstein (Ed.), Die grosse Borkenkäferkalamitat in Südwestdeutschland 1944-1951: 285-299.

KOK, L. T., 1979. Lipids of ambrosia fungi and the life of mutualistic beetles. In L. R. Batra (Ed.), Insect-Fungus Symbiosis: Vutrition, Mutualism, and Commensalism: 33-52. Montclair: Allanheld, Osmun \& Company.

KUDON, L. H. \& BERISFORD, C. W., 1980. Influence of brood hosts on host preferences of bark beetle parasites, Vature, 283: 288290.

LEKANDFR, B., 1968. Scandinavian bark beetle larvae. Description and classification. Department of Forest Zoology, Royal College of Forestry, Stockholm, Research, Votes, 4: 1-186. 
LLOYD, D. G., 1980. Bencfits and handicaps of sexual reproduction. Evolutionary Biology, 13: 69111.

MANGAN, R. L., 1979. Reproductive behavior of the cactus fly, Odontoloxozus longicornis, male territoriality and female guarding as adaptive strategies. Behavioral Ecology and Sociobiology, 4: 265-278.

MASSEY, C. L. \& WYGANT, N. D., 1954. Biology and control of the Englemann spruce beetle. U. S. D. A. Circular $944: 35 \mathrm{pp}$.

MATTSON, W. J., 1980a. Herbivory in response to plant nitrogen content. Annual Reniew of Ecology and Systematics, 11: 119-161.

MATTSON, W. J., 1980b. Cone resources and the ecology of the red pine cone beetle, Conophthorus resinosae (Coleoptera: Scolytidae). Annals of the Entomological Scoiety of America, 73: 390-396.

MAYNARD SMITH, J., 1978. The Evolution of Sex. Cambridge: Cambridge University Press.

MCCAMBRIDGE, W. F., 1969. Spermatoza in unemerged female mountain pine beetles, Dendroctonus ponderosae Hopkins. Proceedings of the Entomological Society of Ontario, 100: 168170.

MoGHEHEY, J. H., 1968. 'Territorial behavior of bark-beetle males. Canadian Entomologist, 100: 1153.

McGHEHEY, J. H. \& NAGEL, W. P., 1969. The biologies of Pseudohylesinus tsugae and P. grandis (Coleoptera: Scolytidae in western hemlock. Canadian Entomologist, 101:269 279.

MCLEAN, J. A.\& BORDEN, J. H, 1975. Gnathotrichus sulcatus attack and breeding in freshly sawn lumber. Journal of Economic Entomology, 68: 605-606.

MCLEAN, D. B. \& GIESE, R. L., 1967. The life history of the ambrosia beetle Xyloterinus politus (Coleoptera: Scolytidae: Canadian Entomologist, 99: 285 299.

McMULI.EN, L. H. \& ATKINS, M. D., 1959. I.ife-history and habits of Scolytus tsugae (Swaine) (Coleoptera: Scolytidae; in the interior of British Columbia. Canadian Entomologist, 91: 416-426.

McMULI.EN, L. H. \& ATKINS, M. D., 1961. Intraspecific competition as a factor in the natural control of the Douglas-fir beetle. Forest Science, 7: 197-203.

McMULLEN, L. H. \& ATKINS, M. D., 1962. Life-history and habits of Scolytus unispinosus Leconte (Coleoptera: Scolytidae) in the interior of British Columbia. Canadian Entomologist, 94: 17-25.

McMULLEN, I. H., KING, E. W. \& SHENEFEI,T, R. D., 1955. The oak bark beetle. Pseudopityophthorus minutissimus (Zimm.) (Coleoptera, Scolytidac) and its biology in Wisconsin. Canadian Entomologist, 87: 491- 495.

MiNELLL, S. \& SOUTHWOOD, T. R. E., 1978. The role of nitrogen in the development of insect/plant relationships. In J. Harborne (Ed.), Biochemical Aspects of Plant and Animal Coevolution: 77-98. London: Academic Press.

MERR IL.I., W. \& COWLING, E. B., 1966. Roles of nitrogen in wood deterioration: amounts and distribution of nitrogen in tree stems. Canadian Journal of Botany, 44: $1555 \cdots 1580$.

MICHELSEN, A., 1966. The sexual behavior of some longhorned beetles. (Col., Cerambycidae). Entomologiske Meddelelser, 34: 329355.

MIZELL, R. F. \& NEBEKER, T. E., 1978. Estimating the developmental time of the southern pine beetle Dendroctomus frontalis as a function of field temperatures. Environmental Entomology, 7: 592-595.

NAKASHIMA, T., 1975. Several types of mycetangia found in platypodid ambrosia beetles (Coleoptera Platypodidae). Insecta Matsumurana new series, 7: 1-69.

NIJHOLT, W. W., 1970. The effect of mating and the presence of the male ambrosia beetle, Trypodendron lineatum, on "secondary" attraction. Canadian Entomologist, 102: 894-897.

NIJHOI.T, W. W., 1973. The effect of male Trypodendron lineatum (Coleoptera scolytidae) on the response of field populations to secondary attraction. Canadian Entomologist, 105: 583-590.

NOBUCHI, A., 1969. A comparative morphological study of the proventriculus in the adult of the superfamily Scolytoidea (Coleoptera). Bulletin of the Gouernment Forest Experiment Station, 224:39-110.

NOBUCHI, A., 1971. Studies on Scolytidae IX (Coleoptera). Key to the subfamilies, tribes and genera of Japan. Bulletin of the Government Forest Experiment Station, 238: 149-164.

NOBUCHI, A., 1972. The biology of Japanese Scolytidae and Platypodidae. Review of Plant Protection Research, 5: $61-75$.

NOBUCHI, A., 1980. The ambrosia beetles of the subfamily Scolytoplatypinae (Coleoptera, Scolytidae) in Japan. Kontyu, 48: 42-52.

NOBUC.HI, A., 1981. Studies on Scolytidae (Coleoptera) XXI. Three new genera and species from Japan Kontvû, 49:12 18.

NORD, J. G, 1972. Biology of the Columbian timber beetle, Corthylus columbianus (Coleoptera: Scolyridae), in Georgia. Annals of the Entomological Society of America, 65: 350-3.58.

NORRIS, D. M., 1975. Chemical interdependence among $X_{y}$ leborus spp. ambrosia beetles and their symbiotic microbes. Material und Organismen, 3: 479-488.

NORRIS, D. M., 1979. The mutualistic fungi of Xyleborini beetles. In L. R. Batra (Ed.), Nutrition, Mutualism, and Commensalism: 53-63. Montclair: Allanheld, Osmun \& Company.

NORRIS, D. M. \& CHU, H. M., 1970. Nutrition of Xyleborus ferrugineus. II. A holidic diet for the aposymbiotic insect. Annals of the Entomological Society of America, 63: 1142-1145.

OESTER, P. T. \& RUDINSKY, J. A., 1975. Sound production in Scolytidae: stridulation by "silent" Ips bark beetles. Zeitschrift für angewandie Entomologie, 79: 421-427.

OESTER, P. T., RYKER, L. C. \& RUDINSKY, J. A., 1978. Complex male premating stridulation of the bark beetle Hylurgops rugipennis (Mann.). Coleopterists Bultetin, 32: 93-98.

OESTER, P. T., RUDINSKY, J. A. \& RYKER, L. C., 1981. Olfactory and acoustic behavior of Pseudohylesinus nebulosus (Coleoptera: Scolytidae) on Douglas-fir bark. Canadian Entomologist, 113: 645-650. 
OHMART, C. P., 1979. The within-tree distribution of Ips paraconfusus (Coleoptera: Scolytidae) and its insect associates in Monterrey pine (Pinus radiata). Annals of the Entomological Society of America, 72: 607-609.

ORIANS, G. H., 1969. On the evolution of mating systems in birds and mammals. American Naturalist, 103: 589-603.

PARKER, G. A., 1970. Sperm competition and its evolutionary consequences in insects. Biological Review, 45: $525-576$.

PARKER, G. A., 1974. Courtship persistance and female-guarding as male time investment strategies. Behaviour, 48: $157-184$.

PAYNE, R. B. \& PAYNE, K., 1977. Social organization and mating success in local song populations of village indigobirds, Vidua chalybeata. Zeitschrift für Tierpsychologie, 45: 113-173.

PETTY, J. L., 1977. Bionomics of two aspen bark beetles, Trypophloeus populi and Procryphalus mucronaius (Coleoptera: Scolytidae). Great Basin Vaturalist, 37: 105-127.

REID, R. W., 1955. The bark beetle complex associated with lodgepole pine slash in Alberta. Part I - notes on the biologies of some Scolytidae attacking lodgepole slash. Canadian Entomologist, 87: 311-323.

REID, R. W., 1958. The behavior of the mountain pine beetle, Dendroctonus monticolae Hopk., during mating, egg laying, and gallery construction. Canadian Entomologist, 90: 505-509.

REXRODE, C. O., 1969. Seasonal development and habits of Pseudopityophthorus spp. (Coleoptera: Scolytidae) in southern Ohio. Canatian Entomologist, 101:306-313.

REXRODE, C. O., KULMAN, H. M. \& DORSEY, C. K., 1965. Bionomics of the bark beetle Pseudopityophthorus pruinosus with special reference to its role as a vector of oak wilt, Ceratocystis fagacearum. Journal of Economic Entomology, 58: 913-916.

ROBERTS, H., 1960. Trachyosius ghanaensis Schedl (Col., Platypodidae) an ambrosia beetle attacking wawa, Triplochiton scleroxylon K. Schum. Technical Bulletin of the West Africa Timber Borer Research Unit, no. 3: $17 \mathrm{pp}$.

ROBERTS, H., 1976. Observations on the biology of some tropical rain-forest Scolytidae (Coleoptera) from Fiji I. Subfamilies-Hylesininae, Ipinae (excluding Xyleborini). Bulletin of Entomological Research, 66: 373-388.

ROCKWOOD, L. P., 1926. The clover root borer. U. S. D. A. Department Bulletin 1426: 48pp.

ROEPER, R., TREEFUL, L. M., O'BRIEN, K. M., FOOTE, R. A. \& BUNCE, M. A., 1980. Life history of the ambrosia beetle Xyleborus affinis (Coleoptera: Scolytidae) from in vitro culture. Great Lakes Entomologist, 13: 141-144.

ROLING, M. P. \& KEARBY, W. H., 1974. Life stages and development of Monarthrum fascialum (Coleoptera: Scolytidae) in dying and dead oak trees. Canadian Entomologist, 106: 1301-1308.

ROZHKOV, A. S., 1970. Family Ipidae. In A. S. Rozhkov (Ed.), Pests of Siberian Larch: 128-158. Jerusalem: Israeli Program for Scientific Translation (translated from the Russian).

RUCKES, H., 1958. Some observations on the Monterrey pine cone beetle Conophthorus radiatae Hopkins (Coleoptera: Scolytidae). Annals of the Entomological Society of America, 51: 214-215.

RUDINSKY, J. A., 1969. Masking of the aggregating pheromone in Dendroctonus pseudotsugae Hopk. Science, 166: $884-885$.

RUDINSKY, J. A., MORGAN, M. E., LIBBEY, L. M. \& MICHAEL, R. R., 1973. Sound production in Scolytidae: 3-methyl-2-cyclohexen-1-one released by the female Douglas-fir beetle in response to male sonic signal. Environmental Entomologv, 2: 505-509.

RUDINSKY, J. A., OESTER, P. T. \& RYKER, L. C., 1978. Gallery initiation and stridulation of the polygamous spruce bark beetle, Polygraphus rufipennis. Annals of the Entomological Society of America, 7l:317-321.

RUDINSKY, J. A. \& RYKER, L. C., 1976. Sound production in Scolytidae: rivalry and premating stridulation of male Douglas-fir beetles. Journal of Insect Physiology, 22: 997-1003.

RUDINSKY, J.A. \& VALLO, V., 1979. The ash bark beetles Lepersinus fraxini and Hylesinus oleiperda: stridulatory organs, acoustic signals, and pheromone production. Zeitschrift für angewandte Entomologie, 87: 417429.

RUDINSKY, J. A., VALLO, V. \& RYKER., L. C., 1978. Sound production in Scolytidae: attraction and stridulation of Scolytus mali (Col. Scolytidae). Zeitschrifl für angewandte Entomologie, 86: 381-391.

RUDINSKY, J. A. \& VERNOFF, S., 1979. Evidence of a female-produced aggregative pheromone in Leperisinus californicus Swaine (Coleoptera: Scolytidae). Pan-Pacific Entomologist, 55: 299-303.

RUSSO, G., 1938. VI. Contributo alla conoscenza dei Coleotteri Scolitidi, Fleotribo: Phleotribus scarabaeoides (Bern.) Fauv. Parte seconda: Biografia, simbionta, danni e lotta. Bolletino del R. Laboratorio di Entomologia Agraria di Portici, 2: 3419.

RYKER, L. C. \& RUDINSKY, J. A., 1976a. Sound production in Scolytidae: acoustic signals of male and female Dendroctomus valens LeConte. Zeitschrift für angewandte Entomologie, 80: 113-118.

RYKER, L. C. \& RUDINSKY, J. A., 1976b. Sound production in Scolytidae: aggressive and mating behavior of the mountain pine beetle. Annals of the Entomological Society of America, 69: 677-680.

SAFRANYIK, L. \& JAHREN, R., 1970. Host characteristics, brood density and size of mountain pine beetles emerging from lodgepole pine. Canadian Forestry Service, Bi-monthly Research Notes, 26: 35-36.

SAHOTA, T.S. \& THOMSON, A.J., 1979. Temperature induced variation in the rates of reproductive processes in Dendroctonus rufipennis (Coleoptera: Scolytidae): a new approach to detecting changes in population quality. Canadian Entomologist, 111: 1069-1078.

SALONEN, K., 1973. On the life cycle, especially on the reproductive biology of Blastophagus piniperda $\mathrm{L}$. (Coleoptera: Scolytidae). Acta Forestalia Fennica, 127: 72 pp. 
SAlONEN, K., PUlliainen, E. \& KOPONEN, M., 1968. Sex ratios in Blastophagus piniperda L. (Col., Scolytidae in Finland. Annales Entomologici Fennici, 34: 31-37.

SCHAEFER, C. H., 1972. Life history of Conophthorus radiatae (Coleoptera: Scolytidae) and its principal parasite, Cephalonomia utahensis (Hymenoptera: Bethylidae). Annals of the Entomological Saciety of America, 55: 569-577.

SCHEDL, K. E., 1958. Breeding habits of arboricole insects in Central Africa. Proceedings of the 10th International Congress of Entomology, Monireal, 1: 183-197.

SCHEDL, K. E., 1959. Scolytidae und Platypodidae Afrikas. Revista de Entomologia de Moçambique. 2: $357-422$.

SCHEDL, K. E., 1960. Scolytidae und Platypodidae Afrikas. Revista de Entomologia de Mogambique. 3: 75-154.

SCHEDL, K. E., 1961. Scolytidae und Platypodidae Afrikas. Revista de Entomologia de Mocambique. 4: 335.742.

SCHEDL, K. E., 1962. Scolytidae und Platypodidae Afrikas. Revista de Entomologia de Mogambique. 5: 1-1352.

SCHEDL, K. E., 1972. Monographie der Familie Platypodidae (Coleoptera). Den Haag: W. Junk.

SCHENK, J. A. \& BENJAMIN, D. M., 1969. Notes on the biology of Ips pini in eastern Wisconsin jack-pine forests. Annals of the Entomological Society of America, 62: 480-485.

SCHMITZ, R. F., 1972. Behavior of Itps pini during mating, oviposition, and larval development (Coleoptera: Scolytidae). Canadian Entomologist, 104: 1723-1728.

SCHOONHERR, J., 1970. Evidence of an aggregating pheromone in the ash-bark beetle, Leperisinus fraxini (Coleoptera: Scolytidae). Contributions from the Boyce Thomson Institute, 24 : 305-307.

SCHWERDTFEGER, F, 1929. Ein Beitrag zur Fortpflanzungsbiologie des Borkenkäfers Pityogenes chalcographus L. Zeitschrift für angewandte Entomol:gie, 15: 335427.

SEITNER, M., 1923. Beobachtungen und Erfahrungen aus dem Auftreten des achtzähnigen Fichtenborkenkäfers Its typographus L. in Oberösterreich und Steiermark in den Jahren 1921 und 1922. Zentralblatt fiur das gesamte Forstzeesen, 49: 1-11, 149-162, 270 277. (Cited in Schwerdtfeger, 1929, and Annila, 1971: not seen.)

SEI.ANDER, R. K., 1972. Sexual selection and dimorphism in birds. In B. Campbell (Ed.), Sexual Selection and the Descent of Man: 180-230. Chicago: Aldine Press.

SIMPSON, L. J., 1929. The seasonal history of Polygraphus rufitennis Kirby. Canadian Entomologist, 61: 146-151.

SIVIXSKI, J., 1978. Intrasexual aggression in the stick insects Diapheromera veliei and D. covillea and sexual dimorphism in the Phasmatodea. Psyche, 85: 395405.

SIVINSKI, J., 1980. The effects of mating on predation in the stick insect Diapheromera veliei Walsh (Phasmatodea: Heteronemiidae). Annals of the Entomological Society of America, 73: 553-556.

SMITH, R. H., 1961. Red turpentine beetle. U. S, D. A. Forest Service Pest Leaflet, 55: 8 pp.

SMITH, R. H., 1975. Formula for describing effect of insect and host tree factors on resistance to western pine beetle attack. Journal of Economic Entomologv, 68: 841-844.

STE.NSETH, N.C., 1980. Spatial heterogeneity and population stability: some evolutionary consequences. Oikos, 35: $165 \cdot 184$.

STEWART, K. W., 1965. Observations on the life history and habits of Scierus annectens (Coleoptera: Scolytidae). Annals of the Entomological Society of America, 58: 924-927.

STURGLON, K. B., 1979. Monoterpene variation in ponderosa pine xylem resin related to western pine beetle predation. Evolution, 33: 803-814.

SWABY, J. A. \& RUDINSKY, J, A., 1976. Acoustic and olfactory behavior of Ips pini (Say) (Coleoptera: Scolytidae during host invasion and colonisation. Zeitschrift fur angewandte Entomologie, 81: 421-432.

SWAINE, J. M., 1911. Some insects from larch. Annual Report of the Entomological Sociely of Ontario, 41: 81.91.

SW AINE, J. M., 1918. Canadian bark beetles. II. $\Lambda$ preliminary classification with a account of the habits and means of control. Canada Department of Agriculture Entomology Branch Technical Bulletin, 14: $143 \mathrm{pp}$.

SWAINE, J. M., 1929. The biology of Canadian bark beetles. Canadian Entomologist, 61: 145-151.

TAKAGI, K. \& KANEKO, T., 1966. Biology of some scolytid ambrosia beetles attacking tea plants. V. Chromosome numbers and sex determination of tea root borer, Xyleborus germanus Blandford (Coleoptera: Scolytidae. Applied Entomology and Zoology, 1: 29-31.

TAKENOUCHI, Y. \& TAKAGI, K., 1967. A chromosome study of two parthenogenetic scolytid beetles. Annotationes Zoologicae Japonenses, 40: 105110.

THOMAS, J. B., 1961. The life history of Ips pini (Say) (Coleoptera: Scolytidae). Canadian Entomologist, 93: 384- 390 .

THOMSON, A. J. \& SAHOTA, T. S., 1981. Competition and population quality in Dendroctonus rufpennis (Colcoptera: Scolytidaci, Canadian Entomologist, 113:117-183.

TRAGARDH, I., 1930. Studies on the galleries of bark beetles. Bulletin of Entomological Research, 21: $469-480$.

TR IMBLE, F. M., 1924. Life history and habits of two Pacific coast bark beetles. Annals of the Entomological Society of America, 17:382 391 .

VERXER, J., 1964. Evolution of polygamy in the long-billed marsh wren. Evolution, 18: 252-261.

VERNER, J. \& WILLSON, M. F., 1966. The influence of habitats on mating systems of North American birds. Ecology, 47: 143 147.

VERYOFF, S. \& RLDINSKY, J. A., 1980. Sound production and pairing behavior of leperisinus californicus Swaine and L. oregonus Blackman (Coleoptera: Scolytidae) attacking Oregon ash. Zeischrift fiur angewandte Entomologie. 90: 58-74.

VITÉ,J. P., BAKKE, A.\& RENWICK, J. A. A., 1972. Pheromones in Ips (Coleoptera: Scolytidae) : occurrence and production. Canadian Entomologist, 104: 1967-1975.

VITÉ, J. P. \& FRANCKE, W., 1976. The aggregation pheromones of bark beetles: progress and problems. Taturreissenschaften, 63: 550-555. 
WAAGE, J. K., 1973. Reproductive behavior and its relation to territoriality in Calopteryx maculata (Beauvois) (Odonata: Calopterygidae). Behaviour, 47: 240-256.

WAGNER, T. L., GAGNE, J. A., DORAISWAMY, P. C., COULSON, R. N. \& BROWN, K. W., 1979. Developmental time and mortality of Dendroctonus frontalis in relation to changes in tree moisture and xylem water potential. Environmental Entomology, 8: 1129-1138.

WAGNER, T. L., FELDMAN, R. M., GAGNE, J. A., COVER, J. D., COULSON, R. N. \& SCHOOLFIELD, R. M., 1981. Factors affecting gallery construction, oviposition, and reemergence of Dendroctonus frontalis in the laboratory. Annats of the Entomological Society of America, 74: 255-273.

WALKER, W. F., 1980. Sperm utilization strategies in non-social insects. American Naturalist, 115: 780-799.

WEBB, J. W. \& FRANKLIN, R. T., 1978. Infuence of phloem moisture on brood development of the southern pine beetle (Coleoptera: Scolytidae). Environmental Entomology, 7: 405-4l0.

WEBB, W. E. \& JONES, T., 1957. West African Timber Borer Research Unit Report, 1953-1955. Report of the West African Timber Borer Research Unit, 1953-1955. 44 pp.

WERNER, R. A., 1972. Aggregation behavior of the beetle I $p$ s grandicollis in response to insect-produced attractants. Fournal of Insect Physiology, 18: 1001-1013.

WHITE, T. C. R., 1978. The importance of a relative shortage of food in animal ecology. Oecologia (Berlin), 33: $71-86$.

WILKINSON, R. C., 1964. Attraction and development of $I p s$ bark beetle populations in artificially infested pine bolts exposed on fretowers and turntables in Florida. Florida Entomologist, 47: 57-64.

WILKINSON, R. C., MCCLELLAND, W. T., MURILLO, R. M. \& OSTMARK, E. O., 1967. Stridulation and behavior on two southeastern Ips bark beetles (Coleoptera: Scolytidae). Florida Entomologist, 50: 185-196.

WILLIAMS, G. C., 1966. Adaptation and Vatural Selection. Princeton: Princeton University Press.

WILliamS, G. C., 1975. Sex and Evolution. Princeton, N. J. : Princeton University Press.

WILLIAMSON, D. L., SCHENK, J. A. \& BARR, W. F., 1966. The biology of Conophthorus monticolae in northern Idaho. Forest Science, 12: 234-240.

WILSON, E. O., 1971. The Insect Sacieties. Cambridge, Massachusetts: Belknap Press of Harvard University Press.

WILSON, H. F., 1909. The peach-tree barkbeetle. U. S. D. A. Bureau of Entomology Bulletin, 68: 91-108.

WITANACHCHI, J. P., 1980. Evidence for pre-emergence mating among mature progeny of Ips grandicollis (Eichhoff), Journal of the Australian Entomological Society, 19: 93-100.

WITTENBERGER, J. F., 1979. The evolution of mating systems in birds and mammals. In P. Marler \& J. Vandenbergh (Eds.), Handbook of Behavioral Neurobiology: Social Behavior and Communication: 271-349. New York: Plenum Press.

WOOD, S. L., 1954a. A revision of North America Cryphalini (Scolytidae, Coleoptera). University of Kansas Science Bulletin, 36: 959-1089.

WOOD, S. L., 1954b. Bark beetles of the genus Carphoborus Eichhoff (Coleoptera: Scolytidae) in North America. Canadian Entomologist, 86: 502-526.

WOOD, S. L., 1957. Ambrosia beetles of the tribe Xyloterini (Coleoptera: Scolytidae) in North America. Canadian Entomologist, 89: 337-354.

WOOD, S. L., 1958. Bark beetles of the genus Pityborus Blackman (Coleoptera: Scolytidae). Great Basin Naturalist, 18: $46-56$.

WOOD, S. L., 1960. New records and species of Scolytidae (Coleoptera) from western North America. Great Basin Naturalist, 20: 59-69.

WOOD, S. L., 1961. New species of bark beetles (Coleoptera: Scolytidae), mostly Mexican. Part VI. Great Basin Naturalist, $21: 87-107$.

WOOD, S. L., 1961. A key to the North American genera of Scolytidae. Coleopterist's Bulletin, 15: 41-48.

WOOD, S. L., 1963. A revision of the bark beetle genus Dendroctonus Erichson (Coleoptera: Scolytidae). Great Basin Naturalist, 23: $1-117$

WOOD, S. L., 1965. The genus Eupagiocerus Blandford (Scolytidae: Coleoptera). Great Basin Naturalist, 25: 31-35.

WOOD, S. L., 1967. New records and species of neotropical bark beetles (Scolytidae: Coleoptera), part II. Great Basin , Vaturalist, 30: 119-141.

WOOD, S. L., 1968. A key to species of the Cnesinus LeConte (Coleoptera: Scolytidae) of North and Central America. Great Basin Vaturalist, 28: 88110.

WOOD, S. L., 1969a. New records and species of neotropical bark beetles (Scolytidae: Coleoptera) part IV Brigham Young Unizersity Science Bulletin, Biological Series, 10(2): 46 pp.

WOOD, S. L., 1969b. Additions to the horned bark beetle genus Cactopinus Schwarz (Scolytidae: Coleopterists Bulletin, 23: 42-5I.

WOOD, S. L., $197 \mathrm{la}$. New records and species of neotropical bark beetles (Scolytidae: Coleoptera) part V. Brigham Young Lniversity Science Bulletin, Biological Series, 15(3): $54 \mathrm{pp}$.

WOOD, S. I., 197 lb. New records and species of American Platypodidae (Coleoptera). Great Basin. Valuralist, 31: 243-253.

WOOD, S. L., 1973. On the taxonomic status of Platypodidae and Scolytidae (Coleoptera). Great Basin Vaturalist, 33: 77-90.

WOOD, S. L., 1974. New species of American bark beetles (Scolytidae: Coleoptera). Brigham Young University Science Bulletin, Biological Series, 19(3):67 pp. 
WOOD, S. L., 1977. Introduced and exported American Scolytidae (Coleoptera). Great Basin . Vaturalist, 37: 67.74

WOOD, S. L., 1978. A reclassification of the subfamilies and tribes of Scolytidue (Coleoptera). Annales de la Sociebe entomologique de France (Aoureau Series) 14: 95-122.

WOOD, S. I.., 1980. New genera and new generic synonymy in Scolytidae (Coleoptera). Great Basin Naturalist, 40: $89-97$.

WOOD, S. L., 1982. The bark and ambrosia beetles of North and Central America (Coleoptera: Scolytidae), a taxonomic monograph. Great Basin Vaturalist Momoirs, 6: I 1359.

WRIGHT, L. C., BFRRYMAN, A. A. \& GURUSIDDAIAH, S., 1979. Host resistance to the fir engraver beetle, Scolytus ventralis (Coleoptera: Scolytidae), 4. Effect of defoliation on wound monoterpene and inner bark carbohydrate concentrations. Canadian Entomologist, 111: 1255-1262.

YU, C. C. \& TSAO, C. H., 1967. Gallery construction and sexual behavior in the southern pine beetle, Dendroctonus frontalis Zimm. (Coleoptera: Scolytidae). Journal of the Georgia Entomotogical Society. 2: 95-98. 